\title{
"For your ears only" : quality of telephone triage at out-of-hours centres in the Netherlands
}

Citation for published version (APA):

Derkx, H. P. T. (2008). "For your ears only" : quality of telephone triage at out-of-hours centres in the Netherlands. [Doctoral Thesis, Maastricht University]. Maastricht University. https://doi.org/10.26481/dis.20080618hd

Document status and date:

Published: 01/01/2008

DOI:

10.26481/dis.20080618hd

Document Version:

Publisher's PDF, also known as Version of record

\section{Please check the document version of this publication:}

- A submitted manuscript is the version of the article upon submission and before peer-review. There can be important differences between the submitted version and the official published version of record.

People interested in the research are advised to contact the author for the final version of the publication, or visit the DOI to the publisher's website.

- The final author version and the galley proof are versions of the publication after peer review.

- The final published version features the final layout of the paper including the volume, issue and page numbers.

Link to publication

\footnotetext{
General rights rights.

- You may freely distribute the URL identifying the publication in the public portal. please follow below link for the End User Agreement:

www.umlib.nl/taverne-license

Take down policy

If you believe that this document breaches copyright please contact us at:

repository@maastrichtuniversity.nl

providing details and we will investigate your claim.
}

Copyright and moral rights for the publications made accessible in the public portal are retained by the authors and/or other copyright owners and it is a condition of accessing publications that users recognise and abide by the legal requirements associated with these

- Users may download and print one copy of any publication from the public portal for the purpose of private study or research.

- You may not further distribute the material or use it for any profit-making activity or commercial gain

If the publication is distributed under the terms of Article $25 \mathrm{fa}$ of the Dutch Copyright Act, indicated by the "Taverne" license above, 
"For your ears only"

Quality of telephone triage at out-of-hours centres in the Netherlands

Hay Derkx 
"For your ears only". Quality of telephone triage at out-of-hours centres in the Netherlands

Department of General Practice, University of Maastricht, The Netherlands.

The study presented in this thesis was funded by: Medicinfo; $C Z$ and VGZ, both Health Insurance Organisations, and the VVAA.

Cover design and thesis layout: Saskia Wasser, Medicinfo.

ISBN: 978-90-9023066-5

(C) 2008 Hay Derkx 


\title{
"For your ears only"
}

\author{
Quality of telephone triage at out-of-hours \\ centres in the Netherlands
}

\begin{abstract}
Proefschrift
ter verkrijging van de graad van doctor aan de Universiteit Maastricht, op gezag van de Rector Magnificus, Prof. mr. G. P. M. F. Mols, volgens het besluit van het College van Decanen, in het openbaar te verdedigen op woensdag 18 juni 2008 om 16.00 uur door Hay P. Th. Derkx
\end{abstract}


Promotor

Prof. dr. J. A. Knottnerus

Co-promotores

Dr. JJ. Rethans

Dr. Ir. A. M .M. Muijtjens

Beoordelingscommissie

Prof. dr. J. F. M. Metsemakers (voorzitter)

Dr. J. van Dalen

Prof. dr. J. de Haan (Universitair Medisch

Centrum Groningen)

Mw. dr. Y. D. van Leeuwen

Prof. dr. C. P. M. van der Vleuten 


\section{Contents}

Telephone triage past and present 11

New methodology for using incognito standardised 27

patients for telephone consultation in primary care

Assessing communication skills of clinical call handlers

working at an out-of-hours centre. The development

of the RICE rating scale

Quality of clinical aspects of call handling at Dutch out-of-hours centres

Quality of communication during telephone triage at

Dutch out-of-hours centres

"Quod scripsi, scripsi". The quality of the report of

telephone consultations at Dutch out-of-hours centres

General discussion

Summary

Samenvatting

Dankwoord

Curriculum vitae

Appendix

RICE-communication rating list

HAAK-communicatie scorelijst 
Voor alle triagisten die dagelijks voor een schier onmogelijke taak staan.

"Give them the tools and they will finish the job."

Vrij naar Winston Churchill, 1941 
Chapter 1

Telephone triage past and present 


\section{Introduction}

Patients worldwide now expect medical advice over the telephone for a variety of medical problems at any time of the day or night. To be able to provide adequate 24/7 hour medical care general practitioners in many countries started out-of-hours primary care service from large centres (1). At these out-of-hours centres the calls are handled by doctors, physician assistants or nurses who make decisions about the urgency of clinical problems and the care required (2). The process in which both the urgency and the care required for incoming calls is determined, is called telephone triage. This is an important part of care provided by an out-of-hours centre, and proves to be an area with an element of medical risk. Both patients and primary care providers frequently question the quality of the telephone triage (3-12).

\section{History of triage}

The word triage is derived from the French word "trier" which means "to sort". The original meaning of triage was prioritisation of victims of war and was related primarily to logistical problems (13). The Greeks and Romans triaged their wounded soldiers near the battlefield and brought them to ships or hospitals for further care (14). It was the French doctor Dominique-Jean Larrey (1766-1842) who introduced the concept of triage in the military history of war (1518). He served as a surgeon in Napoleon's army in many battles. He placed "hôpitaux ambulants" (Figure 1) and "ambulances volantes" alongside the battlefield so he could treat injured soldiers as close as possible to where they were found. His definition of triage was: "The severely wounded soldiers must be treated first, independent of their military rank. Otherwise, they will not survive. The less severely wounded must wait until the severely wounded have been treated. The lightly wounded soldiers should be treated in hospitals further away from the battlefield".

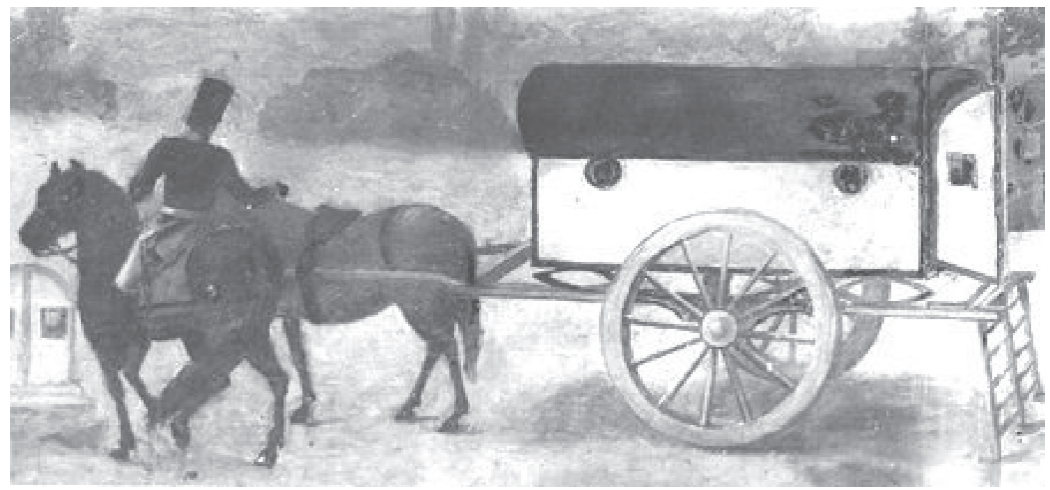

Figure 1: Ambulance volante 
Until doctor Larrey started to apply the system of triage, wounded soldiers waited an uncertain fate. The majority were transported to a hospital some time after their injuries occurred and on arrival had to wait before they were treated (19).

The principal of triaging the wounded is still accepted as the most efficient method of coordinating medical care for large numbers of casualties of war or natural disasters (20). In order to triage the wounded the following questions must be answered:

1. the diagnosis: how serious are the injuries?

2. the prognosis: what are the chances of survival?

3. the logistics: what options are available for transport?

Nowadays in the same way triage is applied to manage the flow of patients and to minimise risks while they wait for definitive treatment (21). Thus the objective of triage is to determine the severity of a medical problem, the type of care required and where and by whom this care should be provided.

\section{Medical care over the telephone}

Thomas Bell (Boston, USA) invented the telephone. On 10 March 1876 he called his assistant Thomas Watson with a machine that consisted of a wooden stand, a cup with acid solution, a funnel and a few copper wires, connected to a source of electricity (Figure 2). They did not appreciate then the impact that this invention would have throughout the world a hundred years later.
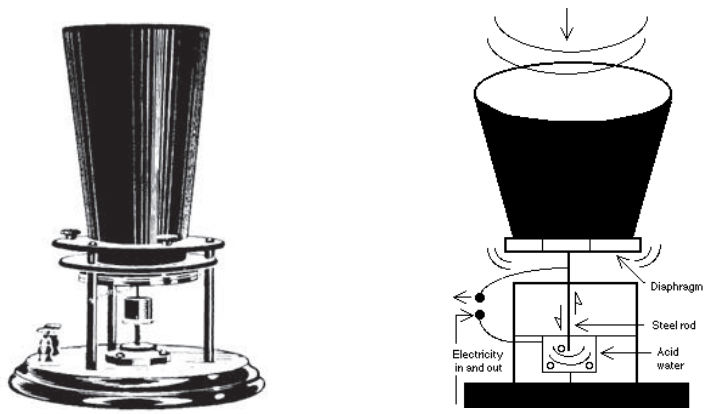

Figure 2: First telephone, invented by Thomas Bell in 1876

The first documented telephone consultation between a general practitioner and one of his patients dates back to 1879 (22):

"An anxious mother who, convinced that her baby had the croup, called the infant's grandmother for assistance. The latter, in turn, telephoned the family doctor at midnight and "told him the terrible news". Perhaps because of the lateness of the hour, the doctor asked 
to be put in telephonic communication with the anxious mamma.

'Lift the child to the telephone,' he commanded, 'and let me hear it cough.' Both mother and child complied. 'That's not the croup,' the doctor declared, and declines to leave his house on such small matters. He advised grandmamma also to stay in bed; and all anxiety quieted, the trio settled down happily for the night." .

Since the introduction of the telephone patients have been able to call a doctor or nurse for medical advice from almost anywhere in the world.

An important characteristic of triage over the telephone is the inability to see the patient. The call handler must compensate for the lack of visual contact by building a picture of the physical and mental condition of the patient (23-24). The application of telemedicine proves to become an important tool in the provision of medical service over the telephone. Visual contact and even physiological measurements by remote monitoring or camera equipment enables additional information to be included in decision making (25-30).

Medical call centres not only provide medical services focused on emergency care to patients. Some centres help to improve the accessibility of health care in general for example in countries where patients otherwise have to travel long distances to visit a doctor. Other centres specialise in giving telephone advice for unwell children (3132 ), for pre- and post-operative care (33-36), following attendance at a hospital emergency department (37-38), to schedule consultations at an ophthalmology department (39), to support breastfeeding mothers (40), to advise patients with chronic disease, such as cystic fibrosis (41), rheumatoid arthritis, HIV and AIDS (43-44), cancer (45) or chronic heart failure (46).

In the Netherlands some organisations offer health care advice by telephone to their clients (47-50).

\section{The process of telephone triage}

In the Netherlands in 2007 about 95\% of the 16 million inhabitants have access to one of the 105 out-of-hours centres providing primary care services. The call handling at the out-of-hours centre is carried out by a physician assistant or nurse. The call handler is called a "triagist". As in face-to-face triage, telephone triage is the care process carried out to determine the degree of urgency of the clinical problem and the type of care required (2).

For this study an analysis of the process of telephone triage was made to identify critical moments during this process. This was done in analogy with the experiences with process analysis in many industrial organisations to identify errors that can be made during 
the execution of the process. Once identified recommendations can be studied to prevent these errors. This analysis of the process of telephone triage identified three phases: firstly the phase of information gathering followed by the phase of determining urgency and type of care required. In the third phase a report is written to document what has been discussed with the caller (Figure 3).

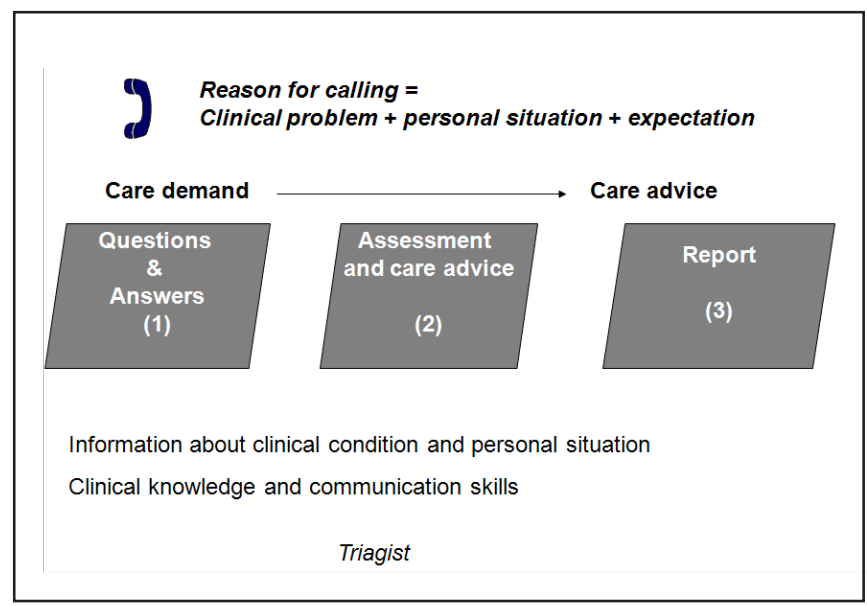

Figure 3: The three phases of the process of telephone triage

The first phase of telephone triage

In the first phase the triagist obtains the required information by asking questions concerning the clinical condition, the current personal situation and the expectation of the caller. To be able to assess the clinical condition the triagist asks questions about the complaint itself and its possible causes or consequences.

These questions follow a symptom oriented approach whereby careful history taking must compensate for the inability to see and to examine the patient.

Questions about the current personal situation of the patient help the triagist to appreciate how the patient is personally affected by the complaint (anxious, worried, uncertain), what his current circumstances are (patient is bedridden, leaving on holiday the following day) and his expectations from the call (wants to see the doctor, would like home care advice).

To ascertain all this information the triagist must have both clinical knowledge and communication skills. Verbal communication skills 
must compensate for the lack of visual cues, otherwise important information will be missed (51-52). Clinical knowledge includes not only knowledge regarding appropriate questions to ask but also understanding the meaning of the answers. For example: a father telephones to say that his 5 year old son has vomited three times in the last 6 hours. The triagist must know whether this is likely to be significant or not (53-54).

The second phase of telephone triage

In the second phase the triagist assesses the likely clinical significance of information regarding the medical problem and the current personal situation of the patient to determine the degree of urgency and the type of care required. The outcome is based on clinical knowledge and experience, as well as personal intuition (55). The urgency recommendation may vary from immediate (i.e. to be assessed within 1 hour) to lesser degrees of urgency. The type of care recommended may be a face-to-face contact (home visit or at the out-of-hours centre) or advice by telephone regarding home management. If the triagist gives home care advice, the caller must also know when to call back. This advice is called safety net advice.

\section{The third phase of telephone triage}

Following the consultation the triagist writes a report to record what has been discussed with the caller (56). The report is available for different purposes and users. Firstly it is important for the continuity of care. The report is the only documented and therefore quickly accessible source of information about the content of these calls. Secondly, in the Netherlands the report can be sent to the patients' general practitioner to let him know that one of his patients contacted the out-of-hours centre and to inform him on the care advice given. Thirdly, the report can be requested by the patient as part of a complaint procedure. Consequently, the report is central to the continuity of medical care and for medicolegal queries regarding the care provided (57-59). Finally reports can be used for epidemiological research but the reliability of the symptom or diagnostic orientated codes is limited as little information is available on the quality of the coding process (60-61).

\section{Quality of telephone triage}

The quality of medical care is often assessed using audit methods to compare standards for care as recommended by the medical profession (optimum care), to the care actually delivered (actual 
care). To what extent does the care delivered correspond to the recommended standard?

To determine the quality of medical care provided on the telephone the following different aspects can be assessed: the structure, the care process or the outcome or a combination of these aspects (62).

The structure of care provided by telephone at an out-of-hours centre can be assessed by looking at various aspects such as the availability of decision support tools (guidelines, protocols) (12), the time taken for calls to be answered (63) or the time taken to complete home visits (64). Assessment of the quality of care can focus on the assessment of the outcome of telephone triage (65-71) or how the care is delivered, that is on the process of care.

To assess the quality of clinical case handling an assessment of the consultation procedure as well as the outcome needs to be studied. If outcome alone is assessed, the possibility of achieving the appropriate outcome by chance will not be taken into account. On the other hand the consultation procedure could have been followed competently but the outcome of the triage is not appropriate.

The assessment of the quality of the report needs to focus on what appears in the written report compared to the content of the actual conversation between caller and triagist.

\section{Research on telephone triage}

Telephone triage and telephone advice services present new opportunities for medical services to advise on health care matters. Research has been done to investigate different aspects of telephone triage such as: should telephone triage be carried out by doctors or nurses $(5,72)$; investigation of safety aspects $(60,73-77)$; patient compliance with advice given (78-82); the need for protocols (83$87)$; the need for specific communication skills (88-91), and patient satisfaction $(2,65,92-98)$.

In 2006 the Dutch Health Care Inspectorate concluded that the organisation of out-of-hours services had improved considerably since their start but questioned the safety of telephone triage $(12,99)$.

The objective of the study presented in this thesis is to investigate to what extent the process of telephone care at out-of-hours centres in the Netherlands is executed in accordance with accepted professional standards. Accepted professional standards incorporate criteria for communication skills, for clinical management and the quality of the report of the call.

Accordingly, the central research question is: how do triagists at 
Dutch out-of-hours centres perform in terms of quality of the process of care as measured against current accepted standards?

This research focuses on the quality of care given at different outof-hours centres throughout the Netherlands. In order to assess the quality of care the quality of each of the three phases of the process of telephone triage is assessed.

Research on the quality of communication of general practitioners in face-to-face contacts suggests that the duration of a consultation correlates with the quality of communication (100). Whether such a correlation exists for telephone consultations at out-of-hours centres is unknown. In this context a second research question was: to what extent does the duration of the call correlate with the quality of communication?

\section{Relevance of the research project}

Everyone involved in telephone triage has an interest in the safety and quality of the service provided. High quality care is important for the patient, the triagist, the general practitioner, the organisation of the out-of-hours centre, the health insurance company that funds the contacts made by patients and the third-party insurance company covering medicolegal risks.

The results of this research may help to identify whether there are problems within a specific phase of the telephone triage process. Once these are identified, measures to optimise the care by telephone could be implemented.

\section{Outline of this thesis}

The research project was carried out by using Telephone Incognito Standardised Patients (TISPs) who called 17 out-of-hours $(\mathrm{OOH})$ centres in the Netherlands for seven different medical problems. Each $\mathrm{OOH}$ centre was called three times for these seven cases. Thus the quality of clinical case handling and communication was assessed for a total of 357 calls. The $\mathrm{OOH}$ centres were asked for a copy of the call reports as part of the procedure of quality assessment of the content.

Chapter 2 deals with the feasibility and validity of using TISPs, their training, the accuracy of role playing and the rate of detection. The experiences of being a TISP and the difficulties encountered with self-recording were explored.

In chapter 3 the development and reliability of the RICE-communication rating list is presented. This is an instrument to assess the quality of communication skills of triagists. The characters of RICE 
stand for: Reason for calling, Information gathered, $\underline{\text { Care advice }}$ given, Evaluation of the advice.

Chapter 4 describes the criteria and composition of the presented cases, the development and validation of standards for the clinical content of these cases, the validation of the scenario's to be played by the TISPs and the selection of the $\mathrm{OOH}$ centres to be called. The results of the assessments of the clinical case handling and the care advice are presented.

Chapter 5 presents the results of the assessments of the quality of communication of all calls, assessed with the RICE-communication list. The duration of each telephone consultation was determined and correlated with the quality of communication.

In chapter 6 the development of the RICE-report rating instrument is described, an instrument to assess the quality of the reports. All $\mathrm{OOH}$ centres being called were asked for a copy of the reports of the telephone consultations. The results of the assessments of these reports and to what extent the reports reflected what has been discussed with the TISPs are presented.

Chapter 7 examines the whole experience and lessons that can be learned for the future. What has been found, what can be enacted to improve performance, what needs to be investigated? A summary of the main findings, methodological considerations and general conclusions for this study are described. Reflections on the demands of modern communication, safety in health care and support for telephone triage are followed by recommendations and suggestions for further research to improve the quality of telephone triage at outof-hours centres in the Netherlands. 


\section{References}

1. Grol R, Giesen P, van Uden C. After-hours care in the United kingdom, Denmark, and the Netherlands: new models. Health Aff (Millwood). 2006 Nov-Dec;25(6):1733-7.

2. Crouch R. An investigation into the effects of a computer based decision support program on Accident and Emergency nurses' assessment strategies in telephone consultation. 2000. Thesis. University of Surrey.

3. Moriarty $\mathrm{H}$, McLeod D, Dowell A. Mystery shopping in health service evaluation. Br J Gen Pract 2003 Dec;53(497):942-6.

4. Isaacman D, Verdile VP, Kohen FP, Verdile LA. Paediatric telephone advice in the emergency department: results of a mock scenario. Paediatrics 1992; 89: 35-39.

5. Yanovski SZ, Yanovski JA, Malley JD, Brown RL, Balaban DJ. Telephone triage by primary care physicians. Pediatrics 1992 Apr;89(4 Pt 2):701-6.

6. Kempe A, Luberti A, Belman S, Hertz A, Sherman H, Amin D, Dempsey $C$, Chandramouli $U$, MacKenzie T. Outcomes associated with pediatric after-hours care by call centers: a multicenter study. Ambul Pediatr 2003 Jul-Aug;3(4):211-7.

7. Aitken $M$. Telephone advice about an infant given by after-hours clinics and emergency departments. NZ Med J 1995; 108:315-317.

8. Hildebrandt DE, Westfall JM, Smith PC. After-hours telephone triage affects patient safety. J Fam Pract 2003 Mar;52(3):222-7.

9. Carbajal R, Barthez P, Blanc P, Paupe A, Lenclen R, Olivier-Martin M, Simon N. Telephonic advice by an emergency department given in a simulated pediatric case. Arch Pediatr 1996 Oct;3(10):964-8.

10. O'Brien RP, Miller TL. Urgent care center pediatric telephone advice. Am J. Emerg Med 1990 Nov;8(6):496-7.

11. Giesen PHJ, Halink D. Smeerolie van de huisartsenpost. Medisch Contact 2007 maart;9: 371-3.

12. Dutch Health Care Inspectorate. Out-of-hours centres in the Netherlands show teething problems. The Hague, 2004.

13. Bouwel P. Triage op de spoedeisende hulp. LEMMA BV: Utrecht 2002.

14. Massaer B. Geschiedenis van cardiopulmonaire resuscitatie. Gent 2001.

15. Brewer LA $3^{\text {rd }}$. Baron Dominique Jean Larrey (1766-1842). Father of modern military surgery, innovator, humanist. J Thorac Cardiovasc Surg 1986 Dec;92 (6):1096-8.

16. Kennedy K. Triage: techniques and applications in decision making. Ann Emerg Med 1996 Aug;28(2):136-44.

17. Vayre P. Épopée de Dominique Larrey (1766-1842). Chirurgien combattant -Baron du 1er Empire. Ann Chir 2004 Dec;129(10):628-34. 
18. Blagg CR.Triage: Napoleon to the present day. J Nephrol 2004 jul-aug;17(4):629-32.

19. Le Minor JM. Augustin Belloste (1654-1730), aspects of the surgery in military hospital during the Piemont-Savoie War (1686-96). Hst Sci Med 2001 Jul-Sep;35(3):317-27.

20. Houdelette P. Triage of the injured in military surgery and in exceptional situations. J Chir (Paris) 1996;133:363-71.

21. Evenblij M. Gezondheidszorg als slagveld. Medisch Contact Nr. 12 - 19 maart 2004.

22. Aronson SH. The Lancet on the telephone 1876-1975. Med Hist 1977 January; 21(1): 69-87.

23. Edwards B. Seeing is believing; picture building: a key component of telephone triage. J Clin Nurs 1998 Jan;7(1):51-7.

24. Leprohon J, Patel VL. Decision-making strategies for telephone triage in emergency medical services. Med Decis Making 1995 Jul-Sep;15(3):240-53.

25. Hsieh CH, Tsai HH, Yin JW, Chen CY, Yang JC, Jeng SF. Teleconsultation with the mobile camera-phone in digital soft-tissue injury: a feasibility study. Plast Reconstr Surg 2004 Dec;114(7):1776-82.

26. Chen LS, Tsai CY, Liu TY, Tung TH, Chiu YH, Chan CC, Liou DM, Chen $\mathrm{TH}$. Feasibility of tele-ophthalmology for screening for eye disease in remote communities. J Telemed Telecare 2004;10(6):337-41.

27. Crump WJ, Levy BJ, Billica RD. A field trial of the NASA Telemedicine Instrument Pack in a family practice. Aviat Space Environ Med 1996 Nov;67(11):1080-5.

28. Eedy DJ, Wootton R. Teledermatology: a review. Br J Dermatol 2001 Apr;144(4):696-707.

29. Taleb AC, Bohm GM, Avila M, Wen CL. The efficacy of telemedicine for ophthalmology triage by a general practitioner. J Telemed Telecare 2005;11 Suppl 1:83-5.

30. de Mul M, de Bont AA, Reus NJ, Lemij HG, Berg M. Improving the quality of eye care with tele-ophthalmology: shared-care glaucoma screening. J Telemed Telecare 2004;10(6):331-6.

31. Hanson RM, Exley BJ, Ngo P, Fitzpatrick MP, Petering EL, Matthews SJ, Lechner D. Paediatric telephone triage and advice: the demand continues. Med J Aust 2004 Apr 5;180(7):333-5.

32. Pert JC, Furth TW, Katz HP. A 10-year experience in pediatric afterhours telecommunications. Curr Opin Pediatr 1996 Apr;8(2):181-7.

33. Wachter CE. Triage of medical or social issues through preoperative and postoperative telephone calls by primary nurses. Insight 1995 jun;20(2):16-20.

34. Turner D. Can telephone follow-up improve post-discharge outcomes? Br J Nurs 1996 Dec 12-1997 Jan 8;5(22):1361-5. 
35. H.M. Vrehen, E. Drège, E. Schipper, J.T.A. Knape. Telefonische nazorg na dagbehandeling. Medisch Contact 55 nr. 9 - 3 maart 2000.

36. Moran D, Elliott R, McKinley S. The Royal North Shore Hospital Australia. ICU nurse initiated telephone follow up service. Intensive Crit Care Nurs 2005 Feb;21(1):47-50.

37. Smith CW, Burcham L, Chase JA, Bashore PA. Telephone triage of upper extremity problems. Orthop Nurs 1995 Nov-Dec;14(6):31-6.

38. Allen D. Telephone follow up for older people discharged from A\&E. Nurs Stand 1997 Aug 6;11(46):34-7.

39. Marsden J. An evaluation of the safety and effectiveness of telephone triage as a method of patient prioritization in an ophthalmic accident and emergency service. J Adv Nurs 2000 Feb;31(2):401-9.

40. Philipp BL. Every call is an opportunity. Supporting breastfeeding mothers over the telephone. Pediatr Clin North Am 2001 Apr;48(2): 525-32.

41. Tacetti G. Telephone consultations in chronic diseases: an experience in cystic fibrosis. BMJ 5 June 2002.

42. R A Hughes, M E Carr, A Huggett and C E A Thwaites. Review of the function of a telephone helpline in the treatment of outpatients with rheumatoid arthritis. Ann Rheum Dis 2002;61;341-345.

43. UK HIV Helpline 2006.

44. National HIVIAIDS Clinician's Consultation center 2006. California USA.

45. Preston FA. Telephone triage.Clin J Oncol Nurs 2000 Nov-Dec; 4(6):294-6.

46. Scalvini S, Capomolla S, Zanelli E, Benigno M, Domenighini D, Paletta L, Glisenti F, Giordano A. Effect of home-based telecardiology on chronic heart failure: costs and outcomes. J Telemed Telecare 2005;11 Suppl 1:16-8.

47. Spelten E. De Huisartsenlijn in de praktijk. Prismant/Achmea. Utrecht 2002.

48. Call center houdt artsen uit de wind. Automatisering Gids 06-04-01.

49. Nederland kan uit met enkele "teledokters". ZN journaal $2001 \mathrm{nr} .15$.

50. Dankzij ICT naar de juiste hulp en informatie. HMF 4-december 2001.

51. Levy JC, Rosekrans J, Lamb GA, Friedman M, Kaplan D, Strasser P. Developmentand field testing of protocols for the management of pediatric telephone calls: protocols for pediatric telephone calls. Pediatrics 1979 Nov;64(5):558-63.

52. Pettinari CJ, Jessopp L. "Your ears become your eyes": managing the absence of visibility in NHS Direct. J Adv Nurs 2001 Dec;36(5): 668-75.

53. Yanovski SZ, Yanovski JA, Malley JD, Brown RL, Balaban DJ. Telephone triage by primary care physicians. Pediatrics 1992 Apr;89 (4 Pt 2):701-6. 
54. Aitken M. Telephone advice about an infant given by after-hours clinics and emergency departments. NZ Med J 1995; 108:315-317.

55. Arslanian-Engoren C. Gender and age bias in triage decisions. J Emerg Nurs 2000 Apr;26(2):117-24.

56. Fatovich DM, Jacobs IG, McCance JP, Sidney KL, White RJ. Emergency department telephone advice. Med J Aust 1998; 169:143-146.

57. Röhlig HW. Documentation in law and general practice. Zentralbl Chir 1999;124 suppl 1:49-51.

58. Roberts RG. Seven Reasons Family Doctors Get Sued and How to Reduce Your Risk . Fam Pract Manag 2003 Mar;10(3):29-34.

59. Car J, Freeman G, Partridge M, Sheikh A. Improving quality and safety of telephone based delivery of care: teaching telephone consultation skills. Qual Saf Health Care 2004 Feb;13(1):2-3. Editorial.

60. Giesen P. Quality of out-of-hours care in the Netherlands. Thesis. UMC St Radboud Nijmegen 2007.

61. Spies TH, Mokkink HG, De Vries Robbé PF, Grol RP. Which data source in clinical performance assessment? A pilot study comparing self-recording with patient records and observation. Int J Qual Health Care 2004 Feb;16(1):65-72.

62. Leenen HJJ. Handboek Gezondheidsrecht, Gezondheidszorg en Recht. Samson H.D. Tjeenk Willink. Alphen aan den Rijn 1991.

63. Inspectie voor de Gezondheidszorg. Telefonische bereikbaarheid huisartsenposten. 2005.

64. Giesen P. Wachten op visite. Medisch Contact 12 november 2004; 59 $\mathrm{nr} 46$.

65. Post J. Large scale primary care service during after-hours (Grootschalige huisartsenzorg buiten kantooruren). Thesis, University of Groningen, The Netherlands, Groningen 2004.

66. Fatovich DM, Jacobs IG, McCance JP, Sidney KL, White RJ. Emergency department telephone advice. Med J Aust 1998; 169:143-146.

67. Belman S, Chandramouli V, Schmitt BD, Poole SR, Hegarty T, Kempe A. An assessment of pediatric after-hours telephone care: a 1-year experience. Arch Pediatr Adolesc Med 2005 Feb;159(2):145-9.

68. Light PA, Hupcey JE, Clark MB. Nursing telephone triage and its influence on parents' choice of care for febrile children. J Pediatr Nurs 2005 Dec;20(6):424-9.

69. Crouch R, Patel A, Williams S, Dale J. An analysis of telephone calls to an inner-city accident and emergency department. J R Soc Med 1996 Jun;89(6):324-8.

70. Wahlberg AC, Wredling R. Telephone nursing: calls and caller satisfaction. Int J Nurs Pract 1999 Sep;5(3):164-70.

71. Salisbury C, Trivella M, Bruster S. Demand for and supply of out of hours care from general practitioners in England and Scotland: observational study based on routinely collected data. BMJ 2000 March 320(7235):618-21. 
72. Perrin EC, Goodman HC. Telephone management of acute pediatric illnesses. New Eng J Med 1978(3):130-5.

73. Foster J, Jessopp L, Dale J. Concerns and confidence of general practitioners in providing telephone consultations. Br J Gen Pract 1999 Feb;49(439):111-3.

74. Dale J, Williams S, Foster T, Higgins J, Snooks H, Crouch R, HartleySharpe C, Glucksman E, George S. Safety of telephone consultation for "non-serious" emergency ambulance service patients. Qual Saf Health Care 2004 Oct;13(5):363-73.

75. Killip S, Ireson CL, Love MM, Fleming ST, Katirai W, Sandford K. Patient safety in after-hours telephone medicine. Fam Med 2007 Jun;39(6):404-9.

76. Bunn F, Byrne G, Kendall S. Telephone consultation and triage: effects on health care use and patient satisfaction. Cochrane Database Syst Rev 2004 Oct 18;(4):CD004180.

77. Tijssen R. De "NHG-Telefoonwijzer": een goede leidraad voor triage? 2004 Nijmegen. Faculty of Medicine. UMC 045125.

78. Turner V. Telephone triage in western Australia. The medical journal of Australia 2002;176:100-103.

79. van Uden CJT. Studies on general practice out-of-hours care. Maastricht 2004. Thesis.

80. Wahlberg AC. Telephone advice nursing. Department of nursing Karolinska Institutet, Stockholm, Sweden. 2004. Thesis.

81. Fatovich DM, Jacobs IG, McCance JP, Sidney KL, White RJ. Emergency department telephone advice. Med J Aust 1998; 169:143-146.

82. Moore JD, Saywell RM, Thakker N, Jones TA. An analysis of patient compliance with nurse recommendations from an after-hours call center. Am J Manag Care 2002 Apr;8(4):343-51.

83. Belman S, Murphy J, Steiner JF, Kempe A. Consistency of triage decisions by call center nurses. Ambul Pediatr 2002 Sep-Oct;2(5):396400.

84. Rutenberg C. What do we really KNOW about telephone triage? J Emerg Nurs 2000;26:76-8.

85. Wachter D. Pediatric Telephone Triage Protocols: Standardized Decisionmaking or a False Sense of Security? Annals of Emergency Medicine 1999;33(4):388-94.

86. B. Chevallier, M. Sznajder, R. Assathiany et le groupe de pédiatrie générale de la Société française de pédiatrie. La pédiatrie par téléphone : un exercice difficile. Archives de Pédiatrie Volume 11, Issue 9, Septembre 2004, Pages 1033-1035.

87. Car J, Sheikh A. Telephone consultations. BMJ 2003;326:966-969 (3 May). 
88. Derkx HP, Rethans J-J E, Knottnerus JA, Ram P. Assessing communication skills of clinical call handlers working at an out of hours centre. The development of the RICE rating scale. Br J Gen Pract 2007 May;57 (538):383-7.

89. Moscato SR, Valanis B, Gullion CM, Tanner C, Shapiro SE, Izumi S. Predictors of patient satisfaction with telephone nursing services. Clin Nurs Res 2007 May;16(2):119-37.

90. Moscato SR, David M, Valanis B, Gullion CM, Tanner C, Shapiro S, Izumi S, Mayo A. Tool development for measuring caller satisfaction and outcome with telephone advice nursing. Clin Nurs Res 2003 Aug;12(3):266-81.

91. Kosower E.,Inkelis S,Seidel J. Telephone T.A.L.K.: a teaching/ assessment tool for medical training. J Biocommun. 1996;23(1):22-6.

92. CJT van Uden, AJHA Ament, SO Hobma, PJ Zwietering,and HFJM Crebolder. Patient satisfaction with out-of-hours primary care in the Netherlands. BMC Health Serv Res 2005 Jan 15;5(1):6.

93. Christensen MB, Olesen F. Out of hours service in Denmark: evaluation five years after reform. BMJ 1998 May 16;316(7143):1502-5.

94. St George IM, Cullen MJ. The Healthline pilot: call center triage in New Zealand. N Z Med J 2001 Sep 28;114(1140):429-30.

95. Shah CP, Egan TJ, Bain HW. An expanded emergency service: role of telephone services in the emergency department. Ann Emerg Med $1980 \mathrm{Dec} ; 9(12): 617-23$.

96. Patel A, Dale J, Crouch R. Satisfaction with telephone advice from an accident and emergency department: identifying areas for service improvement. Qual Health Care 1997 Sep;6(3):140-5.

97. McKinley R, Stevenson K, Adams S, Manku-Scott T. Meeting patient expectations of care: the major determinant of satisfaction with out-ofhours primary medical care? Fam Pract 2002; 19:333-8.

98. Moll van Charante E, Giesen P, Mokkink H, Oort F, Grol R, Klazinga N, Bindels P. Patient satisfaction with large-scale out-of-hours primary health care in The Netherlands: development of a postal questionnaire. Fam Pract. 2006 Aug;23(4):437-43. Epub 2006 Apr 26.

99. Dutch Health Care Inspectorate. Quality of out-of-hours centres improved since 2003 (Kwaliteit huisartsenposten verbeterd sinds 2003). The Hague. December 2006.

100. Ram P, Grol R , Rethans JJ, Van der Vleuten C. Assessment of communicative and medical performance of general practitioners in daily practice. Validity, reliability and feasibility of video observation. Med Educ 1999;33:447-454. 


\title{
Chapter 2
}

\section{New methodology for using incognito standardised patients for telephone consultation in primary care}

\author{
H.Derkx ${ }^{1}$ \\ JJ. Rethans ${ }^{2}$ \\ B.Maiburg ${ }^{1}$ \\ R.Winkens ${ }^{1}$ \\ J.A.Knottnerus ${ }^{1}$
}




\section{Abstract}

\section{Background}

Many countries are now using call centres as an integral part of out-of-hours primary care. While there has been research on safety issues within telephone consultations, there has been no published research on how to train and/or use standardised patients calling for medical advice and on the accuracy of role-playing.

\section{Objectives}

To assess the feasibility and validity of using Telephone Incognito Standardised Patients (TISPs), the accuracy of role plays and the rate of detection. To explore the experiences of being a TISP and the difficulties encountered with self-recording the calls.

\section{Methods}

Twelve TISPs were trained in role-play by presenting their problem to a general practitioner and a nurse and to self-record calls. Calls were made to 17 different out-of-hours centres from home. Of the four or five calls per evening, one call was assessed for accuracy of role play. Retrospectively the out-of-hours centres were asked whether they had detected any calls made by a TISP. The TISPS filled in a questionnaire concerning their training, the self-recording technique and personal experiences.

\section{Results}

The TISPs made 375 calls during 84 evenings. The accuracy of the role-play was close to $100 \%$. A TISP was called back the same evening for additional information in 11 cases. Self-recording caused extra tension for some TISPs. All fictitious calls remained undetected.

\section{Conclusion}

Using the method described TISPs can be valuable both for training and assessment of performance in telephone consultation carried out by doctors, trainees and other personnel involved in medical services. 
What is already known on this subject

Several studies have examined the use of Incognito Standardised Patients (ISPs) in a face-to-face consultation.

\section{What this study adds}

This study adds information on the methodology of using telephone ISPs within the primary care setting of an out-of-hours centre and to self-record these calls. It presents the methods' validation, feasibility, training method, preparation and criteria used to assess the accuracy of role-playing by Telephone ISPs. 


\section{Introduction}

Standardised patients are lay persons taught to portray patients in a standardised and consistent fashion (1). They have been used as "unannounced" or "Incognito" Standardised Patients (ISPs) for many years to assess the performance of students and health care professionals during face-to-face consultations. Performance assessment is defined as measuring what the observed person does in actual professional practice without being aware of being assessed. There is evidence that the ISP-methodology is a powerful instrument to assess clinical performance (2-4).

In many countries doctors or nurses handle telephone requests for medical advice at call centres during the out-of-hours period (5-11). Several studies describe the use of Telephone Incognito Standardised Patients (TISPs) to assess safety issues in this context (12-19) but without assessing the accuracy of their role-playing.

There are several differences between use of ISPs for face-to-face and telephone consultations. A TISP cannot see the call handler and therefore all communication is strictly vocal without the usual multitude of visual cues. Also a TISP does not need to fill in a checklist after the consultation as the call can be recorded and the items to be assessed can be studied later. Therefore a good quality audible recording of the telephone consultation is required to make proper assessments later (20). The TISP can read the roledocumentation with all the required information in front of him/her but their voice should sound natural. Another difference is that a TISP can make a call from any geographic location, whilst pretending to be in the neighbourhood of the medical service that has been contacted. Also different roles can be played by the same TISP.

An important issue with every ISP is the accuracy of role-playing. Accuracy can be defined as the proportion of clinical features presented correctly during the consultation (21). Another important issue is whether call handlers will reveal that a call has been made by an TISP rather than a real patient ('detection rate').

In the literature we found no information on the validity, feasibility and preparation of TISPs, the accuracy of their role-play, their detection rate and how their calls were recorded for further assessment.

We designed a study to address the following research questions:

1. To what extent is it feasible to use TISPs within the primary care setting of an out-of-hours centre, with emphasis on the preparation required? The study included the feasibility of self-recording at home by the TISPs, the accuracy of their role-play and their detection rate.

2. What experiences have TISPs using this new methodology? 


\section{Methods}

\section{Selection of clinical cases}

The research team developed seven clinical roles for the TISPs, validated by a group of 12 general practitioners (GPs) selected at random from different Dutch areas. The seven roles were presented regularly by telephone to out-of-hours centres; role 1: a child of 5 years with fever, roles 2 and 3: adult with fever, roles 4 and 5: child of 5 years with vomiting and roles 6 and 7 : adult with epistaxis (22-24). Roles 2 and 3, 4 and 5, 6 and 7 consisted of small variations within similar scenarios. For each case all GPs agreed that the required disposition could either be a self-care advice or a consultation at the out-of-hours centre on the same evening. None of the cases would require immediate care or a home visit.

\section{Selection and training of the TISPS}

The University of Maastricht has used face-to-face ISPs for many years for medical student training. From this pool a group of ISPS was selected, based on experience and the clarity of speech. Three scenarios were to be played by a mother calling about her five year old child, the other four were to be played by male or female adults. To lessen the chance that a call handler would recognise the voice of a TISP every scenario was to be presented by two different TISPs, each of whom would call the same out-of-hours centre after a time interval of six weeks.

The two TISPs with the same role were simultaneously trained in two 1.5 hour sessions by two nurses and a general practitioner (GP), all with previous experience of working at a medical call centre. The TISPs were instructed and trained to provide further information only on request. To speak naturally during the consultation extra attention was given to the use of their voice with regard to the expression of non-verbal signals such as surprise, disappointment or anxiety. The training also included attention to the prescribed opening and closing sentences and how to react to a request to come to the outof-hours centre the same evening, which was obviously impossible. In case of a return call, made to the mobile phone of the TISP, they were trained to make notes of what was discussed directly after that call.

Midway through the project all TISPs returned to the research centre to have a refresher training lasting one hour. No changes were made in the existing information or their role. 


\section{Description of scenarios}

For each case a scenario was developed with three kinds of information: general, case specific and local information.

The general information described all personal patient data: family name, date of birth, home address and the mobile phone number of the TISP.

The case specific information described the opening and closing sentence, the reason for calling (e.g. medication or consultation), the personal background of the caller (e.g. caller is worried) and the answers to questions of the call handler about medical issues.

The local information contained information about the out-of-hours centres (address, telephone number), an area map and a self-made picture of the fictitious residence of the TISP, so the TISP had an idea about the area of the out-of-hours centre (25). All locations were visited by the research coordinator before the training started to be sure that they were appropriate and to enable to pass on relevant local information to the TISPs during training.

\section{Selection of call centres and calls}

Previous research showed that a sufficient time lapse between the announcement of a standardised patient visit and the actual visit can prevent detection (5). Therefore one year before making the actual calls all 105 out-of-hours centres in the Netherlands were asked for permission to be called by the TISPs and to record the calls (1). From the 98 that gave permission 17 centres were selected at random. The call handlers at these out-of-hours centres did neither know that they were selected, nor when they would be called or the names that would be used by the TISPs.

Each case was to be presented three times to each of the 17 out-ofhours centre, so 357 calls were scheduled.

\section{Recording of calls}

As the TISPs lived in a radius of 20-30 kilometres from the research institute we decided to allow them to make the calls from their own homes. We found a system that met standards for adequately self recording the calls. (Detailed information on the equipment used on request).

\section{Pilot telephone calls}

To be sure that the TISPs had all the required information about the out-of-hours centres and that they were ready to play their role, two pilot studies were performed.

Pilot one was to ensure that the TISPs had all the required and correct general, local and specific information about the case to be 
presented. To check all this the trainers themselves called every selected out-of-hours centre for medical advice using fictitious personal data.

Pilot two was to check the accuracy of the role-play and the selfrecording of calls by the TISPs. Therefore they called a medical call centre that had been forewarned, taking on their assigned role with fictitious personal data and self-recorded the call. The call handlers at the medical call centre were aware that they were being called by a TISP as the fictitious name was flagged as a TISP in their system. They were instructed to handle this trial call as they normally would do and were asked to enter in the report their general impression of the performance of the TISP. These trial calls were also assessed by the researcher and the trainers.

\section{Assessment of accuracy}

During the research project the TISPs called four to five different out-of-hours centres per evening. The TISPs were free to choose in which order they wanted to call the out-of-hours centres on a particular evening. The third call was selected to measure accuracy of role-playing.

Each assessment of the TISP was made by two assessors who worked as experienced triagists at a medical call centre. They used the following four criteria developed by the research team:

- was the opening of the conversation according to the instructions?

- did the TISP give the correct answers to questions asked by the call handler?

- did the TISP give extra information only if asked for?

- was the closing of the conversation according to the instructions?

The assessors received a copy of the recorded call on a CD and the information the TISPs received about the role to play. They could respond to each of the criteria with YES, NO or UNSURE. The TISPs were informed that their role-play would be assessed without informing them which call would be selected for assessment.

Detection of standardised patients by the out-of-hours centre After all calls were made we sent a questionnaire to the 98 out-ofhours centres that had given permission to be called. 
They were asked to answer questions about:

- indication of being called by a standardised patient. If so:

- at what date and for what reason;

- was the call discovered during or after the call and how sure is the call handler about being called by a standardised patient $(0-100 \%)$;

- did the discovery influence the call handling?

Evaluation by the TISPS

The TISPs were asked to fill in a questionnaire about their experiences both on a quantitative and qualitative way. Questions addressed issues such as training and preparation and the self recording, personal impressions and experiences were also asked for. Furthermore the TISPs were interviewed by the researcher and the trainer to talk about their personal experiences.

\section{Results}

\section{Selection and training of the TISPS}

Of the 14 selected and trained TISPs two dropped out for personal reasons very shortly before the research project started. Their task was taken over by the TISP who was already trained for the same role, so the performance of 12 TISPs could be assessed.

\section{Recording the call}

We scheduled 357 calls but the TISPs had to make 375 calls as 18 calls were not recorded correctly due to technical problems during the recording. The TISP concerned received a new set of fictitious personal data to make an extra call a few weeks later.

It took the TISPs 1.5-2 hours per evening to make 4-5 calls. All calls were made between March 2006 and March 2007. On 11 occasions a TISP received the same evening a return call from the GP on call at the out-of-hours centre and three times from the administration of a centre after 2-3 weeks to answer some additional questions. Of these 14 return calls 11 were answered by the TISP and notes were made of that conversation. Three calls were not answered for different reasons.

The calls were assessed by 12 different assessors and they all agreed on the excellent quality of the recording.

\section{Pilot telephone calls}

From the first pilot we learned that some centres ask for the zip code of the residence. This information was added to the local information. The second pilot showed that the TISPs played their role in a convincing way. Some of the TISPs received advice about 
refining their presentation of the opening sentence as they tended to read out this sentence instead of formulating it in a personal style.

\section{Assessment of accuracy}

Using the procedures described a total of 84 calls were available for assessing accuracy of role play. The results for the four criteria as assessed by two assessors are displayed in Table 1. The assessors agreed upon the outcome of their assessments for nearly $100 \%$.

\section{Detection}

The 17 out-of-hours centres that had been called stated that they had not detected any call from a TISP. Two out-of-hours centres that were not called by one of our TISPs, stated that they did receive a call from a TISP.

\section{Experiences of the TISPS}

Training and preparation: although not every encountered situation was covered in the training the TISPs were able to handle difficult situations because they had rehearsed their role in every detail. The TISPs stated that the training which involved presenting their case to a GP and a nurse was very helpful, especially as the return calls on the same evening were made by a GP. The try-out call to the medical call centre gave them self-confidence. They felt that the extra attention for playing the role using merely verbal communication helped them to play the role more naturally.

Information: none of the TISPs met a question they were not prepared for. Some TISPs were aware of the fact that they had not finished the conversation with the correct closing sentence, mainly because some call handlers finished the consultation in a way that took the TISP by surprise. The presence of (self made) pictures of the fictitious residence together with an area map had helped the TISPs to enter into their role.

Calling and self-recording: the TISPs appreciated that they could call from home. Sometimes the self-recording had caused more tension then the call itself. Both role-playing and recording to a high standard required intensive concentration with no distractions. Making five calls per evening was considered to be the maximum.

Personal experiences: the most frequent comments were "I missed the eye contact with the care adviser" and "I was glad that I was trained to play my role using merely my voice".

Other comments were: "You have to stay alert for a return call not only for the rest of the evening, but even for many days later to act immediately and identically as in your role". 


\section{Discussion}

To our knowledge this study is the first research on the feasibility of using TISPs in a health care setting and the assessment of the accuracy of their role-playing. Therefore, many of the procedures described are the result of a very careful step by step approach to the introduction of TISPs.

Although some members of the research team have expertise in training standardised patients for use in Incognito Standardised Patients (ISP) studies pertaining to actual visits with face-to-face contacts, we could not merely rely on this experience to train and prepare TISPs optimally to call out-of-hours centres for medical advice. From this perspective we believe our results are innovative. For example, we provided the TISPs with self-made pictures of all the residences they were believed to stay. The study confirmed our expectation that this extra information could help the TISPs to play their role. In a new study we would collect this kind of information in other ways (e.g. from websites) which is less time consuming (26). Nevertheless this information needs to be accurate and up to date to prevent detection.

Although TISPs, recording calls themselves, do not need training to fill in checklists after the consultation, they face other challenges. Their experiences showed that thorough training for role-play is needed to be prepared for handling the many different situations which they might encounter. Most unexpected were the calls from some out-of-hours centres 2 or 3 weeks later during the day when the administration of a centre requested where to send the bill for the telephone consultation. This situation was very troublesome for the TISPs as they were suddenly confronted with questions regarding personal data relating to the fictitious person they had played.

Although the return calls were not recorded we believe that no information regarding the consultation was lost as the TISPs were trained to make notes of the conversation directly after the call. TISPs should be instructed to answer all telephone calls following their role play, so that no return call from an out-of-hours centre remains unanswered.

Role playing and recording the calls at the same time caused extra tension for some of the TISPs but the possibility of recording the calls at home rather than having to travel somewhere else in the evening was preferred by all the participants. There is a slight risk of failure of self-recording the call but the advantage of consulting by telephone is that a new call can easily be made by the same TISP after adjusting the personal data.

As we had no experience with using TISPs we decided to present only cases that did not require a home visit or an emergency 
consultation as detection is more likely to occur in those situations. Further research on using TISPs for all types of clinical cases, including emergency cases, will be our next challenge.

We were pleased to see that the TISPs played their role with great accuracy. As not all TISPs performed completely according to the instructions with regard to the opening or closing sentence special attention is required for these aspects during training.

The method of using TISPs is feasible in any country but privacy regulations for recording the calls might cause restrictions in some countries ${ }^{1}$.

We conclude that it is feasible to use standardised patients on the telephone both for training and assessment of performance in telephone consultation carried out by doctors, trainees and other personnel involved in medical services after good preparation and training in role-play. Self-recording of the calls at home to a high standard is also feasible.

\section{Suggestions for further research}

Further research could study the use of telephone ISPs presenting a greater variety of clinical cases, including cases requiring immediate care which were not included in this study.

${ }^{1}$ Ethical approval: Under Dutch law no ethical approval is needed to phone or to record calls made by standardised patients to an out-of-hours centre once permission has been given by the management of the $\mathrm{OOH}$ centre. 
Table 1: Results of assessment of performance of role-playing per item (168 assessments for 84 calls)

(Yes= according to instruction; No= not according to instruction)

\begin{tabular}{|l|c|l|l|l|}
\hline & $\begin{array}{c}\text { Opening } \\
\text { sentence }\end{array}$ & $\begin{array}{c}\text { Correct } \\
\text { answers }\end{array}$ & $\begin{array}{c}\text { Extra } \\
\text { information } \\
\text { on request }\end{array}$ & $\begin{array}{c}\text { Closing } \\
\text { sentence }\end{array}$ \\
\hline Yes & 162 & 166 & 166 & 149 \\
\hline Unsure & 5 & 2 & 2 & 9 \\
\hline No & 1 & 0 & 0 & 10 \\
\hline
\end{tabular}




\section{References}

1. Barrows H.S. An overview of the uses of standardized patients for teaching and evaluating clinical skills. Academic Medicine 1993;68(6): 443-51.

2. Van der Vleuten C, Swanson D. Assessment of clinical skills with standardized patients:state of the art. Teaching and Learning in Medicine 1990;2:58-76.

3. Rethans JJ, Norcini JJ, Baron-Maldonado M, Blackmore D, Jolly BC, LaDuca T, Lew S, Page GG, Southgate LH. The relationship between competence and performance: implications for assessing practice performance. Med Educ 2002 Oct;36(10):901-9.

4. Maiburg $\mathrm{BH}$, Rethans JJ, van Erk IM, Mathus-Vliegen LM, van Ree JW. Fielding incognito standardised patients as 'known' patients in a controlled trial in general practice. Med Educ 2004 Dec;38(12):122935.

5. Crouch R. An investigation into the effects of a computer based decision support program on Accident and Emergency nurses' assessment strategies in telephone consultation. Dissertation. University of Surrey 2000.

6. Lancet. Nurse telephone-triage. Lancet 2001 Feb 3;357(9253):323.

7. Grol R, Giesen P, van Uden C. After-hours care in the United kingdom, Denmark, and the Netherlands: new models. Health Aff (Millwood). 2006 Nov-Dec;25(6):1733-7.

8. CJT van Uden, AJHA Ament, SO Hobma, PJ Zwietering, and HFJM Crebolder. Patient satisfaction with out-of-hours primary care in the Netherlands. BMC Health Serv Res 2005 Jan 15;5(1):6.

9. Wahlberg AC. Telephone advice nursing. Department of nursing Sweden. Dissertation 2004.

10. Meer A. Die ambulante Notfallversorgung in der Schweiz im Umbruch. Primary care 2005;5:nr. 20.

11. Christensen MB, Olesen F. Out of hours service in Denmark: evaluation five years after reform. BMJ 1998 May 16;316(7143):1502-5.

12. Rupp RE, Ramsey KP, Foley JD. Telephone triage: results of adolescent clinic responses to a mock patient with pelvic pain. J Adolesc Health 1994 May;15(3):249-53.

13. O’Brien RP, Miller TL. Urgent care center pediatric telephone advice. Am J Emerg Med 1990 Nov;8(6):496-7.

14. Yanovski SZ, Yanovski JA, Malley JD, Brown RL, Balaban DJ. Telephone triage by primary care physicians. Pediatrics 1992 Apr;89(4 Pt 2):701-6.

15. Aitken $M$. Telephone advice about an infant given by after-hours clinics and emergency departments. NZ Med J 1995; 108:315-317. 
16. Carbajal R, Barthez P, Blanc P, Paupe A, Lenclen R, Olivier-Martin M, Simon N. Telephonic advice by an emergency department given in a simulated pediatric case. Arch Pediatr 1996 Oct;3(10):964-8.

17. Sloane PD, Egelhoff C, Curtis P, McGaghie W, Evens S. Physician decision making over the telephone. J Fam Pract 1985 Oct;21(4): 279-84.

18. Isaacman D, Verdile VP, Kohen FP, Verdile LA. Paediatric telephone advice in the emergency department: results of a mock scenario. Paediatrics 1992; 89: 35-39.

19. Moriarty $H$, McLeod $D$, Dowell $A$. Mystery shopping in health service evaluation. Br J Gen Pract 2003 Dec;53(497):942-6.

20. Van Thiel J, Ram P, van Dalen J. MAAS-Global Manual 2000. Maastricht University, The Netherlands.

21. Rethans JJ, Gorter S, Bokken L, Morrison L. Unannounced standardized patients in real practice: a systematic literature review. Med Educ 2007 June;41(6):537-49.

22. Post J. Large scale primary care service during after-hours (Grootschalige huisartsenzorg buiten kantooruren). Thesis, University of Groningen, The Netherlands, Groningen 2004.

23. Crouch R, Patel A, Williams S, Dale J. An analysis of telephone calls to an inner-city accident and emergency department. R Soc Med 1996 Jun;89(6):324-8.

24. Belman S, Chandramouli V, Schmitt BD, Poole SR, Hegarty T, Kempe A. An assessment of pediatric after-hours telephone care: a 1-year experience. Arch Pediatr Adolesc Med 2005 Feb;159(2):145-9.

25. Rethans JJ, Drop R, Sturmans F, Van der Vleuten C. A method for introducing standardized (simulated) patients into general practice consultations. Br.J.Gen Pract 1991;41:94-96.

26. Beullens J, Rethans JJ, Goedhuiys J, Buntinx F. The use of standardized patients in research in general practice. Family Practice 1997;14: 58-62. 


\section{Chapter 3}

\section{Assessing communication skills of clinical call handlers working at an out-of-hours centre. The development of the RICE rating scale.}

H.Derkx ${ }^{1}$

JJ. Rethans ${ }^{2}$

P.Ram ${ }^{1}$

J.A.Knottnerus ${ }^{1}$

Published in British Journal of General Practice 2007; 57: 383-387. 


\section{Abstract}

\section{Background}

Out-of-hours centres provide telephone support to patients with medical problems. In most of these centres specially trained nurses handle incoming telephone calls. They assess patients' needs, the degree of urgency, and determine the level of care required. Assessment of the medical problem and the quality of 'care by phone' depend on the medical and communication skills of the call handlers.

\section{Aim}

To develop a valid, reliable, and practical rating scale to evaluate the communication skills of call handlers working at an out-of-hours centre and to improve quality of communication.

\section{Design of study}

Qualitative study with focus groups followed by validation of the rating scale and measurement of reliability (internal consistency).

\section{Setting}

Out-of-hours centres in the Netherlands.

\section{Method}

A focus group developed the rating scale. Experts with experience in training and evaluating communication skills of medical students and general practitioners commented on the scale to ensure content validity. The reliability of the rating scale was tested in a pilot in which ten specially trained assessors scored six telephone calls each.

\section{Results}

The scale, known as the RICE rating scale, has 17 items divided over four different phases of the telephone consultation: Reason for calling; Information gathering; Conclusion; and Evaluation (RICE). Content validity of the scale was assessed by two experts. Reliability of the scale tested in the pilot was 0.73 (Cronbach's alpha).

\section{Conclusion}

Establishing a rating scale to assess the communication skills of call handlers which meets common scientific demands, such as content validity and reliability, proved successful. This instrument can be used to give feedback to call handlers. 


\section{Keywords}

after-hours; care; communication; quality assessment; telephone consultation.

\section{"How this fits in"}

Call handlers at out-of-hours centres need excellent skills in telephone communication. An instrument to assess those skills was unavailable. This paper describes the development of an instrument, the RICE rating scale, for assessing the communication skills of call handlers at an out-of-hours centre. 


\section{Introduction}

In many parts of the world out-of-hour medical call centres provide support to patients who call for medical advice (for example, in the US, UK, Denmark, Netherlands, Australia). Call handlers at call centres are usually registered nurses who triage the medical problem. Triage by telephone implies that the call handler assesses the degree of urgency of the patients' needs, and offers advice to the patient about the care that is required.

There is evidence that good communication skills between doctors and patients during face-to face consultations have a positive effect on patient outcome (1-5). Good communication skills during 'care-by-phone' are of high importance (2,6-10). Call handlers are confronted with a mix of undifferentiated clinical needs and they have to establish rapport quickly with usually unknown patients. Good communication skills are needed because of high medicolegal risk associated with providing telephone advice and limited resources at out-of-hours centres. In addition, call handlers can only identify some auditory clues and are unable to pick up on visual cues from callers $(7,11-13)$.

Current instruments for assessing communication skills of primary care providers, nurses, and doctors during surgery hours are unlikely to be applicable to telephone consultations due to the absence of visual cues (14). To become competent, call handlers should be specially trained in communication skills for telephone consultation. Research suggests that assessment of performance in real practice is needed to guarantee quality of care (15-17). To assess the quality of care provided by call handlers, the investigators searched for a suitable instrument. The literature search was conducted using the keywords: 'communication', 'telephone', 'assessment', 'quality', 'scoring', and 'after-hours care' (PubMed, Medline, PsycARTICLES, Cochrane database). No instrument was identified from the literature. Therefore, the aim of the study was to develop a valid, reliable, and practical instrument to assess the communication skills of call handlers working at out-of-hours centres. The study took place in the Netherlands which has over 100 of these centres with more than 2500 active call handlers in operation.

\section{Methods}

\section{Content validity}

To enhance content validity of the proposed instrument, a focus group was formed. The group comprised eight individuals representing the four stakeholder groups involved in telephone calls to an out-of-hours centre: patients, call handlers, doctors, and the management team. Patients were members of patient groups; call 
handlers worked at out-of-hours call centres as supervisors or call handlers; GPs worked at out-of-hours centres and were involved in ensuring quality of care; and members of the management team were involved with general issues of management at out-of-hours centres. Each stakeholder group was represented by two members of each group with experience in communication and/or working at an out-of-hours centre.

Meetings were led by a neutral moderator who followed focus group protocols (18). The focus group met twice over a period of four weeks. During these meetings, lasting three hours each, items for the rating scale were identified.

At the start of the first meeting each member was asked to comment on the following statement: 'A telephone consultation by a call handler needs to follow a recognisable structure' (19). After reaching agreement on this statement, each member was asked to write down such a structure. Individual proposals were collected and presented to the group.

In the group discussion that followed, consensus was reached on the structure of telephone conversations in which four essential phases were identified as essential: Reason for calling; Information gathering; Conclusion; and Evaluation (leading to use of the acronym 'RICE' to denote the four phases). A period of interruption was identified as another important, although not essential, component of telephone communication. During a period of interruption the call handler puts the caller on hold to discuss the problem with a colleague or to study guidelines. During the first meeting members also wrote down what they each considered to be required communication skills of the call handler during the four phases and the period of interruption. Their suggestions were collected, presented, and discussed until a consensus was obtained. Each required skill was expressed as an item. To assess the skill level of call handlers, the group decided to use a five-point Likert scale ranging from 0 (skill is absent) to 4 (good). Finally, the group discussed who should assess the performance of a call handler. Members agreed that this should be handled by a peer colleague call handler. Before the second meeting all members received by mail the rating scale with the 17 items they agreed on during the first meeting. A manual was also supplied which provided descriptions of each item and specified how to rate call handlers using the Likert scale. During the second meeting the group decided which item, each representing a required skill, should be present during more than one phase (for example, making a summary, or listening attentively during most phases). The descriptions of items in the manual were changed or adjusted where needed.

For further content validation the rating scale was presented to two 
communication skills experts. They were given the descriptions of the items and asked whether they agreed with structuring a telephone consultation according to the four phases, and if items could be omitted or added.

\section{Reliability}

To determine the reliability (internal consistency) of the rating scale, a pilot was performed in which 10 raters received special training and assessed six actual telephone calls using the rating scale. One of the raters was a member of the focus group. All raters were nurses experienced in call handling. Before training, raters received the manual and the rating scale to be studied at home. Training was led by a teacher with experience in teaching communication skills to medical students. During training the group discussed the items on the scale and in the manual to make sure that they understood the meaning of the items and the method of rating. Each rater assessed two specially designed simulated telephone calls presenting a medical problem. Then the teacher and raters compared and discussed their scoring. At the end of the training raters felt confident to handle the scale themselves.

After training, each rater received an audio tape with six (anonymised) actual conversations recorded at an (anonymised) out-of-hours centre. All personal data of the call handler and the patient were removed from the tape and this removal was checked by the manager of the centre. Inclusion criteria for these six calls were that each call should be:

- understandable: the voice of the call handler and the caller needed to be clearly audible;

- complete: the call should not be terminated suddenly, and should last no longer than 10 minutes;

- concerning a defined medical problem: the call should be about a medical problem that is commonly presented at an out-ofhours centre.

Assessments by raters involved listening to the audio tape of six conversations between callers and call handlers. They rated calls using the rating scale which was done at home. They recorded the time they needed to complete the scale for each call and the frequency of listening to the same call (completely or partly). 


\section{Practical applicability}

A second meeting was held with the raters to discuss their experiences and the results of their assessments. The 10 raters were asked whether items should be omitted or added and if items should be rephrased for better understanding or use.

\section{Results}

\section{Content validity}

The focus group agreed on the rating scale as made during the first meeting with a total of 17 items (rating scale items and the manual can be freely obtained at: www.medicinfo.info). The 17 items were divided over four obligatory phases and one intermediate period. The four phases should be present during each telephone consultation and the interruption period is optional. During the second meeting no item was added or removed. The group agreed on the description of these ratings in the manual. The two communication skills experts agreed with the consensus reached and considered the scale to be complete and valid. Their suggestions for rephrasing some items on the scale were incorporated in the rating scale. No item was removed or added.

\section{Reliability}

To calculate the results of all ratings in the pilot with 10 raters assessing six calls each, descriptive statistics were used. Cronbach's alpha was calculated as a measure of internal consistency using SPSS (version 11). Reliability (internal consistency) of the rating scale was 0.73 . Means and standard deviations for the 60 assessments are shown in Table 1. 
Table 1: Mean and Standard deviation for the 17 items of the RICE-communication list

Descriptive Statistics

\begin{tabular}{|l|r|r|r|}
\hline & $\mathrm{N}$ & \multicolumn{1}{|c|}{ Mean } & Std. Deviation \\
\hline item1 & 60 & 2,75 & 1,53 \\
item2 & 60 & 1,65 & 1,05 \\
item3 & 60 &, 73 & 1,02 \\
item4 & 60 & 2,28 & 1,52 \\
item5 & 60 & 2,57 & 1,15 \\
item6 & 60 & 1,90 & 0,88 \\
item7 & 50 & 1,72 & 1,36 \\
item8 & 30 & 1,33 & 0,71 \\
item9 & 60 & 1,45 & 1,17 \\
item10 & 40 & 1,33 & 0,83 \\
item11 & 60 & 1,68 & 0,81 \\
item12 & 30 & 2,33 & 0,80 \\
item13 & 30 & 1,90 & 0,71 \\
item14 & 60 & 1,23 & 1,28 \\
item15 & 60 & 1,90 & 1,10 \\
item16 & 60 & 1,38 & 1,15 \\
item17 & 60 & 2,18 & 0,98 \\
\hline
\end{tabular}

\section{Practical applicability}

To assess a call adequately a mean of 20 minutes (range 16-21 minutes) was needed, and all calls needed to be heard twice. Suggestions from raters about rephrasing some items of the scale were incorporated. The two training sessions with the raters lasted a total of 5 hours.

\section{Discussion}

\section{Summary of main findings}

There is increasing recognition of the need for a valid, reliable assessment tool to support training and professional development in telephone communication skills. The current researchers developed a tool which has high content validity and reliability. Results of this pilot study indicate that the tool is suitable for use in healthcare settings, such as out-of-hours centres. 


\section{Comparison with existing literature}

Although it was assumed at the start of this project that instruments to assess communication skills of primary care workers for telephone consultation were not applicable, an existing validated instrument used in the Netherlands and two other validated instruments, all developed to assess communication skills of doctors, were investigated $(3,14,17)$. Although the structure of a face-to-face consultation could be similar to a telephone consultation, specific communication skills are needed, mainly to compensate for the absence of visual contact. The existing instruments do not highlight those specific communication skills and behaviour as required for call handlers, and do not take into account that the call handler is not a doctor. They also do not provide guidance on structuring a telephone consultation.

\section{Strengths and limitations of the study}

During the focus group it was noted that each of the four stakeholder groups provided specific input. Patients in the focus group generated items concerning the way call handlers involve patients in solving their medical problems. Doctors developed items concerning the way the call handler takes the medical history of the patient. Call handlers devised items concerning the way the call handler learns to structure the telephone consultation and takes the lead in the conversation while remaining friendly, attentive, and empathic. The management team helped to produce items concerning the way a call handler handles a call within a restricted period of time, and emphasised the satisfaction of the caller.

More participants in the focus group could have influenced the composition of the scale, although it was noticed there was a redundancy effect during discussions between participants. The views of the experts confirmed this. The researchers examined ways to improve the internal consistency $(\alpha=0.73)$ of the instrument but a gain in reliability may have limited the validity of the instrument: for example, leaving out item 8 (which discusses the safety net) would give a higher a value. At the development stage, the decision was made to retain this item as all participants of the focus group felt it was important that the caller knew when to call back.

The use of inclusion criteria when selecting the six phone calls for assessment enabled the selection to be as generalisable as possible. It is possible that different criteria, a higher number of phone calls, or including some vaguely presented problems could have influenced the reliability of the results, but it is not known whether this would have given a higher or lower figure. Table 1 shows that items 2 and 3 are often not asked by call handlers (item 2 asks after or names 
the medical problem and the way it is experienced; item 3 asks for or names the expectation and personal situation). By asking these questions call handlers demonstrate that they are not only interested in the medical part of a problem, but are also interested in the personal situation of the patient; this can be considered a patientcentred approach. These skills are required if a caller presents his or her problem vaguely at the beginning of the call. The manual explains that if the caller only shares very few details about their problem, the call handler should invite the caller to elaborate on this in a polite and professional way. Sometimes patients do not make it clear what their reason is for contacting the out-of-hours service, and in this instance the call handler should assist callers in explaining their reasons for calling.

The mean of 20 minutes for call assessment was deemed acceptable. It was discovered that this period shortened once raters became more experienced at making assessments. Raters in the pilot considered the scale to be a practical instrument for assessing quality of communication skills of a peer call handler. They also noticed how much they learned about communication by making these observations.

\section{Implications for future research}

The instrument has been developed to assess the communication skills of call handlers at an out-of hours centre in the Netherlands. It will be used in a research project which will assess additional indicators for quality of telephone triage at an out-of-hours centre. The research aims to examine the quality of assessments for urgent medical problems presented by standardised patients. The instrument is in use as an instruction guideline to train call handlers to learn good communication skills.

To conclude, the aim of developing a valid, reliable, and practical instrument to assess the communication skills of call handlers at an out-of-hours centre was achieved. The instrument can be applied by colleague call handlers after training as an assessor to give call handlers feedback on their performance of handling telephone consultations with patients.

The instrument has been named the RICE rating scale. The acronym 'RICE' stands for the structure of telephone consultations according to the four successive phases: R: Reason for calling; I: Information to be gathered; C: Conclusion and care advice given; E: Evaluation of the call. As the period of interruption is not present in every telephone consultation, a character for this period is not included in this acronym. Remembering the word RICE helps the call handler to remember the sequence of the phases of a telephone call. 
This instrument is now suitable for training and quality improvement of call handlers working at out-of-hours centres and can be used in real practice. The full text of the RICE-communication manual and the RICE-communication list can be obtained freely at: www.medicinfo.info.

\section{Ethics committee}

Because the pilot did not concern an experiment with patients according to the Medical Research Involving Human Subjects Act (WMO) an ethical approval is not demanded. Therefore the demands on privacy are in accordance with the Dutch law. The privacy of the callers and call handlers was guaranteed by removing all personal related data on the six tape recorded calls. This was checked by the management of the out-of-hour centre where the calls were taped.

\section{Competing interests}

The authors' work was independent of the funders.

\section{Acknowledgements}

We thank all participants of the focus groups and all assessors of the pilot. We would also like to thank Harrie van Rooij for his continuous support. 


\section{References}

1. Silverman J, Kurtz S, Draper J. Skills for communicating with patients. Oxon: Radcliffe Medical Press Ltd, 2000.

2. Ram P, Grol R, Rethans JJ, Van der Vleuten C. Assessment of communicative and medical performance of general practitioners in daily practice. Validity, reliability and feasibility of video observation. Huisarts Wet 1999; 42(10): 439-445.

3. Kosower E, Inkelis S, Seidel J. Telephone T.A.L.K: a teaching/ assessment tool for medical training. J Biocommun 1996; 23: 22-26.

4. Patel J, Dale J, Crough R. Satisfaction with telephone advice from an accident and emergency department: identifying areas for service improvement. Qual Health Care 1997; 6(3): 140-145.

5. Maguire P, Pitceathly C. Key communication skills and how to acquire them. BMJ 2002; 325(7366): 697-700.

6. Foster J, Jessopp L, Dale J. Concerns and confidence of general practitioners in providing telephone consultations. Br J Gen Pract 1999; 49: 111-113.

7. Car J, Freeman GK, Partridge MR, Sheikh A. Improving quality and safety of telephone based delivery of care: teaching telephone consultation skills. Qual Saf Health Care 2004; 13: 2-3.

8. Car J, Sheikh A. Telephone consultations. BMJ 2003; 326:966-969.

9. Toon P. Using telephones in primary care. BMJ 2002; 24(7348): 1230-1231.

10. Moscato SR, David M, Valanis B, et al. Tool development for measuring caller satisfaction and outcome with telephone advice nursing. Clin Nurs Res 2003 12(3): 266-281.

11. Higgs R. Telephone consultation requires appropriate training. BMJ 2003, 327(7405): 53.

12. Rutenberg CD. What do we really KNOW about telephone triage? J Emerg Nurs 2000; 26(1): 76-78.

13. Griffiths M. The pros and cons of telehealth. BMJ 2002; http://www.bmj. com/cgi/eletters/324/7348/1230\#22497 (accessed 28 Mar 2007).

14. Van Thiel J, Ram P, Van Dalen J. MAAS-Global Manual 2000. The Netherlands: Maastricht University, Maastricht, 2000.

15. Rethans JJ, Norcini JJ, Baron-Maldonado M, et al. The relationship between competence and performance: implications for assessing practice performance. Med Educ 2002; 36(10): 901-909.

16. Miller GE. The assessment of clinical skills/competence/performance. Acad Med 1990; 65(9 Suppl): S63-S67.

17. Innes M, Skelton J, Greenfield S. A profile of communication in primary care physician telephone consultations: application of the Roter Interaction Analysis System. Br J Gen Pract 2006; 56:363-368. 
18. Krueger RA. Moderating focus groups. Focus group kit volume 4. Thousand Oaks CA: Sage, 1998.

19. Krueger RA. Developing questions for focus group. Focus group kit volume 3. Thousand Oaks, CA: Sage, 1998.387. 


\section{Chapter 4}

\section{Quality of clinical aspects of call handling at Dutch out-of-hours centres}

H.Derkx (1)

JJ. Rethans (2)

Arno Muijtjens (3)

B.Maiburg (1)

R.Winkens (1)

Harrie van Rooij(4)

J.A.Knottnerus (1)

(1) Department of General Practice, Maastricht University, The Netherlands

(2) Skillslab, Maastricht University, The Netherlands

(3) Department Educational Development \& Research, Maastricht University, The Netherlands

(4) Department of Quality Management primary care out-of-hours centre Tilburg, the Netherlands

Submitted for publication 


\section{Abstract}

\section{Objective}

To assess the quality of telephone triage by following the consecutive phases of its care process, the quality of the clinical questions asked about the patients' clinical condition, of the triage outcome, of the content of the home management and of the safety net advice given at out-of-hours centres.

\section{Design}

Cross-sectional national study and using telephone incognito standardized patients.

\section{Setting}

The Netherlands.

\section{Participants}

17 out-of-hours centres.

\section{Main outcome measures}

Percentages of a) clinical obligatory questions asked; b) items within home management and safety net advice, both in relation to pre-agreed standards and of c) given care advice in relation to the required care advice.

\section{Results}

Mean percentage of obligatory questions asked compared with the standard was $21 \%$. This was substantial, as it amounted to 5.6 times the standard deviation. Answers to questions about the clinical condition were not always correctly evaluated from a clinical viewpoint, either by triagists or by general practitioners. The quality of information regarding home management and safety net advice varied to a large extent and was consistently poor for all cases and for all out-of-hours centres. Triagists achieved the appropriate triage outcome in $58 \%$ of all calls.

\section{Conclusion}

In determining the outcome of the care process triagists often reached a conclusion after asking a minimal number of questions. By analysing the quality of different phases within the process of telephone triage it is possible to evaluate whether an appropriate triage outcome has been arrived at by means of good clinical reasoning or by an educated guess. In terms of enhancing the overall clinical safety of telephone triage, apart from obtaining an 
appropriate clinical history, it is also important that adequate home management and safety net advice is given.

\section{What is already known on this subject}

Research on the quality of telephone triage is often focused on the quality of the outcomes.

Little is known about the quality of the different phases of the care process of telephone triage by triagists.

\section{What the paper adds}

The results of this study identified shortcomings and educational needs regarding telephone triage which have been indicated by assessing the quality of the first phase of the process of telephone triage (asking questions and evaluating answers) and the second phase (providing care advice including home management and safety net advice). 


\section{Introduction}

Telephone triage can be described as the care process by which the degree of urgency of a clinical problem of the patient presented by telephone and the care required are determined (1). This care process can be divided into the first phase of information gathering followed by the second phase of determining the degree of urgency and the required care. The call handler, also called triagist, actually handles the request for medical advice. In most cases this person is a specially trained nurse, or a physician (2). The quality of telephone triage depends on the clinical knowledge and the communication skills of the triagist and their expertise in evaluating the information gathered (3).

The safety of the advice given by triagists is frequently questioned (4-6) and most studies on the quality of telephone triage have focused on analysis of the triage outcomes (7-13). However, in order to assess the safety of telephone triage with more accuracy the quality of the care process itself needs to be analyzed. This includes assessment of the clinical quality of questions asked as well as the evaluation of the answers and the care advice given. For instance, if the triage outcome is assessed in isolation, the possibility of achieving a clinically acceptable outcome by chance may not be detected. Conversely a clinically acceptable triage outcome might not occur due to incorrect interpretation of the information gathered (14), even though the consultation process itself was carried out correctly. When the patient does not receive appropriate information regarding home management or safety net advice, inappropriate self care and delay in seeking medical care might occur (15).

We could not identify studies that investigated the safety of telephone triage by assessing the quality of each phase of the process of telephone triage. Therefore the objective of this study was to make a global assessment of the quality, specifically the quality of the clinical questions asked, the evaluation of the answers, the triage outcomes, and the content of the home management and safety net advice in telephone consultations carried out by triagists at out-ofhours $(\mathrm{OOH})$ centres in the Netherlands. 


\section{Method}

To assess the quality of clinical case handling at $\mathrm{OOH}$ centres Telephone Incognito Standardised Patients (TISPs) presented seven different clinical cases three times to 17 different $\mathrm{OOH}$ centres over a period of 12 months adding to a total number of 357 calls.

\section{Cases, protocols and scenarios}

For the selection of cases the following criteria needed to be applied: 1) the cases were to be based on symptoms that are known to present frequently on the telephone to $\mathrm{OOH}$ centres $(7,16) ; 2)$ the care advice as outcome of the telephone consultation needed to be straightforward. In the Netherlands the triagist can select different triage outcomes depending on the degree of urgency: immediate and very urgent care (to be seen within 1-2 hours), urgent care (within 2-6 hours), routine care (care by a general practitioner the next day) or self care advice. 3) For this study it was decided that no case would require an outcome of immediate care or a home visit for practical reasons. 4) The cases were designed to demonstrate the importance of accurate history taking so that it could be shown whether the correct outcome had been determined by asking the required questions. Therefore six of the seven cases to be presented consisted of three sets of two almost identical cases. For each of these parallel pairs of cases only one answer to an obligatory question differed (this was called the discriminating answer).

In Table 1 the scenario's for case 6 and 7 to be played by the TISP with the discriminating answers are presented. In Table 2 the discriminating answer for case 2 and 3 and case 4 and 5 are described.

In order to use up-to-date protocols (17), the research team decided to revise existing national protocols as these were four years old. When these were developed there was very little experience in the Netherlands with $\mathrm{OOH}$ services and with triagists (non-clinicians) handling all incoming calls. Protocols for telephone triage include not only questions about possible causes and the consequences of the symptom presented but also questions to compensate for the lack of visual information about a patients' clinical condition (18). They also include advice about home management care to be given if the triage outcome does not include a face-to-face consultation (e.g. type and dose of analgesic medication). Finally they include advice about the circumstances when the patient should call back ('safety net advice') (19-21).

To reach consensus and achieve standardisation for this study these protocols were presented to a protocol-panel of general practitioners 
(GPs) with experience in telephone triage at $\mathrm{OOH}$ centres. They agreed on the obligatory questions that should be asked regarding the different clinical symptoms and what should be discussed with the patient in relation to home management and safety net advice.

Telephone Incognito Standardised Patients (TISPS)

Lay persons have been used as "unannounced" or Incognito Standardised Patients (ISPs) for many years to assess the performance of students and health care professionals during faceto-face and telephone consultations. There is evidence that the ISP-methodology is a reliable and valid instrument to assess clinical performance (22-25).

The cases were presented by special trained TISPs. They received a scenario with information on their personal data, the clinical problem, their personal situation (e.g. feeling anxious) and the answers to be given to the obligatory questions if they were asked. If they were invited to come for a consultation at the $\mathrm{OOH}$ centre, they were instructed to ask for the reason for this request. Another panel of GPs validated the scenarios and considered them realistic and representative of cases that might present to $\mathrm{OOH}$ centres. No additional obligatory questions were needed to determine clinical urgency. They agreed that it was reasonable for TISPs to receive self care advice for case 1,2, 4 and 6 and to be advised to be seen the same evening for case 3, 5 and 7 .

To increase the chances of speaking to different triagists the TISPs called in the evening between 7 and $9 \mathrm{pm}$ on different days of the week. They made the calls from their private home pretending to be in the area of the involved $\mathrm{OOH}$ centre. They self audio recorded the calls for further assessment.

\section{Out-of-hours centres}

In October $2004105 \mathrm{OOH}$ centres were operative in the Netherlands. All centres were asked for permission to be selected for the research study. Of the 98 centres that gave permission, we selected $17 \mathrm{OOH}$ centres about we did not inform them. We performed a balanced selection where for each of the 12 provinces of the Netherlands the size of the population in that province determined the number of $\mathrm{OOH}$ centres to be selected. These centers were then selected at random ${ }^{1}$.

After the study the $17 \mathrm{OOH}$ centres were asked by letter whether they had detected a TISP during the last 12 months.

1 Ethical approval: Under Dutch law no ethical approval is needed to phone or to record calls made by a standardised patient to an out-of-hours centre once permission has been given by the management of the $\mathrm{OOH}$ centre. 


\section{Assessment and analysis}

The required frequency of presentation of the cases developed was based on a generalisability analysis. In a first batch the seven cases were presented five times to five of the 17 selected $\mathrm{OOH}$ centres. The results on the assessments of these calls demonstrated that for a reliable overall assessment of quality each of the seven cases was to be presented three times and two assessments per call were needed (23-26). Therefore the remaining $12 \mathrm{OOH}$ centres were called three times for the same seven cases.

A transcript was made of every recorded call and each call was assigned to two medical students as raters. They scored calls independently by using the standard protocol as a checklist. They rated each item by marking "Yes (=1: Question is asked/ Advice is given)" or "No (=0: Question is not asked/ Advice is not given)".

For each call the following variables were obtained as indicators of quality:

1. percentage of obligatory questions asked in relation to the agreed standard set of questions;

2. percentage of items within home management and safety net advice in relation to the agreed standard set of items;

3. percentage of obligatory questions asked in relation to all questions asked;

4. percentage of appropriate care advice in relation to the required care advice.

For each of these variables the average percentage of the two raters were used for further analysis per case for all $\mathrm{OOH}$ centres and per $\mathrm{OOH}$ centre for all cases.

For the variables of percentage obligatory questions and percentage home management and safety net advices we measured the difference compared to an ideal value of $100 \%$ (100\% indicating: all obligatory questions were asked, and all required home management and safety net advices was given). For each variable an analysis of variance was performed with case and $\mathrm{OOH}$ centre examined as factors in separate analyses. The significance of the F-test for the intercept indicates whether the overall mean of the variable differs from $100 \%$, and the significance of the F-tests for the factors case and $\mathrm{OOH}$ centre indicates whether the mean value of the variable varies significantly. A p-value of 0.05 or smaller was considered to indicate statistical significance.

In addition, the magnitude of the difference of the overall mean with an ideal value of $100 \%$ was represented by an effect-size-like measure: 100\%-overall mean / overall standard deviation.

Descriptive statistics and results of the analysis of variance were obtained by using the statistical software package SPSS vs.15. 


\section{Results}

For $58 \%$ of all calls the required urgency level was advised as was set by the scenario-panel. There was an underestimate of urgency in $41 \%$ and an overestimate of urgency in $1 \%$ of all calls.

Figure 1 shows the results of the distributions for the variables of obligatory questions (upper part) and home and safety advices (lower part) analysed for three purposes: overall, per case and per $\mathrm{OOH}$ centre.

For each variable three panels with boxplots are shown: the left panel shows the distribution for all calls $(n=357)$, the middle panel the distributions per case (51 calls per boxplot), and the right panel the distributions per $\mathrm{OOH}$ centre (21 calls per boxplot). The boxplots show the mean value (solid line), the 25 -th and 75 -th percentiles (lower and higher boundaries of the grey box) to indicate the central part, and the 10-th and the 90-th percentiles (grey "whiskers" outside the box) to indicate the outer parts of the distribution.

The analysis of variance for percentage obligatory questions showed that the overall mean was equal to $21 \%$, significantly different from the ideal $100 \%(F(1,13)=1234, p<0.0005)$, and it amounted to a large difference (5.6 times the standard deviation). The variation for obligatory questions across case as well as across $\mathrm{OOH}$ centre was shown to be statistically significant $(F(6,334)=7.3, p<0.0005$, and $F(16,334)=5.6, p<0.0005$, respectively).

For percentage home and safety net advice the overall mean, $40 \%$, was found to be significantly different from the ideal $100 \%$ $(F(1,6)=172, p<0.0005)$ and it amounted to 2.6 times the standard deviation. The variation across case was found to be significant $(F(6,318)=17.9, p<0.0005)$ and for $\mathrm{OOH}$ centre it was found to be of borderline significance $(F(16,318)=1.7, p=0.051)$.

Table 3 shows per case the number of questions (advices) in the ideal standard set, mean and standard deviation of the obligatory questions asked versus the standard, and of the home management and safety net advice provided versus the standard. In addition Table 3 shows the mean of the obligatory questions among all questions asked, and the mean of the appropriate advice given versus the required advice. Table 4 shows the same variables for each of the $17 \mathrm{OOH}$ centres.

Figure 1 demonstrates the difference in performance between individual triagists at the same $\mathrm{OOH}$ centre. Some of them asked many obligatory questions, others asked none. Some managed a score of almost $90 \%$ for relevant home management and safety net advice, others gave none at all. 
The same triagist handled the same case twice in $3 \%$ of the calls; all other calls were handled by different triagists. The triagists referred $2 \%$ of the TISPs to the $\mathrm{OOH}$ centre in the region of their permanent residence without any triage. None of the $17 \mathrm{OOH}$ centres indicated that they had detected any call made by a TISP.

For 153 calls the required care advice resulting from the telephone triage was to come to the $\mathrm{OOH}$ centre. This care advice was given on 17 occasions. On six occasions triagists suggested that the reason why the patient needed to be seen at the $\mathrm{OOH}$ centre the same evening was the use of anti-malaria-treatment and on four occasions because of a travel to an African country. For seven urgent care outcomes no clinical reason could be identified.

GPs returned a call on six occasions to a TISP acting as an adult with fever (case 5) in which the TISP mentioned the usage of Malarone. The outcome of these return calls was self care advice on four occasions and on two occasions the TISP was advised to be seen the same evening for further assessment (the reason given was: "We have to exclude malaria as the cause of your fever".) 


\section{Discussion}

Summary of main findings

The results of this study identify shortcomings and educational needs regarding telephone triage which have been indicated by assessing the quality of phase one (asking appropriate questions and evaluating the answers) and two (care advice) of the process of telephone triage. The mean score for obligatory questions asked was $21 \%$ of the agreed standard and the difference from $100 \%$ score was also found to be substantial, as it amounted to 5.6 times the standard deviation. Answers to obligatory questions were not always evaluated clinically correctly. The quality of the information given regarding home management and safety net advice was also consistently below the standard, but in addition varied considerably per case and per $\mathrm{OOH}$ centre. The appropriate triage outcome was reached in only $58 \%$ of all calls.

\section{Strength and weaknesses}

It is known that triagists respond very accurately to cases of high urgency but not to moderate and low urgency cases such as those presented in this study (27). Our study shows an underestimate of urgency in $41 \%$ and an overestimate of urgency in $1 \%$ which is in line with other results $(12,28)$. However, our design using sets of parallel cases with a discriminating answer demonstrates that by assessing only triage outcomes, incorrect conclusions regarding the safety of telephone triage might be drawn, even if the correct outcome is determined.

Since none of the $17 \mathrm{OOH}$ centres had detected any of the TISPs and different triagists handled $97 \%$ of all calls we conclude that this study reflects the day to day performance of call handling at those centres.

Cases, protocols and scenarios

Some members of the scenario-panel considered case 2 (adult with nose bleeding) as likely to be a frequently presented case but case 3 (as case 2 but with bruises) as quite uncommon. We decided to present this case as it is an example of an uncommon, but potentially life threatening (29-30) symptom which can be dealt with safely by adequate triage.

In our study many obligatory questions remained unasked and triagists often asked questions that the protocol and scenario panels did not consider as required to be asked to determine an urgency level. This means that for telephone triage history taking was 
frequently not carried out effectively.

Research revealed that triagists often ask a few questions (31-35) and do not use or follow protocols. The safety of any care process is likely to be improved by following protocols, but little is known to what extent improvement might occur. In our study the analysis of variance for obligatory questions asked compared with the standard showed that the overall mean significantly and substantially differed from $100 \%$. Although agreed standards are seldom met, we conclude that the number of obligatory questions asked at the different $\mathrm{OOH}$ centres was far too low to determine a clinical urgency.

Triagists at $\mathrm{OOH}$ centre $\mathrm{nr} 5$ asked significantly more obligatory questions for all cases than at any other centre. However, this did not result in a higher number of appropriate outcomes than at the other centres. The reason for this would require further investigation.

An example of misinterpretation of an answer took place on a Friday evening when the triagist of a $\mathrm{OOH}$ centre said to the TISP with nose bleeding (case 3); “ You'd better see your doctor next week because you said you have a bleeding nose and several bruises, so there might be something wrong with your blood".

Our findings on (mis-)interpretation of answers by triagists and GPs confirm that in addition to asking the right questions understanding the relevance of the answers is equally important.

Triagists gave a small amount of home management and safety net advice relevant to the nature of the clinical problem presented. Further research is needed to investigate whether triagists are aware of the importance of this advice, especially if a self care advice is given. 


\section{Conclusion}

Triagists appeared to carry out a rapid clinical scan before they came to a conclusion without considering in sufficient detail different causes for a symptom or its possible consequences. Even when the triagist gave the required self care advice, for nearly all calls this choice could be considered to be the correct choice only by means of educated guess as so few obligatory questions were asked. This study also demonstrates that triagists should ideally only recommend a low urgency level of care after thorough history taking. The quality of information regarding home management and safety net advice varied to a large extent and was consistently low per case and per $\mathrm{OOH}$ centre.

\section{Implications for further research}

Telephone triage should aim at minimising risks to a patients' health. The safety of telephone triage might be enhanced by using computer based decision support systems $(1,36)$. Based on the findings of this study it appears that such a program should have as a minimum requirement protocols with advice on obligatory questions to be asked, recommendations for urgency outcome and relevant home management and safety net advice. Little is known about the conditions in which these systems are to be used (37-38). Accordingly, research is needed on design and implementation of these systems to support telephone triage effectively and safely.

\section{Acknowledgements}

We would like to express our gratitude to Ron Hoogenboom for patiently helping with the statistical analysis of all data. 


\section{TABLES}

Table 1. Case 6 and 7 and the answers to questions to be given if asked

\section{Opening by caller;}

"Good evening. I have a question. My son vomited a few minutes ago. I have some paracetamol. Should I give it to him?"

Answers only to be given when asked:

- Onset

- Behaviour of child

- Frequency of vomiting

- Vomited blood

- Diarrhoea

- Abdominal pain

- Dehydration

$\circ$ Drinking

$\circ$ Micturation

- Rash

- Fever

- Headache

- Earache

- Stiff neck

- Head injury

- Wrong food

- Medical past

- Family

- Self care
3 hours ago ( around $5 \mathrm{pm}$ ) and at

$6.30 \mathrm{pm}$ and a few minutes ago normal

$3 x$

no

no

no

drank normally last few hours

1 hour ago; no pain

no

no

yes, complained of a slight headache

no

no

\section{${ }^{1}$ CASE 6; NO}

1 CASE 7: YES: thank you for asking me. You have reminded me that this afternoon, he fell while he was playing. He cried a lot. I also noticed a swelling at the back of his head. no

no

no, no one else is ill none 
Table 2: Discriminating answer for each pair of parallel cases

\begin{tabular}{|clll|}
\hline Case & Age & Clinical Problem & Discriminating answer \\
\hline 1 & 5 years & Fever & Not applicable \\
2 & adult & Nose bleed & None \\
3 & adult & Nose bleed & Noticed several bruises past few \\
& & & hours \\
4 & adult & Fever & None \\
5 & adult & Fever & Irregular usage of anti-malaria \\
& & & drugs last 2 weeks \\
6 & 5 years & Vomiting & None \\
7 & 5 years & Vomiting & Had a head injury a few hours ago \\
\hline
\end{tabular}




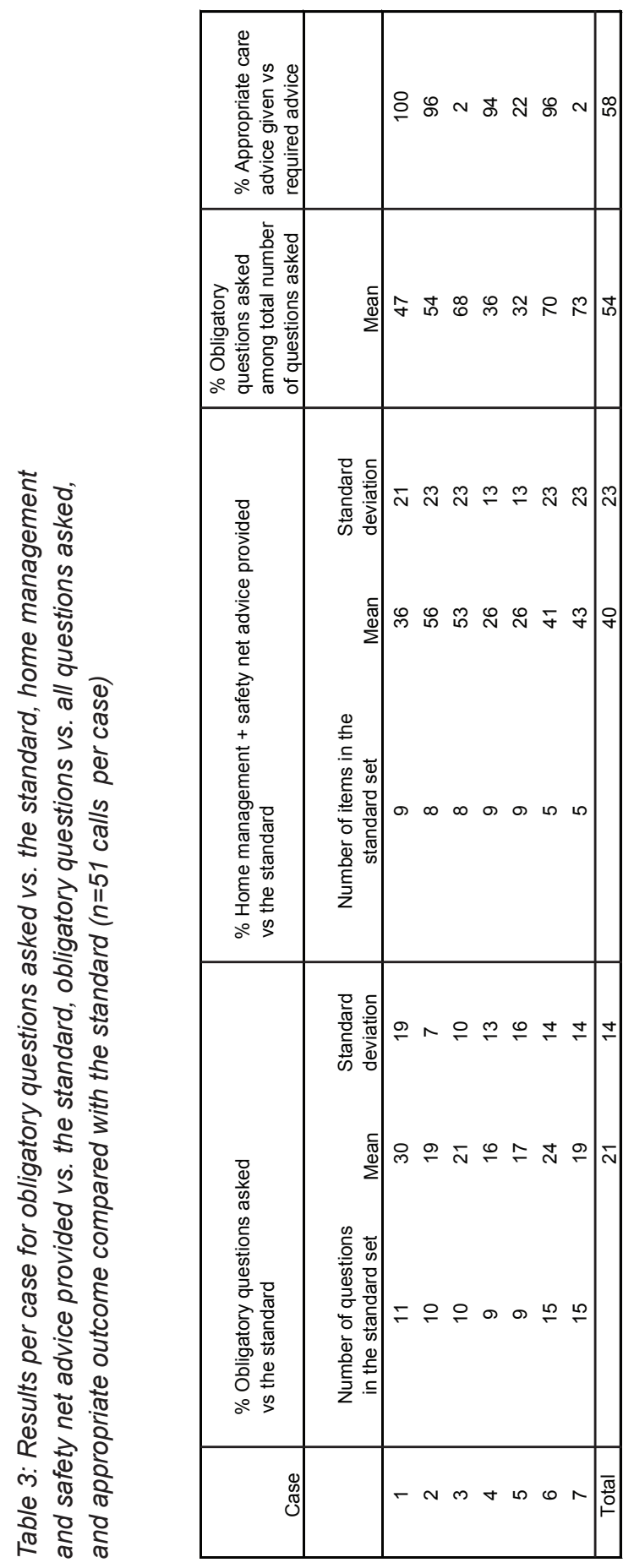




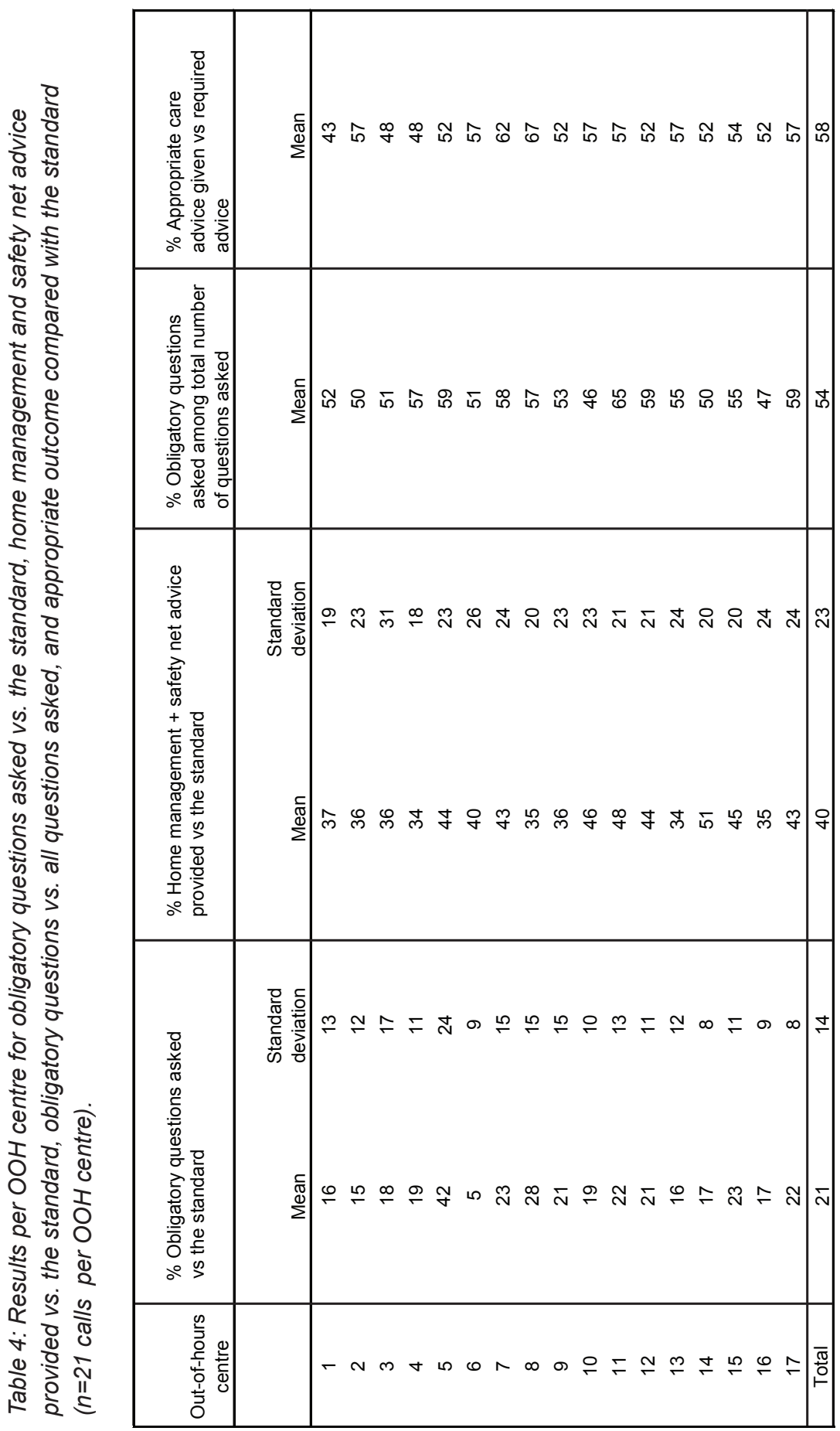




\section{LEGENDS}

Figure 1. Boxplots (distributions) of variables percentage obligatory questions asked vs. standard (upper part), and percentage home management and safety advices provided vs. standard (lower part). Per variable three panels are shown: the left panel presents the distribution for all calls ( $N=357)$, the middle panel the distributions per case (51 calls per boxplot), and the right panel the distributions per $\mathrm{OOH}$ centre $(21 \mathrm{calls}$ per boxplot). Each boxplot shows the mean value (solid line), the 25-th and 75-th percentiles (lower and higher boundaries of the grey box) indicating the central part, and the 10-th and the 90-th percentiles (grey "whiskers" outside the box) indicating the outer parts of the distribution.
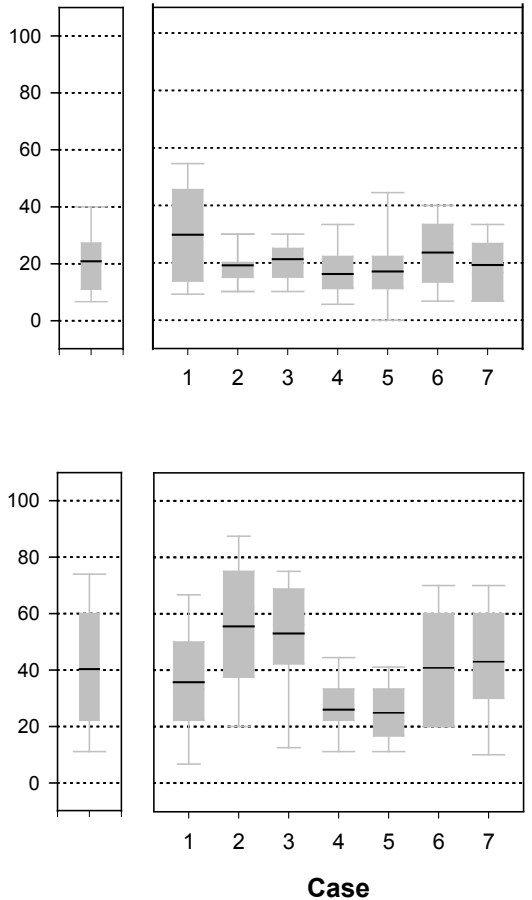
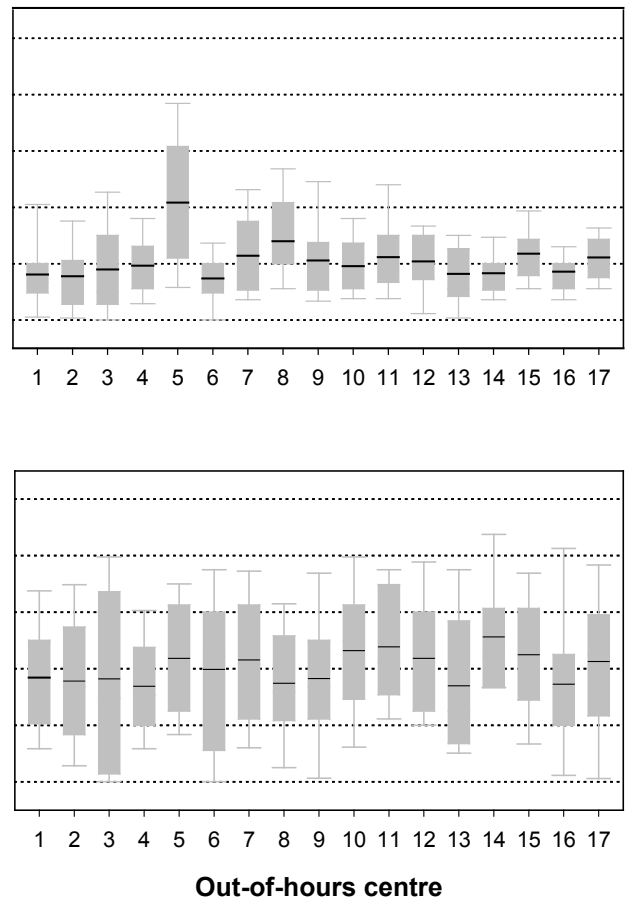


\section{References}

1. Crouch R. An investigation onto effects of a computer based decision support program on Accident and Emergency nurses'assessment strategies in telephone consultation Thesis. 2000 University of Surrey.

2. Christensen MB, Olesen F.Out of hours service in Denmark: evaluation five years after reform. BMJ 1998 May 16;316(7143):1502-5.

3. Yanovski SZ, Yanovski JA, Malley JD, Brown RL, Balaban DJ. Telephone triage by primary care physicians. Pediatrics 1992 Apr;89 (4 Pt 2):701-6.

4. Giesen P.Quality of out-of-hours care in the Netherlands. Thesis. UMC St Radboud Nijmegen 2007

5. Foster J, Jessopp L, Dale J. Concerns and confidence of general practitioners in providing telephone consultations. Br J Gen Pract. 1999 Feb;49(439):111-3.

6. Car J, Freeman G, Partridge M, Sheikh A. Improving quality and safety of telephone based delivery of care: teaching telephone consultation skills. Qual Saf Health Care 2004 Feb;13(1):2-3. Editorial.

7. Post J. Large scale primary care service during after-hours (Grootschalige huisartsenzorg buiten kantooruren). Thesis, University of Groningen, The Netherlands, Groningen 2004.

8. Fatovich DM, Jacobs IG, McCance JP, Sidney KL, White RJ. Emergency department telephone advice. Med J Aust 1998; 169:143-146.

9. Belman S, Chandramouli V, Schmitt BD, Poole SR, Hegarty T, Kempe A. An assessment of pediatric after-hours telephone care: a 1-year experience. Arch Pediatr Adolesc Med 2005 Feb;159(2):145-9.

10. Light PA, Hupcey JE, Clark MB. Nursing telephone triage and its influence on parents' choice of care for febrile children. J Pediatr Nurs 2005 Dec;20(6):424-9.

11. Crouch R, Patel A, Williams S, Dale J. An analysis of telephone calls to an inner-city accident and emergency department. J R Soc Med 1996 Jun;89(6):324-8.

12. Wahlberg AC, Wredling R. Telephone nursing: calls and caller satisfaction. Int J Nurs Pract 1999 Sep;5(3):164-70.

13. Salisbury C, Trivella M, Bruster S. Demand for and supply of out of hours care from general practitioners in England and Scotland: observational study based on routinely collected data. BMJ 2000 Mar 320(7235): 618-21.

14. Chowdhury S. The Power of Six Sigma. Pearson Education Ltd 2001, Prentice Hall.

15. Silverman J, Kurtz S, Draper J. Skills for communicating with patients.

Oxon: Radcliffe Medical Press Ltd, 2000. 
16. Dale J, Williams S, Crouch R, Patel A. A study of out-of-hours telephone advice from an A\&E department. Br J Nurs 1997 Feb 1326;6(3):171-4.

17. Dutch Society of General Practitioners; Telephone guideline book Dec. 2007. Utrecht (NHG Telefoonwijzer).

18. Edwards B. Seeing is believing--picture building: a key component of telephone triage. J Clin Nurs 1998 Jan;7(1):51-7.

19. Derkx HP, Rethans J-J E, Knottnerus JA, Ram P. Assessing communication skills of clinical call handlers working at an out-of-hours centre. The development of the RICE rating scale. Br J Gen Pract 2007 May;57 (538):383-7.

20. Neighbour R. The inner consultation: how to develop an effective and intuitive consulting style. 1987 M.T.Press, Lancaster.

21. Rapid Responses to: Telephone consultations. (Car J., Sheikh A.) Higgs R., BMJ 2003; 326: 966-969

22. Rethans JJ, Gorter S, Bokken L, Morrison L. Unannounced standardized patients in real practice: a systematic literature review. Med Educ 2007 Jun;41(6):537-49.

23. Van der Vleuten C, Swanson D. Assessment of clinical skills with standardized patients: state of the art. Teaching and Learning in Medicine 1990;2:58-76.

24. Rethans JJ, Norcini JJ, Baron-Maldonado M, Blackmore D, Jolly BC, LaDuca T, Lew S, Page GG, Southgate LH. The relationship between competence and performance: implications for assessing practice performance. Med Educ 2002 Oct;36(10):901-9.

25. Moriarty $H$, McLeod $D$, Dowell $A$. Mystery shopping in health service evaluation. Br J Gen Pract 2003 Dec;53(497):942-6.

26. Ram P, Grol R, Rethans JJ, Van der Vleuten C. Assessment of communicative and medical performance of general practitioners in daily practice. Validity, reliability and feasibility of video observation. Med Educ 1999;33:447-454.

27. Leprohon J, Patel VL. Decision-making strategies for telephone triage in emergency medical services. Med Decis Making 1995 JulSep;15(3):240-53.

28. Lattimer V, George S, Thompson F, Thomas E, Mullee M, Turnbull J, Smith $\mathrm{H}$, Moore M, Bond $\mathrm{H}$, Glasper A. Safety and effectiveness of nurse telephone consultation in out of hours primary care: randomised controlled trial. The South Wiltshire Out of Hours Project (SWOOP) Group. BMJ 1998 Oct 17;317(7165):1054-9. 
29. Parkin JD, Smith IL, O'Neill AI, Ibrahim KM, Butcher LA. Mild bleeding disorders. A clinical and laboratory study. Med J Aust 1992 May 4;156(9):614-7.

30. Viehweg TL, Roberson JB, Hudson JW. Epistaxis: diagnosis and treatment. J Oral Maxillofac Surg 2006 Mar;64(3):511-8.

31. Aitken $M$. Telephone advice about an infant given by after-hours clinics and emergency departments. NZ Med J 1995; 108:315-317.

32. Carbajal R, Barthez P, Blanc P, Paupe A, Lenclen R, Olivier-Martin M, Simon N. Telephonic advice by an emergency department given in a simulated pediatric case. Arch Pediatr 1996 Oct; 3(10):964-8.

33. Tijssen R. De "NHG-Telefoonwijzer": een goede leidraad voor triage? 2004 Nijmegen. Faculty of Medicine.UMC 045125.

34. Belman S, Murphy J, Steiner JF, Kempe A. Consistency of triage decisions by call center nurses. Ambul Pediatr 2002 Sep-Oct;2(5): 396-400.

35. Fatovich DM, Jacobs IG, McCance JP, Sidney KL, White RJ. Emergency department telephone advice. Med J Aust 1998; 169:143-146.

36. Dale J, Williams S, Foster T, Higgins J, Snooks H, Crouch R, HartleySharpe C, Glucksman E, George S. Safety of telephone consultation for "non-serious" emergency ambulance service patients. Qual Saf Health Care 2004 Oct;13(5):363-73.

37. Grol R. Beliefs and evidence in changing clinical practice. Personal paper BMJ 1997;315:418-21.

38. Kawamoto K, Houlihan CA, Balas EA, Lobach DF. Improving clinical practice using clinical decision support systems: a systematic review of trials to identify features critical to success BMJ $2005 \mathrm{Apr}$ 2;330(7494):765. Epub 2005 Mar 14. 


\title{
Chapter 5
}

\section{Quality of communication during telephone triage at Dutch out-of-hours centres}

\author{
H.Derkx (1) \\ JJ. Rethans (2) \\ Arno Muijtjens (3) \\ B.Maiburg (1) \\ R.Winkens (1) \\ Harrie van Rooij(4) \\ J.A.Knottnerus (1)
}

(1) Department of General Practice, Maastricht University, The Netherlands
(2) Skillslab, Maastricht University, The Netherlands
(3) Department Educational Development \& Research, Maastricht University, The Netherlands
(4) Department of Quality Management primary care out-of-hours centre Tilburg, the Netherlands

Submitted for publication 


\section{Abstract}

\section{Objective}

To assess the quality of communication skills of triagists, working at out-of-hours $(\mathrm{OOH})$ centres, and to determine the correlation between the communication score and the duration of the telephone consultation.

\section{Methods}

Telephone Incognito Standardised Patients (TISPs) called $17 \mathrm{OOH}$ centres presenting different clinical cases. The assessment of communication skills was carried out using the RICE-communication rating list. The duration of each telephone consultation was determined.

\section{Results}

The mean overall score for communication skills was $35 \%$ of the maximum feasible. Triagists usually asked questions about the clinical situation mostly correctly and little about the patients' personal situation, perception of the problem or expectation. Advice about the outcome of triage and self care advice was usually given without checking for patients' understanding and acceptance of the advice. Calls were often handled in an unstructured way, without summarizing or clarifying the different steps within the consultation. There was a positive correlation of $0.86(p<0.01)$ between the overall communication score and the duration of the telephone consultation.

\section{Conclusion}

Assessment of communication skills of triagists revealed specific shortcomings and learning points to improve the quality of communication skills during telephone triage.

\section{Practice implications}

Training in telephone consultation should focus more on patientcentred communication with active listening, active advising and structuring the call. Apart from adequate communication skills, triagists need sufficient time for telephone consultation to enable high quality performance. 


\section{Introduction}

Communication between doctors and patients has changed during the last few decades due to social shifts in our society. In the past communication focussed on the disease process, whereas nowadays communication is increasingly patient-centred (1-4).

The disease is no longer the main point of discussion but the communication is centered on the patient who feels unwell. The need for good communication skills in telephone triage is also recognised (5-8). Telephone triage can be described as the care process by which the degree of urgency of the clinical problem and care required are determined (9). The call handler actually handles the request for medical advice. In most cases this person is a specially trained nurse, or sometimes a physician (10). The term used to describe this person is a 'triagist'. The quality of the telephone triage depends on the clinical knowledge and the communication skills of the triagist.

Patients' satisfaction with telephone consultations involving out-ofhours $(\mathrm{OOH})$ centres is often related to the triagist being able to provide reassurance and the fact that the caller feels to have received adequate time to allay concerns (11-13). Patients' dissatisfaction with telephone consultation is often due to the lack of acknowledgement of physical or emotional needs or to not meeting patients' expectations $(14,15)$.

Although the need for good communication skills in telephone consultations is recognised, little is known about the quality of communication skills of triagists working at $\mathrm{OOH}$ centres. Therefore, in this study this subject is investigated.

Research on the quality of communication of general practitioners (GPs) in face-to-face contacts suggests that the duration of a consultation correlates positively with the quality of the communication (16-18). In the current study the relation between the duration of the call and the quality of communication skills of triagists of $\mathrm{OOH}$ centres is investigated. 


\section{Methods}

\subsection{Telephone Incognito Standardised Patients (TISPs)}

Lay persons have been used as "unannounced" or Incognito Standardised Patients (ISPs) for many years to assess the performance of medical students and health care professionals during face-to-face consultations. There is evidence that the ISPmethodology is a reliable and valid instrument to assess clinical performance (19-22).

The research team trained 14 Telephone ISPs (TISP) to portray seven different clinical cases on the telephone. They had to use the opening and closing sentence as prescribed and to give information only if questions were asked. When the TISP was given a self care advice the closing sentence was: "Are you sure I don't need to be seen by a doctor?". When the TISP was asked to visit the $\mathrm{OOH}$ centre the closing sentence was; "Are you sure I have to come and why?"

The TISPs were trained to express in an audible way that they were unsure about the care advice. All calls were made at home and self recorded by the TISPs for further assessment and in order to register the names of the triagists. A TISP made four to five calls per evening. Accuracy of their role playing amounted to $100 \%$.

\subsection{Out of hours centres}

In October $2004105 \mathrm{OOH}$ centres were operative in the Netherlands. All $\mathrm{OOH}$ centres were asked for permission to be selected for the research study. Of the 98 centres that gave permission 17 centres were selected. The selection comprised was a balanced selection where for each of the 12 provinces of the Netherlands the size of the population in a province determined the selection of one to three $\mathrm{OOH}$ centres at random 1 .

The objective of this study was to investigate the overall quality of the communication skills at an $\mathrm{OOH}$ centre. Therefore we needed case handling preferably by different triagists. To enhance this the TISPs called between 7 and $9 \mathrm{pm}$ at different days of the week. After the study the $17 \mathrm{OOH}$ centres were asked whether they had any indication that they had been called by a TISP during the last 12 months.

\subsection{Cases}

The research team developed seven clinical cases. The scenarios for these cases were assessed by a panel of GPs as being representative

1 Ethical approval: Under Dutch law no ethical approval is needed to phone or to record calls made by a standardised patient to an out-of-hours centre once permission has been given by the management of the $\mathrm{OOH}$ centre. 
for calls made to an $\mathrm{OOH}$ centre. The GPs made recommendations for care advice that was appropriate for each case. Case 1 was a case of a child of 5 years old with fever; case 2 and 3: an adult with a nose bleeding; case 4 and 5: an adult with fever; case 6 and 7: a child of 5 years old with vomiting. The last six cases included sets of two parallel pair of cases which differed only in the answer to one question (if asked). This design was needed as these cases were also used to assess the clinical quality of case handling. The seven cases were presented three times to each of the selected $17 \mathrm{OOH}$ centres.

\subsection{Assessment of communication skills}

An instrument was developed to assess communication skills for clinical problems presented by telephone (23). This instrument is called the RICE-communication list (the acronym RICE stands for Reason for calling, Information gathered, Care advice and Evaluation of the call) (RICE-communication list: see addendum). A team of 11 assessors with experience in working as triagists was trained to assess the quality of telephone communication skills, using the RICE-communication list. The assessors received a copy of the recorded call on a CD and a transcript of the conversation. Each call was assigned at random to two assessors and assessed independently.

To evaluate the results of the assessments the items of the RICEcommunication list were ordered in three clusters and nine sub clusters:

Cluster Sub cluster

1.Active listening

1. Personal situation

2. History taking

3. Reaction to (non-)verbal signals

2. Active advising

4. Home management and safety net advice

5. Checking for understanding and acceptance of advice

3. Structuring

6. Personal data

7. Concluding the consultation

8. Interruption

9. Summarizing and announcing different phases 
For content validation this ordering of items was presented to two experts in communication skills. They agreed upon the proposed arrangement of the items in the clusters and sub clusters. After the development of the RICE-communication list its reliability (internal consistency) was investigated by presenting 6 calls to 10 assessors (23). The results of these assessments were used to determine the number of assessors required per call for a reliable assessment of the sub clusters. The result of a generalisability analysis indicated that two assessors were required per call in order to reach a generalisability coefficient above 0.8 per cluster (20).

\subsection{Statistics}

The required frequency of presentation of the cases developed was based on another generalisability analysis. In a first batch the seven cases were presented five times to five of the 17 selected $\mathrm{OOH}$ centres. The results on the assessments of these calls demonstrated that for a reliable overall assessment of quality each of the seven cases was to be presented three times $(16,20)$. Therefore the remaining $12 \mathrm{OOH}$ centres were called three times for the same seven cases.

The two assessors average score on the items of the RICEcommunication list were used in subsequent analysis of the data. The mean score for each cluster and sub cluster as a percentage of the maximum feasible score was calculated for all calls per $\mathrm{OOH}$ centre.

The duration of the telephone consultation was correlated with the overall communication score (Pearson correlation). Descriptive statistics and results of the analysis of variance were obtained by using the statistical software package SPSS version 15. 


\section{Results}

A total number of 357 calls were assessed. They were handled by 285 different triagists. None of the $17 \mathrm{OOH}$ centres detected that any call had been made by a TISP.

The results of the assessments of the seven cases for each cluster and sub cluster are presented per $\mathrm{OOH}$ centre in Table 1.

Figure 1 (boxplots) shows the results of the distributions for the mean percentage for the variables for clusters 1, 2 and 3 (upper part) over calls in two ways: overall and per $\mathrm{OOH}$ centre.

For each variable two panels with boxplots are shown: the left panel shows the distribution for all calls $(\mathrm{N}=357)$ and the right panel the distributions per $\mathrm{OOH}$ centre (21 calls per boxplot). The boxplots show the mean value (solid line), the 25 -th and 75 -th percentiles (lower and higher boundaries of the grey box) to indicate the central part, and the 10-th and the 90-th percentiles (grey "whiskers" outside the box).

The mean overall communication percentage score for all cases at all $\mathrm{OOH}$ centres was $35 \%$ of the maximum feasible score, varying from 28 to $45 \%$. There was a significant variance of scores across the $\mathrm{OOH}$ centres for most sub clusters. The mean overall score on the nine sub clusters ranged from $68 \%$ for the way of history taking to $17 \%$ concerning checking for understanding and acceptance of the care advice given.

The mean duration of all calls was 201 seconds, ranging across the $\mathrm{OOH}$ centres from 157 to 267 seconds. The correlation between the duration of the telephone consultation and the overall communication score was $0.86(p<0.01)$. 


\section{Discussion and Conclusion}

\subsection{Discussion}

The results for cluster 1 and 2, active listening and active advising, correspond with the observed criticisms of communication skills of doctors during telephone and face-to-face consultations (24). In telephone consultations doctors have shown that they ask principally for medical information and less psychosocial or affective information is obtained than in face-to-face contacts. In our study triagists did not often elicit the concerns of the patient and obtained little information about patients' perception of the problem or about the physical, emotional or social impact of the problem. In face-toface consultations doctors often give information without checking the patients' understanding (1). Our study shows similar findings in telephone consultations by triagists.

Research on face-to-face consultations and quality of performance by GPs has shown that practices with longer consultation times enable patients to express more details regarding their problems. A short consultation can merely be seen as an encounter with some social interaction enabling a contact and to give advice (16). In this study a significantly positive correlation was found between the length of the telephone consultation and the quality of the communication but research is needed to determine the acceptable duration required for calls that enables effective and high quality communication.

As a total number of $80 \%$ of all calls were handled by different triagists and no calls were unmasked, we conclude that our study reflects the day to day performance on communication at those centres.

We took a sample of 17 out of the $98 \mathrm{OOH}$ centres which had given permission to be called. Even though there are minor organisational differences between Dutch $\mathrm{OOH}$ centres basically they work in the same way (25). The relatively small variation over the $\mathrm{OOH}$ centres of the communication quality variables cluster 1, 2, and 3 (see Figure 1 ) is also supportive for the nationwide representativeness of the current findings.

The use of TISPs and writing transcripts of all calls for comparison of the performance of different $\mathrm{OOH}$ centres is a costly and time consuming activity. Alternatively communication skills can be assessed using the RICE-communication list by listening to (recorded) telephone consultations with genuine patients. The thresholds for scores to be achieved by triagists have to be set by the management of each specific $\mathrm{OOH}$ centre. 


\subsection{Conclusion}

The results indicate how triagists, working at different $\mathrm{OOH}$ centres, communicated with patients by telephone and in addition suggest what is required to improve the quality of communication.

The ordering of the 17 items of the RICE-communication rating scale in three clusters and nine sub clusters provided a detailed insight into the quality of the communication skills of triagists:

- the results for cluster 1 (active listening) reveal that triagists asked for few details about the patients' personal situation or perception of the problem;

- the results for cluster 2 (active advising) demonstrate that care advice was usually given without checking whether the patient had understood and accepted the care advice;

- the results for cluster 3 (structuring the conversation) reveal that the skill of summarizing what has been said by the patient and the skill required to highlight different phases of the consultation were seldom utilised.

There was a significant positive correlation between the duration of the telephone consultation and the overall quality of the communication of $0.86(p<0.01)$.

\subsection{Practice implications}

Training of triagists should focus more on patient-centred communication with active listening, active advising and structuring the call. Apart from adequate communication skills, triagists need sufficient telephone consultation time to enable a high quality performance. 


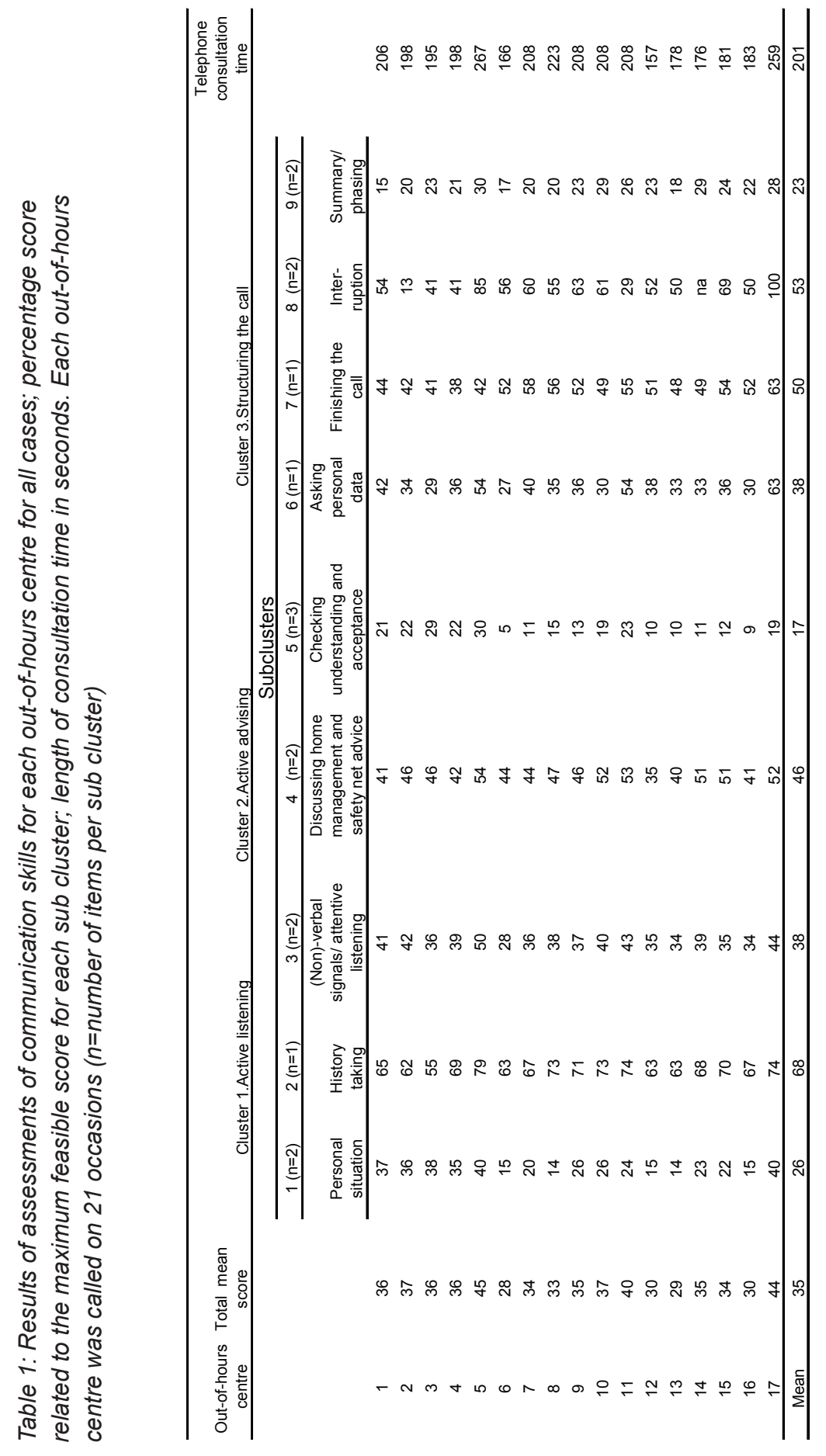


Figure 1. Boxplots (distributions) of variables mean percentage score for cluster 1, 2, and 3 vs. maximum feasible score. Per variable two panels are shown: the left panel presents the distribution for all calls $(N=357)$, the right panel the distributions per $\mathrm{OOH}$ centre (21 calls per boxplot). Each boxplot shows the mean value (solid line), the 25-th and 75-th percentiles (lower and higher boundaries of the grey box) indicating the central part, and the 10-th and the 90-th percentiles (grey "whiskers" outside the box) indicating the outer parts of the distribution
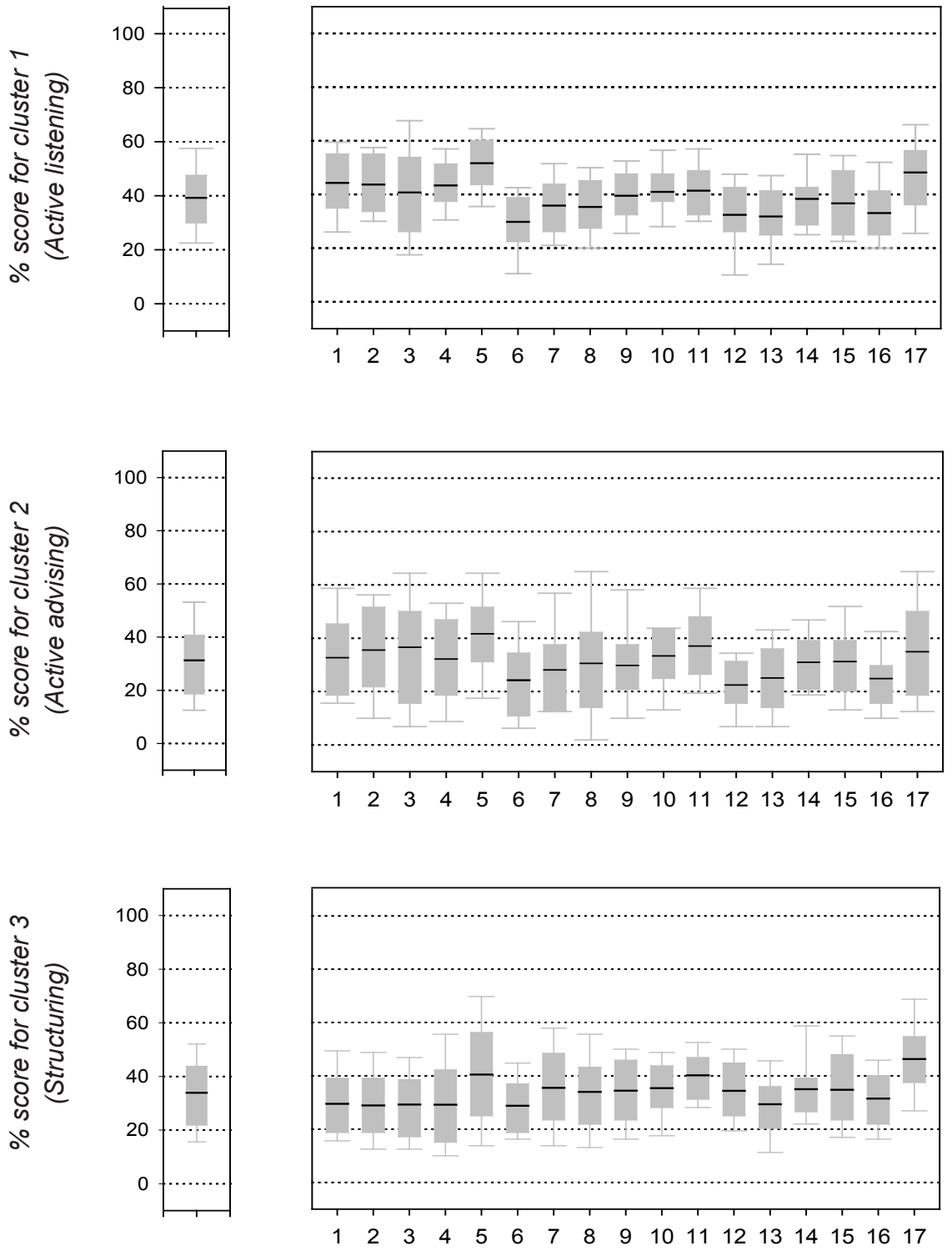

Out-of-hours centre 


\section{References}

1. Silverman J, Kurtz S, Draper J. Skills for communicating with patients. Oxford: Radcliffe Medical Press, 2000.

2. van den Brink-Muinen A, van Dulmen AM, Schellevis FG, Bensing JM. Second national study into diseases and actions in general practices. NIVEL 2004, Utrecht, the Netherlands.

3. Mead N, Bower P. Patient-centred consultations and outcomes in primary care: a review of the literature. Patient Educ Couns 2002 Sep;48(1):51-61.

4. Maguire P, Pitceathly C. Key communication skills and how to acquire them. Brit Med J 2002; 325;697-700.

5. Foster J, Jessopp L, Dale J. Concerns and confidence of general practitioners in providing telephone consultations. Br J Gen Pract 1999 Feb;49(439):111-3.

6. Moscato SR, David M, Valanis B, Gullion CM, Tanner C, Shapiro S, Izumi S, Mayo A. Tool development for measuring caller satisfaction and outcome with telephone advice nursing. Clin Nurs Res 2003 Aug;12(3):266-81.

7. Car J, Freeman G, Partridge M, Sheikh A. Improving quality and safety of telephone based delivery of care: teaching telephone consultation skills. Qual Saf Health Care 2004 Feb;13(1):2-3. Editorial.

8. Car J, Sheikh A. Telephone consultations. Brit Med J.2003;326:966-969 ( 3 May ).

9. Crouch R. An investigation onto effects of a computer based decision support program on Accident and Emergency nurses' assessment strategies in telephone consultation. Thesis 2000. University of Surrey.

10. Christensen MB, Olesen F. Out of hours service in Denmark: evaluation five years after reform. Brit Med J 1998 May 16;316(7143):1502-5.

11. Giesen P. Quality of out-of-hours care in the Netherlands. Thesis. UMC St Radboud Nijmegen 2007.

12. Payne F, Shipman C, Dale J. Patients' experiences of receiving telephone advice from a GP co-operative. Fam Pract 2001 Apr;18(2):156-60.

13. Wahlberg AC, Wredling R. Telephone nursing: calls and caller satisfaction. Int J Nurs Pract 1999 Sep;5(3):164-70.

14. Patel A, Dale J, Crouch R. Satisfaction with telephone advice from an accident and emergency department: identifying areas for service improvement. Qual Health Care 1997 Sep;6(3):140-5.

15. McKinley RK, Stevenson K, Adams S, Manku-Scott TK. Meeting patient expectations of care: the major determinant of satisfaction with out-of-hours primary medical care? Fam Pract 2002 Aug;19(4):333-8. 
16. Ram P, Grol R, Rethans JJ, Van der Vleuten C. Assessment of communicative and medical performance of general practitioners in daily practice. Validity, reliability and feasibility of video observation. Med Educ 1999;33:447-454.

17. Howie JG, Heaney DJ, Maxwell M. Measuring quality in general practice. Pilot study of a needs, process and outcome measure. Occas Pap R Coll Gen Pract 1997 Feb;(75) 1-32.

18. Maeseneer J. Consultation in general practice: a standard operating procedure? Patient Educ Couns 2004 Aug;54(2):227-33.

19. Rethans J-J, Gorter S, Bokken L, Morrison L. Unannounced standardized patients in real practice: a systematic literature review. Med Educ 2007 Jun;41(6):537-49.

20. Van der Vleuten C, Swanson D. Assessment of clinical skills with standardized patients: state of the art. Teaching and Learning in Medicine 1990;2:58-76.

21. Rethans JJ, Norcini JJ, Baron-Maldonado M, Blackmore D, Jolly BC, LaDuca T, Lew S, Page GG, Southgate LH. The relationship between competence and performance: implications for assessing practice performance. Med Educ 2002 Oct;36(10):901-9.

22. Maiburg BH, Rethans JJ, van Erk IM, Mathus-Vliegen LM, van Ree JW. Fielding incognito standardised patients as 'known' patients in a controlled trial in general practice. Med Educ 2004 Dec;38(12): 1229-35.

23. Derkx HP, Rethans J-J E, Knottnerus JA, Ram P. Assessing communication skills of clinical call handlers working at an out of hours centre. The development of the RICE rating scale. Br J Gen Pract 2007 May;57 (538):383-7.

24. Innes M, Skelton J, Greenfield S. A profile of communication in primary care physician telephone consultations: application of the Roter Interaction Analysis System. Br J Gen Pract 2006 May;56(526): 363- 8. 


\section{Chapter 6}

\section{Quod scripsi, scripsi¹.}

\section{The quality of the report of telephone consultations at Dutch out-of-hours centres}

H.Derkx (1)

JJ. Rethans (2)

Arno Muijtjens (3)

B.Maiburg (1)

R.Winkens (1)

Harrie van Rooij(4)

J.A.Knottnerus (1)

(1) Department of General Practice, Maastricht University, The Netherlands

(2) Skillslab, Maastricht University, The Netherlands

(3) Department Educational Development \& Research, Maastricht University, The Netherlands

(4) Department of Quality Management primary care out-of-hours centre Tilburg, the Netherlands

Submitted for publication

1 Gospel according St.John chapter 19 vs. 22; "What I have written, I have written". 


\section{Abstract}

\section{Objective}

To assess the quality of the content of reports of telephone consultations at out-of-hours centres and to investigate to what extent the reports reflect the actual telephone consultation.

\section{Design and Setting}

Cross sectional qualitative study; 17 out-of-hours centres in the Netherlands.

\section{Method}

Telephone Incognito Standardised Patients presented seven different clinical problems three times to 17 out-of-hours centres. All calls were recorded and transcribed. After the study the out-of-hours centres being called were asked for a copy of the report of the call. To assess the quality of the content of reports a focus group developed the RICE-report rating instrument. Two general practitioners assessed the quality of the content of the reports by using this instrument and compared its content with the transcripts.

\section{Results}

The out-of-hours centres returned a report for $78 \%$ of the 357 calls. For the remaining $22 \%$ of the calls no report was written. Reports contained almost always information about the medical reason for calling but little information about details of the clinical history. Patients' expectation, personal situation or perception of the care advice was seldom documented.

In all but one out-of-hours centre answers to obligatory questions were reported by triagists although they had not been asked, varying between $1 \%$ and $54 \%$ of all questions entered. Triagists entered a subjective evaluation of a patients' condition in $12 \%$ of the reports.

\section{Conclusion}

The reports contained almost always information on the clinical problem and the care advice given. Reports of telephone consultations of out-of-hours centres contained little information on patients' clinical and personal condition. This could potentially endanger patients' continuity of care and might pose legal consequences for the triagist. 


\section{Introduction}

After a telephone consultation at an out-of-hours centre the call handler writes a medical report to record what has been discussed with the caller. The call handler is the person who actually handles the request for medical advice and is called triagist.

The report of a telephone consultation serves different purposes. Firstly it is important to secure continuity of care. The report is the only documented and therefore quickly accessible source of information about the content of a call. Studies show that between 35 and 50 $\%$ of all clinical problems presented by telephone are dealt with by advising self care $(1,2)$. These calls might be audio recorded but if the patient calls back, the report informs the triagist quickly about the latest telephone contact. Secondly the report can be used for medicolegal purposes if a patient has made a complaint about the care provided $(3,4)$. Thirdly reports can be used for epidemiological research but the reliability of the symptom or diagnostic orientated codes is limited as little information is available on the accuracy of the coding process $(5,6)$.

In spite of the importance of medical records no research on reports of telephone consultations with triagists at out-of-hours $(\mathrm{OOH})$ centres could be identified. The first objective of our study was to investigate the quality of the content of information in these reports. Research with simulated patients visiting a general practitioner (GP) revealed a low correlation between what had been recorded and what had been asked (7). Accordingly, the second objective of our study was to investigate to what extent the reports at out-of-hours centres reflected the content of the telephone consultations.

\section{Methods}

Cases, protocols and rating instrument

A focus group was asked to develop an instrument to assess the quality of clinical reports of telephone consultations at an $\mathrm{OOH}$ centre. The group consisted of individuals representing the four stakeholders involved in telephone calls to an $\mathrm{OOH}$-centre: the patient, the call handler, the general practitioner and the management team. Each party was represented by two members with experience in working at or dealing with an $\mathrm{OOH}$-centre. They developed the RICE-report instrument (the acronym RICE stand for Reason for calling, Information gathered, Care advice given, Evaluation of the care advice with the patient). This instrument contains patient and case specific items to be reported (see Appendix A describing the full content of the RICE-report instrument).

The research team developed protocols with obligatory questions to be asked for clinical symptoms that are known to be presented 
frequently on the telephone to $\mathrm{OOH}$ centres: a 5 year old child with a fever, an adult with nose bleeding, an adult with fever and a 5 year old child with vomiting (8-10). A team of GPs validated the protocols and reached consensus on the obligatory questions to be asked for each of these symptoms. The case specific part of the RICE-report instrument contains the suggested obligatory questions and the care advice required. The patient specific part contains the following items: clinical problem; expectation (wants advice or to be seen by a doctor); personal situation (being worried, anxious) and patients' evaluation of the care advice (accepting or rejecting the advice).

\section{Calls and reports}

In October 2004 there were $105 \mathrm{OOH}$ centres operative in the Netherlands. All $\mathrm{OOH}$ centres were asked for permission to be selected for the research study. Of the 98 centres that gave permission 17 were selected to be called. We performed a balanced selection where for each of the 12 provinces of the Netherlands the size of the population in that province determined the number of $\mathrm{OOH}$ centres to be selected. The centers per province were then selected at random.

The selected symptoms were presented in seven different scenarios by a team of specially trained Telephone Incognito Standardised Patients (TISPs). Each case was presented three times to each selected $\mathrm{OOH}$ centre, therefore 21 calls were made to each $\mathrm{OOH}$ centre. All calls were recorded and transcribed for further assessment.

After the study the $17 \mathrm{OOH}$ centres being called were asked to send a copy of the reports of these telephone consultations.

\section{Variables and statistical analysis}

The quality of the reports was assessed with the RICE-report instrument by two GPs independently. They could enter the score: "Yes (reported)" or "No (not reported)".

For each $\mathrm{OOH}$ centre the following variables were calculated as indicators of quality:

- percentage of reports returned;

- percentage of reported patients' clinical problem;

- percentage of reported patients' expectation;

- percentage of reported patients' personal situation ;

- percentage of reported obligatory questions asked;

- percentage of reported care advice given;

- percentage of reported patients' evaluation of the advice. 
To investigate to what extent the report reflected the actual telephone consultation a comparison was made between the clinical content of the reports and the transcripts. We calculated:

- percentage of all obligatory questions absent in the report but present in the transcript (not reported but asked);

- percentage of all obligatory questions present in the report but absent in the transcript (reported but unasked).

For each of these variables the average percentage of the two raters were used for further analysis per report for all $\mathrm{OOH}$ centres.

Descriptive statistics and results of the analysis of variance were obtained by using the statistical software package SPSS version 15.

\section{Results}

The TISPs made 357 calls and 280 copies of the reports were returned. The percentage of returned reports of 21 calls made to each $\mathrm{OOH}$ centre varied from $23 \%$ to $100 \%$ per $\mathrm{OOH}$ centre (table 1). At $16 \mathrm{OOH}$ centres the triagists had not documented all calls.

The mean percentage score for the reported four different aspects of the RICE-report instrument are:

- Reason for calling:

o clinical problem: $99 \%$, varying from $83 \%$ to $100 \%$,

o patients' expectation: $52 \%$, range $17 \%$ to $80 \%$,

o patients' personal situation: $15 \%$, this varied from zero to $49 \%$;

- Information gathered: obligatory clinical questions compared with the agreed standard was $20 \%$. This varied from $12 \%$ to $34 \%$;

- $\quad$ Care advice given: $98 \%$, range $83 \%$ to $100 \%$;

- Evaluation of the advice by the patient: $11 \%$, varying from zero to $63 \%$.

Comparison of the report with the transcript revealed a mean percentage of $19 \%$ for obligatory questions asked but not reported, which varied from $8 \%$ to $29 \%$. The mean percentage of obligatory questions reported but not asked was $10 \%$, rang zero to $54 \%$ (table 2). 


\section{Discussion}

\section{Summary of findings}

Triagists made a report for $78 \%$ of all calls. For the remaining $22 \%$ of the calls no report was written. Reports contained information on the medical reason for calling in most cases but little information on previous medical history. Patients' expectation or personal situation were seldom documented. Patients' evaluation of the care advice was mentioned regularly at two out-of-hours centres, at the others not at all. In all but two out-of-hours centers triagists had entered more obligatory questions than they asked.

\section{Strengths and limitations of this study}

We took a sample of 17 out of the $98 \mathrm{OOH}$ centres which had given permission to be called. Even though there are minor organisational differences between Dutch $\mathrm{OOH}$ centres basically they work in the same way (11). The relatively small variation over the $\mathrm{OOH}$ centres of the quality of the reports is also supportive for the nationwide representativeness of the current findings.

We used TISPs and a transcript was made of all calls which are costly and time consuming activities. The content of a report can also be assessed with the RICE-report instrument and compared with the content of the call by listening to (recorded) calls with genuine patients.

In the Netherlands one of the GPs on call at the $\mathrm{OOH}$ centre is responsible for all decisions made by the triagists. In cases where the triagist has decided to give self care advice, the approval of this decision by the GP in charge will be based mainly on the report. If needed, the GP can ask the triagist for additional information. Therefore we were surprised that only at one $\mathrm{OOH}$ centre a report of all 21 calls had been made and at another $\mathrm{OOH}$ centre a report had been written for only $23 \%$ of all calls. It is known that some GPs do not document all face-to-face consultations (7), but we do not know why some triagists did not document all telephone consultations. We also do not know whether they realize that this omission might have clinical consequences for the patient and legal consequences for the organisation, and also for the triagist.

The number of obligatory questions reported compared with the agreed standard, was very low at all $\mathrm{OOH}$ centres indicating that there was minimal documented information on the clinical condition of the patient. Comparison of the transcripts with the reports revealed two explanations for this low score. Firstly those questions had not been asked. Secondly when they had been asked and had been 
answered with a "No", they were often not documented. This means that mainly positive findings were reported but negative findings were not reported as frequently. We do not know whether GPs on call discussed calls with the triagists before they validated the triagists' decisions without entering this additional information into the report.

The assessors of the reports noted that triagist often wrote; "No alarming signals" or "No other complaints". They extended their investigation and retrieved these remarks in $12 \%$ of all reports. However, by comparing the transcripts with the reports they could not identify which questions were asked to support those remarks. Therefore we conclude that for these calls the triagist had reported a subjective evaluation of patients' condition.

We were surprised with the finding that unasked obligatory questions were sometimes entered into the reports. This might endanger the health of the patient as it might mislead the GP evaluating the quality of care provided over the telephone and it might also have serious legal consequences. Discussion of these findings with the managers of the four $\mathrm{OOH}$ centres where this had happened frequently revealed that they used a computerized system which generated a part of the reports automatically. They all decided to take immediate action to solve this problem.

\section{Conclusion}

The assessments of the quality of the content of the reports revealed that the reports contained almost always information on the clinical problem and the care advice given. Not always a report of telephone consultations was made at all $\mathrm{OOH}$ centres. The reports contained little patient and case specific information. Accordingly, these reports can not contribute much to secure continuity of the care provided.

Comparison of the reports with the transcripts revealed that in some reports obligatory questions had been entered which had not been asked, or a subjective evaluation of the patients' condition had been presented. This might endanger the health of the patient and pose a medicolegal risk to the triagist and the $\mathrm{OOH}$ centres organisation.

\section{Further research}

The reports were mainly hand typed by the triagists what will have been a time consuming activity. Research is needed to investigate instruments to support triagists in generating reports automatically and meeting medical and legal standards. 


\section{Acknowledgements}

We thank the managers of the 17 out-of-hours centres involved in this study for their cooperation by sending the reports.

Ethical approval: Under Dutch law no ethical approval is needed to phone or to record calls made by a standardised patient to an out-ofhours centre once permission has been given by the management of the $\mathrm{OOH}$ centre.

\section{Funding body}

The research was funded by CZ and VGZ, both Health Insurance Companies in the Netherlands.

\section{Competing interests}

The authors' work was independent of the funders. 


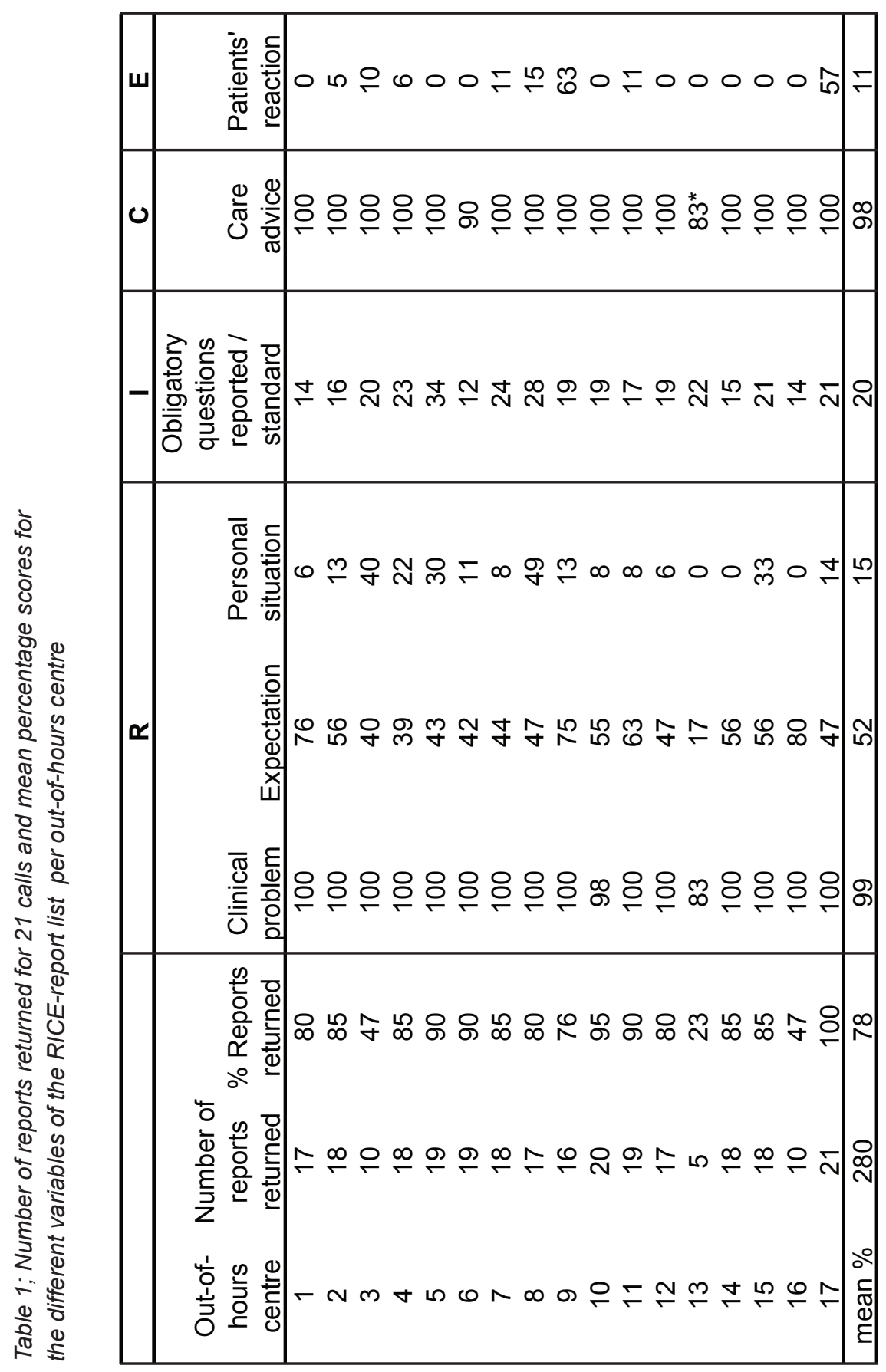


Table 2; Number of reports returned for 21 calls and percentage obligatory questions asked compared with reported per out-of-hours centre

\begin{tabular}{|cccc|}
\hline $\begin{array}{c}\text { OOH } \\
\text { centre }\end{array}$ & $\begin{array}{c}\text { Number of reports } \\
\text { returned }\end{array}$ & $\begin{array}{c}\text { Obligatory questions } \\
\text { not reported / indeed } \\
\text { asked }\end{array}$ & $\begin{array}{c}\text { Obligatory questions } \\
\text { reported / but not } \\
\text { asked }\end{array}$ \\
\hline 1 & 17 & 22 & 24 \\
2 & 18 & 19 & 17 \\
3 & 10 & 19 & 13 \\
4 & 18 & 19 & 8 \\
5 & 19 & 11 & 54 \\
6 & 19 & 25 & 8 \\
7 & 18 & 22 & 4 \\
8 & 17 & 12 & 4 \\
9 & 16 & 29 & 6 \\
10 & 20 & 26 & 6 \\
11 & 19 & 26 & 8 \\
12 & 17 & 19 & 2 \\
13 & 5 & 17 & 4 \\
14 & 18 & 8 & 6 \\
15 & 18 & 18 & 4 \\
16 & 10 & 17 & 0 \\
17 & 21 & 16 & 10 \\
\hline mean $\%$ & 280 & 19 & \\
\hline
\end{tabular}




\section{References}

1. Crouch R. An investigation into the effects of a computer based decision support program on Accident and Emergency nurses' assessment strategies in telephone consultation. 2000 Thesis. University of Surrey.

2. Lattimer V, George S, Thompson F, Thomas E, Mullee M, Turnbull J, Smith $\mathrm{H}$, Moore M, Bond $\mathrm{H}$, Glasper A. Safety and effectiveness of nurse telephone consultation in out of hours primary care: randomised controlled trial. The South Wiltshire Out of Hours Project (SWOOP) Group. BMJ 1998 Oct 17;317(7165):1054-9.

3. Röhlig HW. Documentation in law and general practice. Zentralbl Chir 1999;124 suppl 1:49-51.

4. Roberts RG. Seven Reasons Family Doctors Get Sued and How to Reduce Your Risk. Fam Pract Manag 2003 Mar;10(3):29-34.

5. Giesen P. Quality of out-of-hours care in the Netherlands. Thesis. UMC St Radboud Nijmegen 2007.

6. Spies TH, Mokkink HG, De Vries Robbé PF, Grol RP. Which data source in clinical performance assessment? A pilot study comparing self-recording with patient records and observation. Int J Qual Health Care 2004 Feb;16(1):65-72.

7. Rethans J-J, Martin E, Metsemakers J. To what extent do clinical notes by general practitioners reflect actual medical performance? A study using simulated patients. BJGP1994;44:153-156.

8. Post J. Large scale primary care service during after-hours (Grootschalige huisartsenzorg buiten kantooruren). Thesis, University of Groningen, The Netherlands, Groningen 2004 .

9. Dale J, Williams S, Crouch R, Patel A. A study of out-of-hours telephone advice from an A\&E department. Br J Nurs 1997 Feb 1326;6(3):171-4.

10. Crouch R, Patel A, Williams S, Dale J. An analysis of telephone calls to an inner-city accident and emergency department. J R Soc Med 1996 Jun;89(6):324-8.

11. Inspectie voor de Volksgezondheid. Huisartsenposten vertonen nog veel kinderziekten. Den Haag 6 mei 2004 (Dutch Health Care Inspectorate "Out of hours centres in the Netherlands show teething problems" The Hague, 2004). 


\section{Appendix A}

\section{RICE-report instrument}

To assess the quality of the information in a report of a telephone consultation with an out-of-hours centre.

The characters of RICE stand for; $\underline{R}$ eason for calling (patient specific), Information gathered (case specific), $\underline{\text { Care advice (the }}$ outcome of the triage; case specific), Evvaluation (patients' reaction to the advice).

\section{Clinical problem:}

Score; Yes $=1:$ present; No $=0$ : not present

Reason for calling (patient specific)

$\underline{\text { Report }}$

1. Clinical problem

2. Patients' expectation

3. Patients' personal situation (anxious, worried)

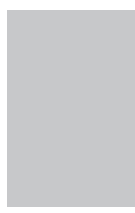

Obligatory questions asked (case specific) 4.

Care advice (Outcome) (case specific)

5. Self care

6. Consultation at the out-of-hours centre

7. To visit general practitioner in office hours

8. Call back

9. Other

Evaluation: (patient specific) 10. Patients' reaction and evaluation 
Chapter 7

General discussion 


\section{Introduction}

This thesis describes the investigation of the quality of telephone triage at out-of-hours centres in the Netherlands.

The process in which both the urgency and the care required for telephone calls is determined, is called telephone triage. It is not a new phenomenon. General practitioners have provided primary care service out-of-hours since the telephone was invented (1). What is new is the increased scale of such services in many countries. The provision of primary care during out-of-hours has changed from small rotas where a general practitioner or his partner answered the calls of patients at home, into large groups of general practitioners who work together with nurses or healthcare assistants at an out-of-hours centre (2-3). At these centres call handlers answer all incoming calls. They are called triagists as they perform telephone triage. They do this without seeing the patient (4), which presents significant differences in comparison to a face-to-face triage contact.

To assess the quality of telephone triage the care process of telephone triage was analyzed. Three phases were identified. In the first phase questions are asked about patients' condition and personal situation. In the second phase, by evaluating the information gathered, the required care is determined and discussed with the patient. In the third phase a clinical report is written about what has been discussed with the patient. To perform high quality telephone triage clinical knowledge and good communication skills are required. One needs also recording-skills as a report needs to be written that meets medical and legal requirements.

In this chapter the main findings of our investigations and conclusions are summarized. Subsequently the methodological strengths and weaknesses of this study are discussed. After some reflections on aspects of modern communication, safety in health care and the support required for telephone triage recommendations for improvement of the quality of telephone triage at out-of-hours centres and suggestions for further research are presented. 


\section{Main findings}

To study the quality of telephone triage at out-of-hours centres Telephone Incognito Standardised Patients (TISPs) made 357 calls to out-of-hours centres for different medical problems (Chapter 2). Assessment of the accuracy of role playing was found to be close to $100 \%$ and none of the out-of-hours centres being called detected that they had been called by a TISP.

To develop an instrument to assess the quality of telephone communication at out-of-hours centres a focus group composed a list of 17 items (5) (chapter 3). The list was validated by experts on communication. The internal consistency (Cronbach's alpha) was 0.73 . This instrument is called the RICE-communication rating list. The characters of the acronym RICE indicate the four consecutive phases of a (telephone) consultation. Phase one "Reason for calling"; phase two "Information gathered"; phase three "Ćare advice given" and phase four "Evvaluation of the call with the patient".

To assess the quality of clinical case handling and communication seven clinical cases and scenarios were developed for the TISPs to present. A panel of general practitioners set the standard for each of the seven cases by listing obligatory questions to be asked, the desirable content of the home management and safety net advice and the outcome of the triage. Out of 98 out-of-hours centres which had given permission to be called 17 centres were selected. They were spread over the country and the number of selected out-ofhours centres per province was balanced against its population (6).

A total of 357 calls were scheduled but the TISPs had to make 375 calls as 18 calls had not been self-recorded correctly.

The assessments of the quality of clinical case handling (Chapter 4) demonstrated that:

- triagists asked few questions about the clinical condition of the patient before determining the urgency level;

- answers to questions about the clinical condition were not always correctly evaluated clinically, either by triagists or by general practitioners who had made a return call to the TISP;

- the content of home management and safety net advice was limited;

- the suggested standard for the outcome of the triage was achieved in $58 \%$ of all calls;

- the required outcome was underestimated in $41 \%$ of all calls and in $1 \%$ it was overestimated.

To assess the quality of communication the RICE-communication rating list was used (chapter 5) and the correlation between the quality of communication and the telephone consultation time was determined (7). 
To evaluate the results the 17 items of this instrument were divided over three clusters. Each cluster describes a general basic skill of communication. Cluster 1 deals with active listening, cluster 2 with active advising and cluster 3 with structuring the telephone consultation.

The results for these three clusters were:

- cluster 1: triagists asked questions about the clinical aspects of the problem correctly on most occasions but little about a patients' personal situation or perception of the problem;

- cluster 2: advice was usually given without checking with the patients for their understanding or acceptance of the advice;

- cluster 3: calls were often handled in an unstructured way, without summarizing or clarifying the different steps within the consultation.

There was a significant positive correlation between length of consultation and quality of communication of $0.86(p<0.01)$.

To assess the quality of the reports of the calls the focus group which composed the RICE-communication list developed the RICE-report list (chapter 6). The meaning of the acronym RICE is as mentioned above. After the TISPs had completed all calls the 17 out-ofhours centres were asked for a copy of the reports. All 17 centres cooperated by sending the available reports.

In $22 \%$ of the calls no report was written at all. Reports usually contained information about the medical reason for calling but little information about previous medical history. Patients' expectation or personal situation was often not documented. Patients' own evaluation of the care advice was mentioned regularly at only two out-of-hours centres. At some out-of-hours centres triagists had entered more obligatory questions than they had asked into the report or had made a subjective evaluation of patients' condition. 


\section{Methodological considerations}

For this research project Telephone Incognito Standardised Patients (TISPs) were used to assess and to compare the performance of telephone triage at different out-of-hours centres. We used this methodology while by assessing calls with genuine nonstandardised patients another design of study is needed to compare the performance of triagists. As we had little experience of working with TISPs only cases that would require urgent or self care were presented. No case should have required immediate care or transport by an ambulance. It is known that triagists handle immediate or high urgency cases very accurately (8) but as such cases were excluded from our research, we do not know how the triagists of the selected out-of-hours centres would have handled such cases and what the influence of those results would have been on the total score of clinical case handling.

We chose a balanced sample of 17 out-of-hours centres that had given permission to be involved, out of a total possible 98 centres. Although the results at other centres might have been different we consider our findings representative for out-of-hours centres in the Netherlands.

The internal consistency of the RICE-communication rating list was determined directly after the focus group had composed the list. Therefore six calls were assessed by 10 raters. The internal consistency was then 0.73 (Cronbach's alpha). The raters made suggestions to improve the description of the usage of the 17 items of the list. At a later stage of this study another group of eight raters were trained. They received the same tape recorded calls to assess. The Cronbach's alpha was then 0.89. The difference in internal consistency might be due to better training and an improved manual to work with.

One of the objectives of this study was to investigate the quality of clinical case handling as performed by triagists. We did not investigate whether a triagist had used a decision support system, such as a computer based system or a handbook. A different study design would be required to compare the results achieved by using different systems.

Each call was transcribed and all calls were assessed for each aspect of quality by two assessors independently. Transcribing is costly and to make double assessments is time consuming. Quality assessment for individual triagists could be made without a transcript by scoring recorded calls with non-standardised genuine patients using standards as set out in our study. This means assessment of the appropriateness of the outcome, history taking and content of home management and safety net advice. 
The RICE-communication and the RICE-report rating instrument can be used to assess almost any clinical case or report. With these instruments recorded calls with genuine patients including the matching reports, can be assessed for quality without a transcript, provided the criteria for the selection of these cases are met (the criteria are described in the manual of the RICE-communication list).

The RICE-instruments have been accepted by the Vereniging Huisartsenposten Nederland (VHN: Dutch Organisation of Out-ofHours Centres) as assessment tools for certification of triagists. However, the scoring thresholds to be achieved for certification for the aspects of quality described have not been set yet.

\section{Conclusions}

Analysing the care process during telephone triage proved to be an useful way to formulate the specific aspects requiring investigation for overall quality assessment.

Using Telephone Incognito Standardised Patients proved to be a valid and feasible method. They successfully self-recorded nearly all calls. The assessments of their performance demonstrated that they played their role very accurately. We concluded that the 17 out-ofhours centres in this study have been called in a consistent fashion by the TISPs.

The quality of communication was scored with the RICE-communication list. The results for the general skills (the skill of active listening, active advising and structuring a call) revealed some shortcomings in communication by triagists. This knowledge could be used to assist in the training of triagists to help them with modern day requirements for patient-centred communication.

The significant positive correlation between duration of telephone consultation and the quality of communication indicates that apart from adequate communication skills, triagists need sufficient time for telephone consultation to enable high quality performance.

The design of the cases presented, demonstrated the importance of thorough history taking and clinically correct evaluation of the answers. This is specifically required where a triagist considers giving home care advice. The overall results reveal that health risks to patients were not sufficiently minimised.

Triagists did not make a report for all calls and reports were not informative or always reliable regarding a patients' clinical condition. We concluded that the reports contributed little to ensure continuity of care. 


\section{Reflections}

This chapter reflects on modern communication, safety in health care and telephone triage at out-of-hours centres.

\section{Communication}

Communication between doctors and patients has changed during the past few decades due to social shifts in our society. In the past communication focussed on the disease concerned, whereas doctors now need to communicate with their patients in a patientcentred way $(9,10)$. The central point of a consultation is the patient who feels ill, rather than the illness. The need for high quality patientcentred communication skills in telephone triage is also recognised (11-15). Several studies have demonstrated high patient satisfaction with primary care service carried out by out-of-hours centres (1620). Satisfaction is often related to the triagist being able to provide reassurance and the fact that the caller feels that they have received adequate time to express their concerns (21-23). Patients' dissatisfaction with telephone consultation is often due to the lack of acknowledgement of physical or emotional needs or not meeting patients' expectations $(24,25)$. Although satisfaction with this service is relevant it does not give an objective view of the overall safety of such a service (26).

\section{Safety}

Safety and quality of telephone triage have often been discussed and investigated. In 2006 the Dutch Health Care Inspectorate concluded that the organisation of out-of-hours services had improved considerably since their start but questioned the safety of telephone triage $(27,28)$.

The quality of the care advice by telephone has often been determined by assessing the outcome of telephone triage but the results of these assessments can not be conclusive regarding the safety of triage $(21,29-37)$.

Safety in health care involves preventing unintended harm to patients. Since the report "To err is human" was published in 1999 (38) there is increasing interest in the prevention of errors in health care. In the Netherlands this report resulted in the Veiligheids Management Systeem (Safety Management System) with recommendations to prevent errors in the health system (39). The report strongly advises the development and adaptation of standards for patients' safety and to create a "culture of safety" in health organisations. This culture of safety will influence training of care providers. It also requires instruments to improve the safety of the patient and enable care providers to avoid reliance on subjective knowledge and recall. 
The petrochemical and aviation industries have demonstrated the importance of investment in preventing errors for many decades $(40,41)$. To decrease risks they analyze the processes involved, then they look for possible errors and risks in each step of a process to find solutions to prevent the mistakes (42). In the same way analyzing the care process during telephone triage can identify possible errors and risks. Once identified, actions to be taken to minimize such errors can be studied.

\section{Telephone triage}

One of the reasons for the poor performance in the three investigated aspects of quality might be that out-of-hours centres and telephone triage is a new phenomenon in the Netherlands where out-of-hours primary care service has developed rapidly, perhaps too rapidly. Most Dutch out-of-hours centres began to operate from 1998 onwards with little experience in this field (43). From the start healthcare assistants are assigned to handle all incoming calls at the out-of-hours centre. They lack the medical education and the clinical experience of a general practitioner. Yet, they stand in the frontline and bear the heavy burden of responsibility for telephone triage. Have they been trained adequately for this enormous responsibility $(29,32,44-46)$ and have they been supplied with all required tools to perform high quality telephone triage (47)?

To support clinical case handling triagists can use a protocol guideline book (48) or computer based decision supporting system. However, the guideline book is frequently not used (49) and to what extent other systems are used, is unknown. More training might improve the safety of telephone triage but the kind of training needed to determine appropriate clinical urgency is unknown. How can personnel be trained in telephone triage for complicated clinical situations that occur within an ageing population and new developments in clinical knowledge? It has been suggested that only general practitioners should perform telephone triage but there is no indication that they perform better than triagists (50). This study identified misinterpretation of clinical information from TISPs by triagists and general practitioners on a few occasions (Chapter 4).

Studies of the process of decision making by nurses have revealed that they may find it difficult to consider possible causes for some clinical problems other than those immediately brought to mind (51). For high-urgency situations they often apply heuristic rules based on symptoms. For moderate to low-urgency conditions they often exploit contextual knowledge of the situations to identify the needs of the patients and to negotiate the best plan of action to meet these needs (52-54). Little is known about the decision making process 
used by Dutch triagists. Research findings on their decision making process might need to be taken into account in designing supporting tools which fit with their knowledge and needs.

\section{Recommendations}

Evaluation of the results of quality of communication in this study revealed that triagists communicated with patients in a diseasecentred way. We recommend that triagists be trained to communicate in a patient-centred way, applying the general skills of active listening, active advising and structuring a telephone consultation.

Safety of clinical case handling, good communication, reliable documentation, are all related to the delivery of high quality care using the telephone. There is a need to incorporate a philosophy regarding patient safety among everyone involved in primary care service provided by out-of-hours centres. The different stakeholders within this service, such as triagists, general practitioners, health insurance companies, members of the management team, the Health Care Inspectorate, organisations representing patients, should all work hard to provide high quality of care. Before successful strategies for improvement in the quality of care provided by out-of-hours centres can be developed the individual needs and opinions of all its stakeholders need to be identified (55).

The need for a joint effort to improve quality of telephone triage is well described in the following (partly adapted) conclusion in the report "To err is human" (38): "The majority of medical errors do not result from individual recklessness. More commonly, errors are caused by faulty systems or processes that lead people to make mistakes or fail to prevent them. Mistakes and insufficient quality (in telephone triage) can be prevented by designing (the out-of-hours organisation) at all levels to make it safer and to make it harder for people to do something wrong and easier for them to do it right. Of course, this does not mean that individual care providers (of an outof-hours centre) can be careless. They still must be vigilant and held responsible for their actions. But when an error occurs, blaming an individual does little to make the system safer and prevent someone else from committing the same error."

The ageing of the population, the increase of patients with chronic diseases, the increase in demands for medical care at any moment of the day or night, the complexity of many clinical cases, more and more people travelling to all corners of the world and bringing back unfamiliar diseases, all these aspects will challenge the quality of telephone triage in the near future, but how to cope with these challenges and how to improve aspects of safety? 
Research has demonstrated that a high quality of telephone triage outcomes can be achieved using computer based clinical decision supporting systems (56-58). These systems are used in many countries to support triagists but little is known about their ideal design and content. The shortcomings in the quality of clinical case handling as revealed in this study indicate some possible requirements for computerised decision support systems. A minimum requirement would be for question prompts to appear relevant to any clinical symptom that may present and also recommendations for the urgency outcome of triage based on answers given. In addition relevant home management and safety net advice should be made available. These systems can also be used to support the documentation of the call although accuracy would still depend to a great extent on user input.

\section{Further research}

The results of the assessment of role-playing by the TISPs demonstrated the validity and reliability of this method. Each out-ofhours centre was approached in a consistent manner. This method of working with TISPs can be used to train and assess triagists, general practitioners and trainees. Any type of clinical problem can be presented by TISPs, but preparation and training to make calls for highly urgent cases still needs to be studied.

The RICE-communication list was the first edition of a rating list, therefore we are advising that each item is re-evaluated for its validity after (for example) a period of 5 years. This is needed as the practical usage of this instrument at out-of-hours centres may reveal new insights.

To meet contemporary demands for consultation triagists need to be trained in patient-centred communication. The effectiveness of the method to train triagists in the general skills of active listening, active advising and structuring need to be investigated.

Little is known about patient's experiences regarding telephone communication with triagists. Although patients were present in the focus group which developed the assessment tool for communication, patient opinions on this subject still need to be investigated to identify shortcomings in training and performance of triagists from their point of view.

The duration of telephone consultation was positively correlated with the quality of communication for our calls, which involved only uncomplicated cases. The duration of a call depends on the communication skills of the triagist as well as the nature of the 
problem presented. Accordingly, research is needed to determine acceptable limits for the duration of calls while at the same time enabling effective and high quality communication.

To improve the quality of telephone triage in 2006 the Vereniging Huisartsenposten Nederland (VHN: Dutch Organisation of Outof-Hours centres) initiated a program to certificate triagists. This certification implies a competence test on clinical knowledge and a performance test in communications skills and, in the near future, as well as the documentation of calls. For this certification the RICEcommunication and the RICE-report list are assigned to be used as assessment tools. Medical knowledge of physicians can predict actual clinical performance under exam circumstances but to what extent such tests are predictive for performance of triagists who are not physicians, needs to be investigated $(59,60)$.

In the Netherlands a few out-of-hours centres use a computer based clinical decision support system. The implementation of these systems at other out-of-hours centres means a change in clinical practice for everybody involved in telephone triage. Therefore, it is advisable that beforehand the obstacles to this change are identified to obtain maximum benefit from these systems for patients and triagists. The experience with safety procedures as applied in oil and gas industry or aviation might be instructive for a safe use of these systems at out-of-hours centres (61).

Self triage by patients as part of on-line health and disease management programmes (E-health) and the application of telemedicine prove to become important tools in the provision of medical care (62-64). However, research is needed to explore its safety, feasibility, and acceptability to predict the risks and benefits of these modern health care applications (65).

We hope that this thesis will contribute to a patient-centred careby-phone with maximal quality and safety, minimal health risk to the patient and optimal communication between triagist and patient. 


\section{References}

1. $\mathrm{S}$ H Aronson. The Lancet on the telephone 1876-1975. Med Hist 1977 January; 21(1): 69-87.

2. Grol R, Giesen P, van Uden C. After-hours care in the United kingdom, Denmark, and the Netherlands: new models. Health Aff (Millwood) 2006 Nov-Dec;25(6):1733-7.

3. Post J. Large scale primary care service during after-hours (Grootschalige huisartsenzorg buiten kantooruren). Thesis, University of Groningen, The Netherlands, Groningen 2004 .

4. Crouch R, Patel A, Williams S, Dale J. An analysis of telephone calls to an inner-city accident and emergency department. J R Soc Med. 1996 Jun;89(6):324-8.

5. Derkx HP, Rethans J-J E, Knottnerus JA, Ram P. Assessing communication skills of clinical call handlers working at an out of hours centre. The development of the RICE rating scale. Br J Gen Pract 2007 May;57 (538):383-7.

6. Dutch Health Care Inspectorate. Out of Hours Centres in the Netherlands (Huisartsenposten in Nederland: Rapport Inspectie voor de Volksgezondheid). The Hague, april 2004.

7. Ram P, Grol R , Rethans JJ, Van der Vleuten C. Assessment of communicative and medical performance of general practitioners in daily practice. Validity, reliability and feasibility of video observation. Med Educ 1999;33:447-454.

8. Leprohon J, Patel VL. Decision-making strategies for telephone triage in emergency medical services. Med Decis Making 1995 Jul-Sep;15(3):240-53.

9. van den Brink-Muinen A, van Dulmen AM, Schellevis FG, Bensing JM. Second national study into diseases and actions in general practices. NIVEL 2004, Utrecht, the Netherlands.

10. Mead N, Bower P.Patient-centred consultations and outcomes in primary care: a review of the literature. Patient Educ Couns 2002 Sep;48(1):51-61.

11. Silverman J, Kurtz S, Draper J. Skills for communicating with patients. Oxford: Radcliffe Medical Press, 2000.

12. Foster J, Jessopp L, Dale J. Concerns and confidence of general practitioners in providing telephone consultations. Br J Gen Pract 1999 Feb;49(439):111-3.

13. Moscato SR, David M, Valanis B, Gullion CM, Tanner C, Shapiro S, Izumi S, Mayo A.Tool development for measuring caller satisfaction and outcome with telephone advice nursing. Clin Nurs Res 2003 Aug;12(3):266-81.

14. Car J, Freeman G, Partridge M, Sheikh A. Improving quality and safety of telephone based delivery of care: teaching telephone consultation 
skills. Qual Saf Health Care 2004 Feb;13(1):2-3. Editorial.

15. Car J, Sheikh A. Telephone consultations. BMJ 2003;326:966-969 (3 May).

16. Chang BL, Mayo A, Omery A. Consumer satisfaction with telehealth advice-nursing. Medinfo. 2001;10(Pt 2):1435-9.

17. Moll van Charante E, Giesen P, Mokkink H, Oort F, Grol R, Klazinga $\mathrm{N}$, Bindels P. Patient satisfaction with large-scale out-of-hours primary health care in The Netherlands: development of a postal questionnaire. Fam Pract 2006 Aug;23(4):437-43.

18. Omery A. Advice nursing practice: on the quality of the evidence. J Nurs Adm 2003 Jun;33(6):353-60.

19. Wahlberg AC. Telephone advice nursing. 2004 Department of nursing Sweden. Thesis.

20. Lee TJ, Guzy J, Johnson D, Woo H, Baraff LJ. Caller satisfaction with after-hours telephone advice: nurse advice service versus on-call pediatricians. Pediatrics 2002 Nov;110(5):865-72.

21. Giesen P. Quality of out-of-hours care in the Netherlands. Thesis. UMC St Radboud Nijmegen 2007.

22. Payne F, Shipman C, Dale J. Patients' experiences of receiving telephone advice from a GP co-operative. Fam Pract 2001 Apr;18(2): 156-60.

23. Wahlberg AC, Wredling R. Telephone nursing: calls and caller satisfaction. Int J Nurs Pract 1999 Sep;5(3):164-70.

24. Patel A, Dale J, Crouch R. Satisfaction with telephone advice from an accident and emergency department: identifying areas for service improvement. Qual Health Care 1997 Sep;6(3):140-5.

25. McKinley RK, Stevenson K, Adams S, Manku-Scott TK. Meeting patient expectations of care: the major determinant of satisfaction with out-of-hours primary medical care? Fam Pract 2002 Aug;19(4):333-8.

26. Moriarty $H$, McLeod $D$, Dowell $A$. Mystery shopping in health service evaluation. Br J Gen Pract 2003 Dec;53(497):942-6.

27. Dutch Health Care Inspectorate. Out of hours centres in the Netherlands show teething problems (Huisartsenposten vertonen nog veel kinderziekten). The Hague, 2004.

28. Dutch Health Care Inspectorate. Quality of out of hours centres improved since 2003 (Kwaliteit huisartsenposten verbeterd sinds 2003). The Hague, 2006.

29. Killip S, Ireson CL, Love MM, Fleming ST, Katirai W, Sandford K. Patient safety in after-hours telephone medicine. Fam Med 2007 Jun;39(6):404-9.

30. Whitson HE, Hastings SN, McConnell ES, Lekan-Rutledge DA. Interdisciplinary focus groups on telephone medicine: a quality improvement initiative. J Am Med Dir Assoc 2006 Sep;7(7):407-11. Epub 2006 Mar 23. 
31. Marklund $B$, Ström M, Månsson J, Borgquist L, Baigi A, Fridlund B. Computer-supported telephone nurse triage: an evaluation of medical quality and costs. J Nurs Manag 2007 Mar;15(2):180-7.

32. Black KL. Standardization of telephone triage in pediatric oncology. J Pediatr Oncol Nurs 2007 Jul-Aug;24(4):190-9.

33. Salisbury C, Trivella M, Bruster S. Demand for and supply of out of hours care from general practitioners in England and Scotland: observational study based on routinely collected data. BMJ 2000 Mar 320(7235):61821.

34. Hlahane MS, Greeff M, du Plessis E. Professional nurses' perceptions of the skills required to render comprehensive primary health care services. Curationis 2006 Nov;29(4):82-94.

35. Belman S, Chandramouli V, Schmitt BD, Poole SR, Hegarty T, Kempe A. An assessment of pediatric after-hours telephone care: a 1-year experience. Arch Pediatr Adolesc Med 2005 Feb;159(2):145-9.

36. Fatovich DM, Jacobs IG, McCance JP, Sidney KL, White RJ. Emergency department telephone advice. Med J Aust 1998; 169:143-146.

37. Hildebrandt DE, Westfall JM, Fernald DH, Pace WD. Harm resulting from inappropriate telephone triage in primary care. J Am Board Fam Med 2006 Sep-Oct;19(5):437-42.

38. Linda Kohn, Janet Corrigan, Molla Donaldson, (eds). To err is Human. Building a Safer Health System. Institute of Medicine. Committee on Quality of Health Care in America Institute of Medicine National Academy,Press Washington, D.C. 1999.

39. Raad voor Gezondheidsonderzoek. Advies Onderzoek Patiëntveiligheid Publicatie 48, Den Haag febr. 2005

40. Ranter H. Access to Air Safety Information. 2nd annual CIS \& Eastern Europe Airline Engineering \& Maintenance Conference, Budapest, October 9-10, 2002

41. Flin, R., Mearns, K., Fleming, M. \& Gordon, R. (1996). Risk Perception and Safety in the Offshore Oil and Gas Industry. Suffolk: HSE Books.

42. Joyner P. Why do people do what they do? - influencing the human factors in accidents at work. Presentation Hazards XIX International Symposium; Process safety and environmental protection. Manchester 2006.

43. Engelenburg P. Medische hulpverlening buiten kantooruren in Groot Den Haag: Van tegenspraak naar samenspraak. 1992. Thesis.

44. CJT van Uden, AJHA Ament, SO Hobma, PJ Zwietering,and HFJM Crebolder. Patient satisfaction with out-of-hours primary care in the Netherlands. BMC Health Serv Res 2005 Jan 15;5(1):6.

45. Moll van Charante EP, ter Riet G, Bindels P. Self-referrals to the A\&E department during out-of-hours: patients' motives and characteristics. Patient Educ Couns 2008 Feb;70(2):256-65. Epub 2007 Dec 11. 
46. Giesen P, Moll van Charante E, Mokkink H, Bindels P, van den Bosch W, Grol R. Patients evaluate accessibility and nurse telephone consultations in out-of-hours GP care: determinants of a negative evaluation. Patient Educ Couns 2007 Jan;65(1):131-6. Epub 2006 Aug 30.

47. Winston Churchill: "We shall not fail or falter". BBC radio broadcast, Feb 9, 1941.

48. Dutch Society of General Practitioners; Telephone guideline book Dec. 2007. Utrecht (NHG Telefoonwijzer).

49. Tijssen R. De "NHG-Telefoonwijzer": een goede leidraad voor triage? 2004 Nijmegen. Faculty of Medicine. UMC 045125.

50. Yanovski SZ, Yanovski JA, Malley JD, Brown RL, Balaban DJ. Telephone triage by primary care physicians. Pediatrics 1992 Apr;89 (4 Pt 2):701-6.

51. Crouch R. An investigation into the effects of a computer based decision support program on Accident and Emergency nurses' assessment strategies in telephone consultation. 2000 Thesis University of Surrey.

52. Edwards B. Telephone triage: how experienced nurses reach decisions. J Adv Nurs 1994 Apr;19(4):717-24.

53. Edwards B. Seeing is believing--picture building: a key component of telephone triage. J Clin Nurs 1998 Jan;7(1):51-7.

54. Leprohon J, Patel VL. Decision-making strategies for telephone triage in emergency medical services. Med Decis Making. 1995 JulSep;15(3):240-53.

55. Grol R. Beliefs and evidence in changing clinical practice. Personal paper BMJ 1997;315:418-21.

56. Kawamoto K, Houlihan CA, Balas EA, Lobach DF. Improving clinical practice using clinical decision support systems: a systematic review of trials to identify features critical to success BMJ $2005 \mathrm{Apr}$ 2;330(7494):765. Epub 2005 Mar 14.

57. Dale J, Williams S, Foster T, Higgins J, Snooks H, Crouch R, HartleySharpe C, Glucksman E, George S. Safety of telephone consultation for "non-serious“ emergency ambulance service patients. Qual Saf Health Care 2004 Oct;13(5):363-73.

58. Meer A, Simonin Ch, Trapp A, Niemann S, Abel T. Einfluss der medizinischen computerassistierten Telefontriage auf das Patientenverhalten: erste Erfahrungen in der Schweiz EMH 2003;84: $\mathrm{Nr}$ 41(Schweizerische Ärztezeitung).

59. Rethans JJ, Sturmans F, Drop R, van der Vleuten C, Hobus P. Does competence of general practitioners predict their performance? Comparison between examination setting and actual practice. BMJ 1991 Nov 30;303(6814):1377-80.

60. Ram P, van der Vleuten C, Rethans JJ, Schouten B, Hobma S, Grol R. Assessment in general practice: the predictive value of writtenknowledge tests and a multiple-station examination or actual medical 
performance in daily practice. Med Educ. 1999 Mar;33(3):197-203.

61. Lardner, R. and Fleming, M. (2002). Strategies to promote safe behaviour as a part of a health and safety management system. London: HSE Books.

62. Eedy DJ, Wootton R. Teledermatology: a review. Br J Dermatol 2001 Apr;144(4):696-707.

63. Taleb AC, Bohm GM, Avila M, Wen CL. The efficacy of telemedicine for ophthalmology triage by a general practitioner. J Telemed Telecare 2005;11 Suppl 1:83-5.

64. de Mul M, de Bont AA, Reus NJ, Lemij HG, Berg M. Improving the quality of eye care with tele-ophthalmology: shared-care glaucoma screening J Telemed Telecare. 2004;10(6):331-6.

65. Eminovic N, Wyatt JC, Tarpey AM, Murray G, Ingrams GJ. First evaluation of the NHS direct online clinical enquiry service: a nurse-led web chat triage service for the public. J Med Internet Res 2004 Jun 2;6(2):e17. 


\section{Summary}




\section{Chapter 1- Triage past and present}

General practitioners have reorganized primary care service during the out-of-hours period throughout the world. At large centres they work together with nurses or healthcare assistants who in many countries handle all incoming calls. These health care professionals are called triagists as they perform telephone triage. This means that they determine the urgency and any required care advice by telephone. In this chapter the care process of telephone triage and the objectives of this thesis are described.

Process description is a common procedure in many industrial organisations in order to identify errors that can be made during the execution of the process and to take action before errors are made. In this study an analysis of the process of telephone triage was made to identify critical points during this process. Three phases were identified. The first phase of asking questions about the clinical condition and personal situation of the patient. This phase of gathering information is followed by the second phase in which the triagist evaluates the answers to determine the level of urgency of the presented problem and the required care advice. The third phase follows in which the triagist makes a report to briefly document what has been discussed with the patient. To perform the different phases a triagist needs to have adequate clinical knowledge, good communication skills and the capability of summarizing and documenting a call.

The first objective of this thesis was to assess the quality of telephone triage at out-of-hours centres in the Netherlands, specifically the quality of clinical case handling, communication and reporting.

Research into the quality of communication by general practitioners in face-to-face contacts suggests that the duration of a consultation is correlated with the quality of communication. The second objective of this thesis was to determine whether there is a correlation between the duration of a call and the quality of communication of triagists. The research project was carried out by using standardised patients who called 17 different out-of-hours centres in the Netherlands regarding seven different medical problems. Each out-of-hours centre was called three times using these seven cases. 


\section{Chapter 2- Using Telephone Incognito Standardised Patients}

This chapter presents the feasibility and validity of using Telephone Incognito Standardised Patients (TISPs) in a primary care setting such as an out-of-hours centre. Also their training in role-playing and self-recording calls, made from their private residence, are described. The accuracy of role playing and the detection rate by triagists receiving the calls was assessed as this may have an impact on the management of the clinical case presented.

A team of 12 TISPs was trained to play their role and to self-record the calls with special equipment. They received information about their role and their fictitious identity and residence. At the training they spoke to a triagist and a general practitioner. Of the four or five calls made per evening, one call was assessed by two assessors independently for accuracy of role play on the following four criteria: 1) opening; 2) answers to questions asked by the triagist; 3 ) closing sentence conforming to instructions?; 4) was only information given if asked for? Retrospectively the out-of-hours centres were asked whether they had detected any calls made by a TISP. The TISPS filled in a questionnaire concerning their training, the self-recording technique and personal experiences.

The TISPs made 375 calls during 84 evenings. The accuracy of the role play was close to $100 \%$. On 11 occasions a TISP was called back on the same evening by a GP on call at the out-of-hours centre for additional information. Being able to call from home was highly appreciated by the TISPs although the self-recording caused extra tension for some of them. All fictitious calls remained undetected. The assessors reported that the quality of the recorded calls was excellent.

The method of using TISPs to assess aspects of telephone care is feasible, valid and reliable provided there is thorough training. The study shows that the 17 out-of-hours centres that were called for our study were approached in a relatively consistent way.

\section{Chapter 3- Development of the RICE-communication rating list}

This chapter deals with the development of an instrument to assess the communication skills of triagists. The objective was to develop a valid, reliable and feasible rating instrument.

A focus group was formed which existed of representatives of the four stakeholders involved in out-of-hours centres; patients, doctors, triagists and members of the management team. They all had experience with working at or with an out-of-hours centre. They developed a list containing 17 items. Each item describes another communication skill of telephone communication. The final product was entitled the RICE-communication rating instrument. The acronym 
RICE stands for the four successive phases of a call: "R" stands for: "Reason for calling"; "I" for: "Information to be gathered"; " $\mathrm{C}$ " for: "Care advice given"; "E" for: "Evaluation of the call". We chose the easy to remember acronym RICE because we felt it might help the call handler to remember the sequence of the successive phases of a call.

Experts with experience in training and evaluating communication skills of medical students and general practitioners commented upon the list to ensure content validity. They considered the list as complete and valid. The reliability of the list was tested in a pilot study in which 10 specially trained assessors scored six telephone calls each. The reliability of the list (Cronbach's alpha) was 0.73 which was considered to be acceptable. This instrument has been used to asssess all calls made for this study.

\section{Chapter 4- Quality of clinical case handling}

This chapter describes the investigation of the quality of telephone triage. The quality of the questions asked about the clinical condition, the triage outcome and the content of the home management and safety net advice were assessed. The last two items concern information about what patients can do themselves about the problem and when to call back to the out-of-hours centre.

The criteria for the cases to be presented were: 1) they should commonly present by telephone to an out-of-hours centre; 2) they should require urgent (i.e. to be seen for further investigation within 6 hours) or home care advice and 3) the design should demonstrate the importance of accurate history taking and correct evaluation of the answers.

Based on the results of a generalisability analysis each case had to be presented three times for reliability of assessment of case handling at an out-of-hours centre.

Expert panels of general practitioners developed standards for the clinical content of each of the seven cases and the scenarios to be played. They determined appropriate questions to be asked, desirable content of the home management and safety net advice, and the most appropriate outcome for each case. Telephone Incognito Standardised Patients (TISPs) made calls to present each of the seven cases on three occasions to 17 out-of-hours centres throughout the Netherlands. These out-of-hours centres were selected out of 98 centres that had given permission to be called. They were not informed that they had been selected. The number of out-of-hours centres per province was balanced against its population. The out-of-hours centres have been called between 7 and $9 \mathrm{pm}$ and these calls were self recorded by the TISPs for further 
assessment.

Triagists achieved the appropriate triage outcome in $58 \%$ of all calls. Of all questions asked a mean of $54 \%$ belonged to the category of obligatory questions suggested by the agreed standard. However, the overall mean percentage of obligatory questions asked before the urgency level was determined was $21 \%$ of the standard. In addition the answers to these questions were not always evaluated correctly. The quality of information regarding home management and safety net advice varied to a large extent per case but was overall of a low standard at all out-of-hours centres.

The results demonstrate that triagists very often reached conclusions after asking a minimal number of questions which means that they did not minimise the health risk to patients. History was not always taken efficiently and effectively as triagists often asked questions considered to be irrelevant for determining the urgency level.

In terms of enhancing the overall safety of telephone triage, apart from obtaining an appropriate clinical history, more adequate home management and safety net advice should be given. This is especially important if self care advice is given.

\section{Chapter 5- Quality of communication}

Chapter 5 presents the results of the assessments of the communication for 357 calls, made by the TISPs to the different out-of-hours centres. The calls were assessed with the RICEcommunication list. To evaluate the scores the items of the RICEcommunication list were divided over 3 clusters. Each cluster describes a basic communication skill. Cluster 1 describes active listening, cluster 2 active advising and cluster 3 structuring telephone consultation. The duration of each telephone consultation was measured and correlated with the quality of communication.

The mean overall score for communication skills was $35 \%$ of the maximum feasible score. The results for cluster 1 demonstrated that triagists asked correctly about medical aspects of the problem but asked very little about the personal situation of the patient and their perception of the problem or expectation. With regard to cluster 2, advice about the outcome of triage, home management or safety net advice was usually given without checking for patients' understanding and acceptance of the advice. Regarding cluster 3, calls were often handled in an unstructured way, without summarizing or clarifying the different steps within the consultation. There was a positive correlation of $0.86(p<0.01)$ between the overall communication score and the duration of the telephone consultation.

These results reveal specific shortcomings and aspects that could be focused on in training to improve the quality of communication skills 
at out-of-hours centres. Training in telephone consultation should aim more on patient-centred communication with active listening, active advising and structuring the call. Apart from adequate communication skills, triagists need sufficient time for telephone consultation to enable high quality performance. Research is needed to determine acceptable limits for the duration of calls while at the same time enabling effective and high quality communication.

\section{Chapter 6- Quality of reports}

Documenting what has been discussed with the patient is the third and final step in the process of telephone triage. A high quality record for what has been discussed with the patient is essential for continuity of care and for medicolegal purposes.

Chapter 6 presents the results of the assessments of the reports of the calls made by the TISPs and to what extent the reports reflected the telephone consultation.

After the focus group had developed the RICE-communication list (chapter 3), the focus group also developed the RICE-report instrument. With this tool the quality of the information in reports of telephone triage can be assessed (the acronym RICE stands for: Reason for calling, Information gathered, Care advice given, Evaluation of care advice). The instrument consists of two parts: 1) the case specific part with the obligatory questions to be asked and the care advice given and 2) the patient specific part with information on patients' personal situation, expectation and evaluation of the care advice. Each call was transcribed. After the study the out-ofhours centres were asked for a copy of the reports of the calls. The quality of the reports was assessed with the RICE-report instrument and the content of the reports was compared with the content of the transcripts.

The out-of-hours centres returned a report for $78 \%$ of the 357 calls. For the remaining $22 \%$ of the calls no report was written. Reports contained information on the medical reason for calling in most cases but little information on previous medical history. Patients' expectation or personal situation were seldom documented. Patients' evaluation of the care advice was mentioned regularly at two out-ofhours centres, at the others not at all .

In all but two out-of-hours centres triagists reported answers to notasked obligatory questions varying from 2 to $54 \%$ of all questions entered. Triagists entered a subjective evaluation of patients' condition in $12 \%$ of the reports when they entered remarks like "No alarming signals" or "No other complaints". By comparing the transcripts with the reports the assessors could not identify which questions were asked to support those remarks. 
We concluded that reports of telephone consultations of out-of-hours centres contained little information on patients' clinical and personal condition. This may potentially endanger patients' continuity of care and might pose legal consequences for the triagist and the organisation of the $\mathrm{OOH}$ centre.

\section{Chapter 7- General discussion}

Chapter 7 presents the main findings and methodological aspects of the studies described in this thesis. Recommendations to improve the quality of telephone triage are given as well as advice on further research.

The results of the thesis show the feasibility of introducing Telephone Incognito Standardised Patients. They performed very accurately and presented their clinical cases in a relatively consistent way.

The analysis of the triage process identified critical points in telephone triage to be observed. Knowledge of these critical points may allow opportunities to prevent errors. The results for the quality of three aspects, clinical and communication skills, and documentation of calls, identified shortcomings and learning points for the process of telephone triage.

The high safety standards in the petrochemical and aviation industries might be useful to apply in telephone triage both for clinical case handling and also for documenting the telephone consultation. The results also illustrate the need for training in patient-centred communication.

A computer based clinical decision support system that meets the demands for high quality support for triagists at each phase of the telephone triage needs to be developed and investigated. Knowledge about the implementation and usage of such a system is essential. 
Samenvatting 


\section{Inleiding}

Voor dit onderzoek naar de kwaliteit van telefonische triage op een huisartsenpost werd gebruik gemaakt van Telefonische Incognito Standaard Patiënten (TISP's) en werden drie kwaliteitsaspecten van telefonische triage onderzocht. De methodiek die daarbij werd gevolgd en de bevindingen worden in deze Nederlandstalige versie uitgebreider beschreven dan in de Engelstalige Summary. Dit is gedaan speciaal voor diegenen die het prettiger vinden in het Nederlands dan in het Engels over dit onderzoek te lezen.

\section{Hoofdstuk 1: Analyse van het proces telefonische triage}

Wereldwijd organiseren huisartsen eerstelijnszorg buiten kantooruren vanuit centrale huisartsenposten. Zij werken samen met verpleegkundigen of doktersassistenten die in veel landen alle telefonisch verzoeken om medisch advies beantwoorden. Zij doen de telefonische triage en worden daarom triagisten genoemd. Telefonische triage is het zorgproces waarin voor een medisch probleem telefonisch de mate van urgentie en de bijpassende zorg wordt bepaald.

Alvorens de doelstellingen van dit onderzoek te formuleren wordt eerst het proces van telefonische triage beschreven. Dit naar analogie van goede ervaringen die zijn opgedaan met procesbeschrijving elders zoals in de productie-industrie. Daar wordt ieder productieproces tot in details geanalyseerd om fouten die tijdens de productie kunnen optreden, voortijdig op te sporen. De kennis die men daarmee verkrijgt maakt het mogelijk te bepalen welke actie ondernomen moet worden om die fouten te voorkomen. Aan de hand van deze analyse werd het proces telefonische triage verdeeld in drie fasen. Een eerste fase waarin de triagist informatie verzamelt over de lichamelijke en persoonlijke situatie van de patiënt. In fase twee wordt de betekenis van de antwoorden ingeschat om de ernst van het probleem te bepalen en de patiënt te informeren over de bijpassende zorg. In fase drie legt de triagist in een verslag vast wat met de patiënt is besproken.

Uit deze analyse volgt dat de kwaliteit van telefonische triage bepaald wordt door de medische kennis, de communicatieve vaardigheid en de verslaglegging.

De eerste doelstelling van deze studie was: in welke mate voeren triagisten op huisartsenposten in Nederland deze drie kwaliteitsaspecten van telefonische triage uit, gemeten naar hedendaagse normen.

Uit onderzoek onder huisartsen is gebleken dat de kwaliteit van de communicatie tussen arts en patiënt correleert met de lengte van het consult. De tweede doelstelling van deze studie was te bepalen of 
een dergelijke correlatie tussen de duur van een telefonisch consult en de kwaliteit van de communicatie van een triagist kon worden vastgesteld.

Voor de uitvoering van dit onderzoek belden 12 TISP's naar 17 verschillende huisartsenposten voor zeven medische problemen en iedere huisartsenpost werd hiervoor drie maal gebeld.

In hoofdstuk 2 wordt bericht over de voorbereiding en training van de TISP's en de nauwkeurigheid waarmee zij hun rol hebben gespeeld.

In hoofdstuk 3 wordt de totstandkoming en validatie van de HAAKcommunicatie score lijst beschreven. Dit is het instrument waarmee de kwaliteit van communicatie van triagisten kan worden bepaald.

De validatie van de standaarden voor de zeven casus met de bijbehorende speelscenario's voor de TISP's wordt beschreven, evenals de wijze waarop de 17 huisartsenposten zijn geselecteerd. Vervolgens worden in hoofdstuk 4 en 5 de resultaten van de beoordeling van de medische en communicatieve vaardigheden van triagisten gepresenteerd.

Nadat alle gesprekken waren gevoerd werd alle deelnemende huisartsenposten gevraagd een kopie van het (waarneem)verslag te sturen. In hoofdstuk 6 worden de resultaten van de beoordelingen van die verslagen gepresenteerd.

In hoofdstuk 7 worden de voornaamste bevindingen samengevat en tot welke conclusies die hebben geleid. $\mathrm{Na}$ een terugblik op methodologische aspecten van dit onderzoek worden aanbevelingen gedaan voor verbeteringen en verdere studies op het gebied van telefonische triage op een huisartsenpost. 


\section{Hoofdstuk 2: Nauwkeurigheid van rollenspel}

In dit hoofdstuk wordt nader ingegaan op het inzetten van Telefonische Incognito Standaard Patiënten (TISP's). Beschreven wordt hun voorbereiding, de nauwkeurigheid waarmee ze hun rollen hebben gespeeld en of ze ontdekt werden.

Een team bestaande uit twee ervaren triagisten en één huisarts trainde 14 TISP's zeven verschillende rollen te spelen. De intentie was om twee TISP's met dezelfde rol afwisselend te laten bellen naar huisartsenposten om de kans op ontdekking door spraakherkenning door een triagist te verkleinen. Dat lukte voor vijf van de zeven rollen doordat op het laatste moment twee TISP's om persoonlijke redenen uitvielen. Besloten werd geen nieuwe TISP's te trainen.

De TISP's ontvingen scenario's met daarin uitgebreide informatie over het medische probleem, hun verzonnen identiteit en de locatie waar ze zich zogenaamd die avond bevonden. Ze leerden nonverbale gevoelens als ongerustheid, onzekerheid of angst hoorbaar te presenteren en om de gesprekken thuis zelf op te nemen met speciale apparatuur.

Om zeker te zijn dat alle noodzakelijke informatie over de huisartsenposten in het scenario van de TISP's vermeld stond belde een lid van het trainingsteam alle 17 geselecteerde huisartsenposten. Het bleek dat sommige huisartsenposten naar de postcode van het (zogenaamde) verblijfsadres vroegen. Deze informatie ontbrak nog in het scenario.

De nauwkeurigheid waarmee TISP's hun rol spelen kan van grote invloed zijn op de manier waarop een consult wordt gevoerd. Het onderzoeksteam stelde vier criteria samen om de nauwkeurigheid van hun rollenspel te bepalen: waren 1) openingszin; 2) antwoorden op vragen en 3) slotzin conform het script?; 4) werd alleen informatie gegeven als erom gevraagd werd?

Om te testen of de TISP's hun rol nauwkeurig speelden, belden ze een medisch call center voor hetzelfde probleem als waarvoor ze tijdens het onderzoek zouden bellen. De medewerkers van het call center wisten dat ze met een TISP spraken maar ze speelden het spel mee en voerden de telefonische consultatie op gebruikelijke wijze uit. Deze oefengesprekken werden door het onderzoeksteam beoordeeld op nauwkeurigheid van rollenspel en de conclusie was dat de TISP's klaar waren voor het onderzoek.

Tijdens het onderzoek belden de TISP's met een interval van zes weken en steeds op een andere dag van de week. Dit werd gedaan om twee redenen: ten eerste om de kans op spraakherkenning en dus ontdekking te verkleinen en ten tweede om de kans te vergroten zoveel mogelijk verschillende triagisten te spreken. Ze belden vanuit hun thuissituatie tussen 7 en 9 uur s'avonds naar 
vier tot vijf huisartsenposten. Voor één van deze opgenomen gesprekken bepaalden twee beoordelaars onafhankelijk van elkaar hoe nauwkeurig de TISP's hun rol hadden gespeeld aan de hand van de vier criteria. $\mathrm{Na}$ afloop van het onderzoek werden de huisartsenposten die gebeld waren, gevraagd of zij het vermoeden hadden door een TISP te zijn gebeld. Nadat was vastgesteld dat alle benodigde telefoontjes goed waren opgenomen werd de TISP's verzocht een enquête in te vullen met vragen over hun training en het zelf opnemen van de gesprekken.

Er waren 357 gesprekken gepland maar de TISP's voerden 375 gesprekken tijdens 84 avonden omdat bij 18 gesprekken de opname was mislukt. Deze laatste gesprekken moesten opnieuw worden gevoerd. Ze behaalden een bijna $100 \%$ score voor nauwkeurigheid van rollenspel. Het gebeurde 11 maal dat een TISP dezelfde avond werd teruggebeld door de dienstdoende huisarts voor nadere informatie. De TISP's hebben de mogelijkheid om van thuis uit te kunnen bellen zeer gewaardeerd maar het zelf opnemen van de gesprekken heeft bij sommige TISP's extra spanning veroorzaakt. Geen enkele huisartsenpost gaf aan een TISP ontdekt te hebben. De beoordelaars kwalificeerden de kwaliteit van de opnames als uitstekend.

Onze conclusie is dat TISP's zeer goed ingezet kunnen worden om onderzoek te doen naar telefonische hulpverlening door een zorginstelling zoals een huisartsenpost. Dit nadat ze zorgvuldig getraind en voorbereid zijn. Tevens concludeerden we dat de huisartsenposten tijdens dit hele onderzoek op een consistente manier zijn benaderd.

\section{Hoofdstuk 3: De HAAK-communicatie score lijst}

Om de communicatieve vaardigheid van triagisten te bepalen was het nodig te beschikken over een valide, betrouwbaar en praktisch bruikbaar instrument. In dit hoofdstuk wordt ingegaan op de totstandkoming ervan.

Een focusgroep werd geformeerd om dit beoordelingsinstrument samen te stellen. Ze bestond uit vertegenwoordigers van die partijen die nauw bij het werk van een huisartsenpost betrokken zijn; patiënten, artsen, triagisten en leidinggevenden van een huisartsenpost. Ze stelde een lijst samen met 17 items waarbij ieder item een bepaalde communicatieve vaardigheid beschrijft. Voor validering van de inhoud werd de lijst voorgelegd aan twee deskundigen op het gebied van training in communicatie aan artsen en medische studenten. Zij beoordeelden deze lijst als volledig en valide. Dit instrument heet de HAAK-communicatie score lijst. 
De letters HAAK geven de opeenvolgende fasen van een gesprek aan: $\mathrm{H}$ staat voor fase 1: Hulpvraag; $\mathrm{A}$ voor fase 2: Achtergrond informatie; $A$ voor fase 3:Advies en $\mathrm{K}$ voor fase 4: Klant (=patiënt) reactie.

Om de betrouwbaarheid van de HAAK-lijst te bepalen werden 10 ervaren triagisten opgeleid. $\mathrm{Zij}$ beoordeelden onafhankelijk van elkaar zes (geanonimiseerde) op een huisartsenpost opgenomen gesprekken met de HAAK-lijst. De betrouwbaarheid van de lijst (Cronbach's alpha) was 0.73 .

\section{Hoofdstuk 4 en 5}

Inleiding

Deresultaten van de beoordeling van de medische en communicatieve vaardigheid van triagisten worden respectievelijk in hoofdstuk 4 en 5 gepresenteerd. Uitgangspunt voor deze beoordelingen was het gesprek waarin de TISP een medisch probleem voorlegde aan een huisartsenpost. Aangezien de TISP's steeds voor dezelfde medische problemen naar dezelfde huisartsenposten hebben gebeld, wordt eerst ingegaan op de gepresenteerde casuïstiek en de selectie van de huisartsenposten.

\section{Casuïstiek}

De criteria waaraan de casuïstiek moest voldoen, waren ten eerste: "er moet regelmatig voor een dergelijk probleem naar een huisartsenpost worden gebeld"; ten tweede "de uitkomst van triage kan om praktische redenen niet leiden tot een spoedgeval of huisvisite"; ten derde "de casus zijn zodanig samengesteld dat onderzocht kan worden of de anamnese zorgvuldig is uitgevoerd" en ten vierde of "de betekenis van de antwoorden op de juiste wijze werd ingeschat".

Een panel van ervaren huisartsen stelde voor iedere casus een standaard vast met daarin de medisch inhoudelijke vragen die gesteld moesten worden en de inhoud van het zelfzorg- en vangnetadvies. Een zelfzorgadvies beschrijt wat de patiënt zelf aan het probleem kan doen en een vangnetadvies geeft aan waar de patiënt de komende uren op moet letten en wanneer hij moet terug-bellen. Beide adviezen worden alleen gegeven als de patiënt de komende uren niet nader onderzocht zal worden. Voor iedere casus werd het scenario voor de TISP's samengesteld met daarin de antwoorden die zij moesten geven op vragen van een triagist. Een groep van 12 huisartsen valideerde deze scenario's en bepaalde voor iedere casus de gewenste mate van urgentie. Dit kon zijn het advies om dezelfde avond naar de huisartsenpost te komen voor nader onderzoek of om het verdere verloop af te wachten. 


\section{Huisartsenposten}

In 2004 kende Nederland 105 huisartsenposten. Zij werden per brief verzocht toestemming te geven om voor ons onderzoek te worden geselecteerd. Van de 98 huisartsenposten die toestemming gaven werden er 17 geselecteerd, verspreid over Nederland. Het aantal te selecteren huisartsenposten per provincie werd berekend naar rato van de omvang van haar bevolking en de selectie werd at random per provincie bepaald. De huisartsenposten werden niet geïnformeerd dat ze geselecteerd waren.

Om een betrouwbare uitspraak over de kwaliteit van telefonische triage per huisartsenpost te kunnen doen werd een generalisatie analyse uitgevoerd. De TISP's belden vijf maal voor de zeven casus naar vijf van de 17 huisartsenposten en de kwaliteit van de communicatie en de medische afhandeling werd beoordeeld. De analyse wees uit dat iedere casus driemaal moest worden aangeboden en dat ieder gesprek door twee personen moest worden beoordeeld. Voor de uiteindelijke beoordeling van de kwaliteit van alle gesprekken gebruikten we de scores van de eerste drie gesprekken naar deze vijf posten gecombineerd met de scores van de gesprekken naar de overige 12 huisartsenposten.

De 17 huisartsenposten werden tussen 7 en 9 uur s'avonds gebeld. De gesprekken werden opgenomen en van alle gesprekken werd een verbatim gemaakt.

Voor de kwaliteit van de medische vaardigheden van triagisten beoordeelden twee medische studenten ieder gesprek onafhankelijk van elkaar. Zij maakten gebruik van de verbatims en ze beoordeelden de kwaliteit aan de hand van checklisten, die gebaseerd waren op de standaarden. Bij dit onderzoek waren in totaal vier medische studenten betrokken, allen $4^{\text {de }}$ jaars.

Voor de kwaliteit van de communicatie beoordeelden twee ervaren triagisten onafhankelijk van elkaar elk gesprek. Zij luisterden naar het opgenomen gesprek en ze konden gebruikmaken van het verbatim. Voor het scoren gebruikten ze de HAAK-communicatie lijst. In totaal waren 11 triagisten bij dit onderzoek betrokken.

\section{Hoofdstuk 4: Kwaliteit van medische vaardigheden}

De kwaliteit van de gestelde vragen, de inhoud van het zelfzorgen vangnetadvies en de geadviseerde urgentie werd onderzocht. De resultaten van de beoordelingen worden in dit hoofdstuk gepresenteerd.

Van alle gestelde vragen behoorde gemiddeld $54 \%$ tot de categorie verplichte vragen. Echter, van de verplichte vragen die in de standaarden vermeld stonden, werd gemiddeld $21 \%$ gesteld. Niet altijd werd het belang van een antwoord op een vraag op de juiste 
wijze ingeschat, zowel niet door triagisten als door huisartsen die een TISP terugbelden. De kwaliteit van de zelfzorg- en vangnetadviezen varieerde sterk per casus en was op alle huisartsenposten beperkt. Triagisten bepaalden voor $58 \%$ van alle gesprekken de gewenste urgentie, voor $41 \%$ was het urgentieniveau te laag en voor $1 \%$ te hoog ingeschat.

Op grond van onze bevindingen concludeerden we dat triagisten niet altijd efficiënt en effectief de anamnese afnamen want zij stelden vaak vragen die voor de urgentiebepaling niet relevant waren. Tevens stelden we vast dat triagisten zeer vaak een zorgadvies gaven na het stellen van een zeer beperkt aantal verplichte vragen waardoor een mogelijk gezondheidsrisico voor de patiënt niet tot een minimum werd beperkt.

We adviseren dat voor veilige telefonische triage, zeker als een zelfzorgadvies wordt gegeven, de anamnese zorgvuldiger wordt afgenomen en dat meer aandacht aan het zelfzorg- en vangnetadvies wordt besteed.

\section{Hoofdstuk 5: Kwaliteit van communicatieve vaardigheden}

In dit hoofdstuk worden de resultaten beschreven van de beoordeling van de kwaliteit van de communicatie en de correlatie tussen deze kwaliteit en de gesprekstijd.

De gesprekken werden beoordeeld aan de hand van de HAAKcommunicatie lijst. Om de resultaten te interpreteren werden de 17 items van deze lijst verdeeld over negen sub clusters en deze negen werden verdeeld over drie clusters. leder cluster beschrijft een basisvaardigheid van (telefonische) communicatie. Cluster 1 actief luisteren; cluster 2 actief adviseren en cluster 3 gestructureerd communiceren. Voor ieder gesprek werd de duur van het telefonisch consult vastgelegd. De tijd die nodig was om persoonsgegevens van de patiënt op te nemen, werd niet meegerekend.

De gemiddelde score voor alle items van de HAAK-communicatie lijst was $35 \%$ van de maximaal haalbare score. Triagisten stelden op correcte wijze de medisch inhoudelijke vragen. Ze vroegen niet of nauwelijks naar de persoonlijke situatie van de patiënt zoals diens verwachting of beleving van het probleem. Het zorgadvies en de zelfzorg- of vangnetadviezen werden meestal gegeven zonder controle op acceptatie en of de patiënt het advies had begrepen. De meeste gesprekken verliepen zonder herkenbare structuur en zonder dat de patiënt werd geïnformeerd over het verloop van het telefonisch consult. Er was een significant positieve correlatie van $0.86(p<0.01)$ tussen de duur van het telefonisch consult en de totale score voor communicatieve vaardigheid.

De wijze waarop patiënten en artsen met elkaar communiceren is de 
afgelopen decennia ingrijpend veranderd. Vroeger spraken artsen voornamelijk ziektegericht, tegenwoordig dienen ze patiëntgericht te communiceren. Niet de ziekte maar de patiënt die zich ziek voelt, staat centraal. De resultaten van dit onderzoek wijzen erop dat de communicatie op huisartsenposten (nog) niet geheel voldoet aan de eisen van moderne communicatie. Training in communicatieve vaardigheid van triagisten dient aandacht te besteden aan meer patiëntgericht en niet uitsluitend ziektegericht communiceren. Behalve training in goede communicatieve vaardigheden dienen triagisten voldoende tijd te krijgen om een kwalitatief goed gesprek te kunnen voeren.

\section{Hoofdstuk 6: Kwaliteit van het verslag}

In dit hoofdstuk worden de resultaten besproken van de beoordelingen van de kwaliteit van de verslagen van de gesprekken naar de huisartsenposten. Tevens is onderzocht in welke mate de verslagen een weergave waren van hetgeen was besproken.

Het verslag is van belang voor de continuïteit van zorg, het kan een rol spelen bij juridische procedures en het kan gebruikt worden voor epidemiologisch onderzoek.

Nadat de focusgroep de HAAK-communicatie lijst had samengesteld (hoofdstuk 3) stelden zij de HAAK-verslag lijst samen waarmee de kwaliteit van de inhoud van verslagen van telefonische consulten kan worden bepaald. De lijst bevat een casus- en een patiëntgerelateerd deel. Het casus gerelateerde deel bevat de vragen die gesteld moeten worden en het zorgadvies dat moet worden gegeven. De inhoud van dit deel is afhankelijk van het probleem waarvoor de patiënt belt. In het patiëntgerelateerde deel worden diens verwachting, persoonlijke situatie en reactie op het zorgadvies vastgelegd en dit is probleem onafhankelijk. $\mathrm{Na}$ afloop van het onderzoek werden alle betrokken huisartsenposten verzocht een kopie van het (waarneem) verslag van het gesprek met de TISP te sturen. De kwaliteit van deze verslagen werd door twee huisartsen onafhankelijk van elkaar beoordeeld aan de hand van de HAAK-verslag lijst.

Door de huisartsenposten werd voor 278 van de 357 gesprekken een verslag gestuurd. Dit is $78 \%$ van het verwachte aantal. Voor de resterende $22 \%$ van de gesprekken was geen verslag gemaakt. De verslagen vermeldden bijna altijd de medische reden waarvoor werd gebeld en gaven weinig anamnestische informatie. De verwachting en de persoonlijke situatie werden zelden genoteerd. Het oordeel van de patiënt aangaande het gegeven zorgadvies werd door twee huisartsenposten regelmatig vermeld, op de overige huisartsenposten geheel niet. 
Vergelijkingen tussen verslagen en verbatims leidden tot twee opmerkelijke bevindingen. Ten eerste, triagisten hadden, met uitzondering van één huisartsenpost, soms antwoorden op verplichte vragen genoteerd hoewel ze niet waren gesteld. Dit betekent dat de huisarts, die als eindverantwoordelijke het besluit van een tria-gist moet fiatteren, over onjuiste informatie beschikte. Ten tweede, in $12 \%$ van de verslagen stonden opmerkingen als "Geen alarmsignalen" of "Geen andere klachten". Uit de vergelijking tussen de betreffende verslagen en de verbatims konden de beoordelaars echter niet bepalen waarop deze beweringen berustten. Dit betekent dat triagisten voor die gesprekken een subjectieve interpretatie van de lichamelijke situatie van de patiënt hadden genoteerd.

Onze conclusie is dat de verslagen van de telefonische consulten weinig en niet altijd betrouwbare informatie bevatten over de fysieke en persoonlijke situatie van de patiënt. Dit kan een negatieve rol spelen voor de continuïteit van zorg en tevens juridische gevolgen hebben voor een triagist en de organisatie van de huisartsenpost.

\section{Hoofdstuk 7: Algemene discussie}

In dit hoofdstuk worden de voornaamste bevindingen van dit onderzoek gepresenteerd en wordt stilgestaan bij de methodiek van ons onderzoek. Tevens wordt aangegeven tot welke conclusies de bevindingen hebben geleid. Tot slot worden aanbevelingen en onderzoeksvoorstellen gedaan om de kwaliteit van telefonische triage te verbeteren.

De procesanalyse van telefonische triage maakte zichtbaar op welke momenten fouten gemaakt kunnen worden. Dit inzicht is nodig om maatregelen te bedenken hoe die fouten voorkomen kunnen worden. De resultaten van dit onderzoek tonen tekortkomingen die kunnen optreden tijdens ieder van de drie verschillende fasen van dit proces. Deze tekortkomingen zijn naar onze mening goed te verhelpen.

Als onderzoeksresultaat vermelden we ten eerste dat de TISP's hun telefoonrol zeer nauwkeurig hebben gespeeld. Dat betekent dat zij de huisartsenposten op een consistente wijze hebben gebeld.

In navolging van de eisen ten aanzien van veiligheid zoals die in de petrochemische industrie en de vliegwereld gelden, dient ook voor telefonische triage een "cultuur van veiligheid' te ontstaan. Ook dienen triagisten getraind te worden om op een meer patiëntgerichte wijze telefonisch te communiceren.

Het verdient aanbeveling onderzoek te doen naar instrumenten die de kwaliteit en veiligheid van telefonische triage kunnen ondersteunen. Hierbij kan gedacht worden aan computer gestuurde beslissingsondersteunende systemen. Onderzocht moet worden aan welke eisen deze systemen moeten voldoen en welke hindernissen 
overwonnen moeten worden om ze effectief in te zetten. Tot slot dient onderzocht te worden op welke wijze een juist gebruik gegarandeerd kan worden.

Het onderzoeksteam hoopt met deze thesis een bijdrage te leveren aan zorg-per-telefoon van hoge kwaliteit met aandacht voor veiligheid tijdens medische beoordeling, patiëntgerichte communicatie en betrouwbare informatieve verslaglegging. 


\section{DANKWOORD}

Werken aan een proefschrift is als het maken van een pittige bergtocht. Je bereidt je zo goed mogelijk voor, je sterft een paar keer onderweg maar uiteindelijk bereik je de top en mag je genieten van het uitzicht. Ik sta nu aan de vooravond van de verdediging van dit proefschrift en dus vlak onder de top. Toen ik als volstrekt onervaren onderzoeker aan dit promotietraject begon, wist ik bij lange na niet wat me allemaal te wachten stond. Dank zij de steun en inbreng van velen die ik tijdens dit onderzoek ontmoette, gelukte het me toch op koers te blijven. Om te voorkomen dat ik iemand van hen vergeet, mijn dank aan allen die me de afgelopen jaren in woord en daad hebben geholpen bij de totstandkoming van dit proefschrift. Enkele van hen wil ik in het bijzonder danken.

Op de eerste plaats mijn promotor, André Knottnerus. Welk een eer en genoegen was het om onder jouw inspirerende leiding aan dit onderzoek te werken. Op subtiele en uiterst scherpzinnige wijze stond je me terzijde waarbij de zeer persoonlijke touch na afloop van iedere vergadering je warme persoonlijkheid liet zien.

Jan Joost Rethans, co-promotor, vanaf het eerste moment merkte ik dat je geloofde in dit onderzoek en was je zichtbaar enthousiast. Je loodste mij, volstrekt groentje, op handige en deskundige wijze langs allerlei valkuilen van wetenschappelijk onderzoek. Ik kijk terug op een gezellige en kameraadschappelijke samenwerking waarbij je steeds zeer alert de wetenschappelijke kwaliteit van mijn werk bewaakte. Geduldig leerde je me geduld te tonen.

Arno Muijtjens, als co-promotor kwam je in de laatste fase van het onderzoek bij ons team. Jouw inbreng was uiterst belangrijk. Je maakte me wegwijs in het doolhof van statistiek en vol geduld legde je me steeds weer uit wat we nu eigenlijk wel en vooral ook niet hadden gevonden. Het plezier dat je toonde in het goochelen met onze bevindingen hielp me om 'domme' vragen te blijven stellen. Ron Hoogenboom, ook jou dank ik van harte. Jij maakte de statistische analyses mogelijk waarbij je uiterst bescheiden maar zeer deskundig en met monnikengeduld mij steeds weer bestookte met zeer terechte vragen.

Bas Maiburg en Ron Winkens, leden van de studiegroep voor dit onderzoek. De inbreng van jullie kennis en kunde was zeer zinvol. Bas, de gesprekken op de gang leidden steeds weer tot aanscherping van het onderzoek. Ron, je hulp in de latere fasen 
van het onderzoek bij het opbouwen van de artikelen heb ik zeer gewaardeerd. Je maakte er geen enkel punt van om hiervoor een reis vanuit het westen naar het zuiden te onderbreken.

Henk Hoogland, je loodste me de universiteit van Maastricht binnen. Je zoektocht naar risico-analyses was voor mij bij het begin van mijn onderzoek een raadsel. Ik denk dat ik het nu beter begrijp.

Frans van Wijmen, bedankt dat je een treinreis wilde onderbreken om midden in het Brabantse land juridisch advies te geven over voetangels en klemmen bij de uitvoering van dit onderzoek.

Leden van de beoordelingscommissie, Job Metsemakers, Jan de Haan, Cees van Vleuten, Jan van Dalen en Yvonne van Leeuwen, ik dank jullie voor de positieve feedback en waardevolle suggesties.

A special word to my British colleagues Jeremy Dale, Rob Crouch and Mark Vorster. Meeting you meant encountering the world of telephone triage. Jeremy and Rob, your research inspired me to write this thesis. Mark, your great help with transforming my English text into a correct English version has been highly appreciated. I am looking forward to our continued cooperation.

Om wetenschappelijk onderzoek te doen zijn ambitie en interesse niet voldoende. Je moet ook de mogelijkheid krijgen. Medicinfo bood mij alle ruimte. Een woord van dank aan alle medewerkers van Medicinfo op wie ik steeds kon terugvallen en die eindeloos allerlei verhalen wilden aanhoren. Een speciaal woord van dank aan Arno van Son, directeur van Medicinfo, die mij in alle opzichten vanaf het begin steunde. Arno, zonder jouw steun was dit onderzoek bij een interessant idee gebleven.

Liesbeth en Sylvia, dank voor het vele werk dat jullie deden achter de schermen: van data-administratie tot het schrijven van verbatims. Bart en Marijke, dank voor jullie kritische blikken op alle teksten. Willem en Joep: jullie leerden me de beginselen van procesanalyses en hielpen daardoor mee om dit onderzoek op de rails te krijgen. Saskia, bedankt voor je prachtige ontwerp van de kaft en alle hulp bij de totstandkoming van dit boekje.

Ik dankte tot nu toe hen die mij wetenschappelijk hebben gesteund of mij de ruimte boden om dit onderzoek te doen. Daarnaast was er een grote groep mensen en organisaties die onmisbaar waren voor de uiteindelijke resultaten. Ik dank de leden van de focusgroep en de huisartsen die in verschillende panels zaten. In een vroeg stadium 
van dit onderzoek leverden jullie een bijdrage aan iets wat nog ver weg leek. Ook dank ik de 98 huisartsenposten die bereid waren mee te werken aan dit onderzoek en speciaal de 17 huisartsenposten die de verslagen van de gesprekken met onze Telefonische Incognito Standaard Patiënten (TISP's) stuurden.

Ik dank de TISP's. Jullie speelden vol overgave jullie rol zonder ook maar één keer te worden ontdekt. Daarbij namen jullie de gesprekken zelf op wat voor sommige van jullie een zwaardere taak was dan het spelen van de rol. De gezelligheid die ik steeds heb ervaren als ik bij jullie thuis de gesprekken kopieerde naar mijn laptop zal ik niet gauw vergeten. De koffie stond overal klaar met twee koekjes bij Wiel.

Anjo, Arja, Trees, Fang, Wiel, Theo, Iris, Chantal, Paulien, Mirjam, Wies, Tilly, hartelijk dank voor jullie inzet en de fijne samenwerking.

De gesprekken en de beoordelingen ervan vormden de kern van de resultaten van het onderzoek. Linda, Christel, Irene en Marloes, meestal per kerende post beoordeelden jullie de medische inhoud van de gesprekken. Soms deden jullie dat aan de andere kant van de wereld. Dank voor jullie nauwgezet werk en succes met jullie medische studie. Laten we bij gelegenheid weer iets drinken op het Vrijthof.

Dank aan de medische centralisten van Medicinfo die alle gesprekken op de kwaliteit van de communicatie hebben beoordeeld. Agnes, Angela, Corine, Desiree, Diana, Edith, Hetty, Karin, Margo en Nathalie. Nooit deed ik vergeefs een beroep op een van jullie. Een speciaal woord van dank aan Estelle die niet alleen vele gesprekken beoordeelde, maar ook de intensieve training van de TISP's op creatieve wijze verzorgde. Met plezier denk ik terug aan onze tochtjes door het mooie Zuid-Limburgse land waar ook jij zichtbaar van genoot.

De onzichtbare groep van 45 adreshouders dank ik hartelijk. Jullie stelden jullie adresgegevens beschikbaar en zorgden zeer nauwgezet voor de betaling van de rekeningen van huisartsenposten. Dank voor jullie medewerking die er mede toe heeft bijgedragen dat onze TISP's niet werden ontdekt.

Promoveren is een kostbare zaak. Ik dank Medicinfo, CZ Actief in Gezondheid, VGZ en de VVAA voor hun financiële bijdrage aan dit onderzoek. 
Op een dag als deze gaan mijn gedachten zeker ook naar mijn overleden ouders en broer. Pap, mam en Markus, wat had ik graag deze dag met jullie beleefd.

Tot slot dank ik drie mensen die een onbeschrijfelijke steun zijn geweest bij de totstandkoming van dit proefschrift.

Andreas Meer, unsere Unterhaltungen in der Schweiz, England, Italien oder in Holland waren immer inspirierend und haben mir geholfen das Begriff Telefonische Triage etwas besser zu verstehen. Täglich realisiere auch Ich mich wie kompliziert es oft ist.

Harrie van Rooij, zonder jou was het waarschijnlijk nooit zo ver gekomen. Vanaf het eerste moment dacht je uiterst kritisch mee over iedere stap die we moesten zetten. Onze tochten door het land om de locaties te fotograferen van waaruit de TISP's zogenaamd moesten bellen zal ik nooit vergeten. Vaak kwam ik s'avonds bij je thuis om aan het onderzoek te werken met een groot vraagteken op mijn voorhoofd: 'hoe verder'? Als ik dan enkele uren later naar huis reed, vond ik het zonde om te moeten gaan slapen, zo inspirerend waren onze gedachtewisselingen. Harrie, jouw inbreng en niet aflatende support waren uniek en subliem. Deze dag hoort ook jou toe!

En Ine, jij was er altijd. The rest remains silent. 


\section{CURRICULUM VITAE}

Hay Derkx werd geboren te Jakarta, Indonesië, op 24 september 1949. In 1968 deed hij eindexamen gymnasium $\beta$ aan het

St.Willibrorduscollege Katwijk de Breul te Zeist waarna hij geneeskunde studeerde aan de St. Radboud Universiteit te Nijmegen. Hij deed een aantal co-schappen in Biharamulo, Tanzania, en zijn belangstelling voor de tropen kreeg na zijn artsexamen in 1976 een vervolg. Na een jaar chirurgie en verloskunde in het St.Jansgasthuis te Weert ter voorbereiding op het werk als tropenarts vertrok hij in 1977 voor een periode van 3 jaar naar Malawi. Bij terugkeer en twijfelend tussen chirurgie en huisartsgeneeskunde werkte hij een korte periode in Nordhorn, Duitsland, als assistent chirurgie, maar hij koos al snel voor het vak huisartsgeneeskunde. In 1982 vestigde hij zich als apotheekhoudend huisarts te Berg en Terblijt, een functie die hij tot 1998 uitoefende. Na een korte periode als bedrijfsarts te hebben gewerkt werd hij medisch adviseur bij CZ in Tilburg. In 2001 werkte hij mee aan de totstandkoming van "De Gezondheidslijn", een telefonische dienstverlening waar vragen over gezondheid worden beantwoord. Door dit werk kwam hij intensief in aanraking met het fenomeen telefonische triage. Dit boeide hem vanaf het eerste moment en werd de aanleiding van dit promotieonderzoek.

Hay Derkx was born on 24 September 1949 in Jakarta, Indonesia. After graduation from High school in 1968 he studied at the University of Nijmegen medical school. Following this he did a few internships in Tanzania. His interest in working in the tropics continued when he became a physician in 1976. In preparation for working in tropical medicine he was employed for one year as an intern at the surgical and gynaecological department at the St.Jansgasthuis in Weert. He then went to Malawi to work for 3 years at a mission hospital. On return to the Netherlands he worked in Nordhorn, Germany as an intern at the surgical department, but after a few months he decided to become a general practitioner. He worked as a general practitioner at Berg en Terblijt until 1998. After working for a short period of time as a company doctor he accepted a post at $\mathrm{CZ}$ in Tilburg, a Health Insurance Company. In 2001 he became involved in the development of "the Health line", a medical call centre. As a result of this experience he became increasingly fascinated by the phenomenon of telephone triage which resulted in this thesis. 


\section{Items of the RICE-communication rating list}

Name observer:

Name $\mathrm{OOH}$ :
Date of telephonecall:

Date of observation:

Items can be scored on a range of 0 untill 4

$0=$ absent $1=$ poor $2=$ unsure $3=$ adequate $\quad 4=$ good

$\mathrm{n} / \mathrm{a}=$ not applicable ( rightly absent)

\section{Communication skill per phase of consultation}

\section{Phase 1: Opening and global orientation on reason for calling}

(= problem, caller/patient experience, expectation, personal situation)

1. meeting by phone in an understandable way

a. gives own name understandable (introduces themselves)

b. mentions name of $\mathrm{OOH}$

2. asks for or names medical problem and the way this is experienced

a. asks for or names medical problem

b. seeks patients perspective

3. asks for or names expectation and personal situation

a. asks for or names expectation of caller

b. asks for or names personal situation of caller

4. asks about personal data at appropriate time and in an appropriate manner

01234

a. asks for personal data of caller after establishing reason for calling

b. announces this information will be asked

Phase 2: Collecting specified information about medical problem

5. asks preferably (semi) -closed questions

a. questions are preferably (semi)-closed

b. questions are understandable for caller

c. asks one question at a time

\section{Phase 3: Advice}

6. repeats medical problem and expectation, than gives course of action with explanation

a. repeats briefly problem and expectation of caller

b. gives suggested course of action with explanation

c. does not use technical jargon

7. checks whether caller has understood and can fulfil the proposal

a. checks whether the proposal is understood

b. check whether the proposal is feasible

8. discusses safetynet
a. tells what to do if present complaints worsen
b. tells what to do if caller remains worried
c. tells for which symptoms the caller should phone again 
Phase 4: Finishing the consultation

9. checks for agreement of caller with proposal

a. checks whether caller can agree with proposal

10. demonstrates open attitude and flexibility if caller disagrees

01234 n/a with proposal

a. shows open attitude if caller does not agree

b. goes into reason for disagreement

11. finishes consultation with correct closing remark

a. finishes consultation in professional way

b. let caller as first ring up the conversation

Phase of interruption: this may occur more than once during same call.

To be scored only once.

12. announces interruption in professional way and tells reason for this

a. announces interruption

b. tells reason for this interruption

13. resumes call in professional way and tells outcome of interruption

a. thanks for the waiting

b. tells outcome of interruption

\section{General communication skills}

14. summarizes, checks and corrects
a. gives summary
b. checks summary with caller
c. corrects summary if needed

15. reacts on feelings of caller after (non)-verbal signals
a. reacts on verbal signals
b. reacts on non-verbal signals'
c. gives feedback on own interpretation to caller

16. gives structure to conversation
a. links up different phases
b. announces next step of conversation

17. listens attentive
a. encourages caller with short signals to tell his/her story
b. confirms with short signals to have heard what the caller has told
c. addresses caller with his/her correct name
d. let caller finish his/her saying

Remaining feedback (free space for text) 


\section{HAAK-scorelijst}

Naam observator:

Beoordelingsdatum:

Code gesprek:

Beoordelingstijd:

De items worden gescoord op een schaal van $0 \mathrm{t} / \mathrm{m} 4$.

$0=$ niet aanwezig $1=$ slecht $\quad 2=$ twijfelachtig $3=$ voldoende $\quad 4=$ goed

nvt= niet van toepassing ( terecht afwezig)

\section{Communicatieve vaardigheden per gespreksfase}

Fase 1: Opening en globale vaststelling inbelvraag ( =probleem, beleving, verwachting en persoonlijke omstandigheden van beller)

1. Maakt telefonisch kennis op verstaanbare wijze

$O$ vermeldt eigen naam verstaanbaar

$O$ vermeldt naam huisartsenpost

2. Vraagt naar (medisch) probleem en de beleving hiervan

$O$ vraagt naar het (medische) probleem

O vraagt naar persoonlijke beleving hiervan

3. Vraagt naar de verwachting en de persoonlijke omstandigheden

$O$ vraagt naar de verwachting van de beller

$O$ vraagt naar zijn persoonlijke omstandigheden

4. Verzamelt persoonsgegevens op gepast moment

O neemt persoonsgegevens op na eerste oriëntatie op inbelvraag

\section{Fase 2: Verkrijgen van nadere informatie over het (medische) probleem}

5. Gebruikt bij voorkeur (semi) gesloten vragen

O stelt bij voorkeur semi (half) of geheel gesloten vragen

O stelt vragen op voor beller begrijpelijke wijze

\section{Fase 3 Vervolgbeleid}

6. Herhaalt probleem en hulpvraag,geeft dan vervolgbeleid met toelichting 01234 O herhaalt kort het probleem en de hulpvraag van de beller

O geeft vervolgbeleid aan met toelichting

O gebruikt geen vakjargon

7. Controleert of vervolgbeleid begrepen en uitvoerbaar is

$O$ controleert of vervolgbeleid begrepen is

O controleert of vervolgbeleid uitvoerbaar is

\section{Bespreekt vangnet}

$01234 \mathrm{nvt}$

$O$ vertelt wat te doen als huidige klachten verergeren

$O$ vertelt wat te doen als beller ongerust blijft

O vertelt bij welke nieuwe klachten opnieuw contact moet worden opgenomen 


\section{Fase 4: Afsluiten van het gesprek}

9. Controleert instemming van beller met vervolgbeleid

$\mathrm{O}$ controleert of beller kan instemmen met het vervolgbeleid

$01234 \mathrm{nvt}$

10. Toont open houding en flexibiliteit over vervolgbeleid

$\mathrm{O}$ toont open houding als beller niet instemt

$O$ verdiept zich in reden hiervan

11. Sluit af met correcte slotzin

O sluit gesprek op professionele wijze af

O laat beller als eerste de verbinding verbreken

\section{Onderbreking}

Tijdens het telefonische contact kan de centralist op ieder moment besluiten tot onderbreking.

Ook indien meerdere keren een onderbreking heeft plaatsgevonden tijdens hetzelfde contact, éénmaal scoren

12. Kondigt onderbreking professioneel aan en vermeldt de reden

$01234 \mathrm{nvt}$

O kondigt onderbreking aan

$O$ vertelt reden van onderbreking

13. Hervat gesprek professioneel en vertelt uitkomst van de onderbreking 01234 nvt O bedankt voor het wachten

O benoemt uitkomst van onderbreking

\section{Algemene communicatieve vaardigheden}

14. Samenvatten, controleren en bijstellen

O geeft samenvatting

O controleert samenvatting bij beller

O corrigeert zo nodig samenvatting

15. Reageert op gevoelens na (non-)verbale signalen

$O$ geeft reactie op verbale signalen

O geeft reactie op non-verbale signalen

O koppelt eigen interpretatie terug naar beller

16. Structureert het gesprek

01234

O laat de verschillende fasen op elkaar aansluiten

O kondigt volgende stap van gesprek aan

17. Luistert aandachtig

O moedigt beller met korte signalen aan zijn verhaal verder te vertellen

$O$ bevestigt met korte signalen dat hij gehoord heeft wat de beller vertelde

O noemt tijdens het gesprek de correcte naam van de beller

O laat beller uitpraten

Overige feedback ( vrije tekstruimte) 